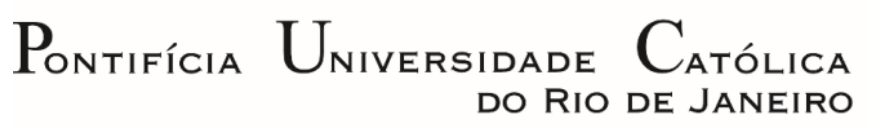

Luis Gustavo Costa Araújo

\title{
A MORTE FEITA DE PEDRA: \\ O MERCADO DE ESCRAVIZADOS DO VALONGO E \\ A NECROARQUITETURA
}

Dissertação apresentada como requisito parcial para obtenção do grau de Mestre em História pelo Programa de Pós-Graduação em História Social da Cultura da PUC-Rio.

Orientador: Prof. João Masao Kamita

Co-orientadora: Profa. Regiane Augusto de Mattos 


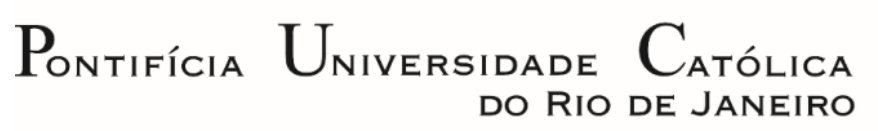

Luis Gustavo Costa Araújo

A MORTE FEITA DE PEDRA:

O MERCADO DE ESCRAVIZADOS DO VALONGO E

A NECROARQUITETURA

Dissertação apresentada como requisito parcial para obtenção do grau de Mestre pelo Programa de Pósgraduação em História Social da Cultura da PUCRio. Aprovada pela Comissão Examinadora abaixo assinada.

\author{
Prof. João Masao Kamita \\ Orientador \\ Departamento de História - PUC-Rio \\ Prof. Regiane Augusto de Mattos \\ Co-orientadora \\ Departamento de História - PUC-Rio
}

Prof. Mônica Lima e Souza

Instituto de História - UFRJ

Prof. Maria de Fátima Lima

Instituto de Medicina Social - UFRJ

Rio de Janeiro, 30 de maio de 2019 
Todos os direitos reservados. É proibida a reprodução total ou parcial do trabalho sem autorização da universidade, do autor e do orientador.

\section{Luis Gustavo Costa Araújo}

Arquiteto e Urbanista formado na UniSociesc em Joinville, Santa Catarina no ano de 2014. Desenvolve pesquisas na área de arquitetura, tendo como objeto principal as questões que tangem as relações étnico-raciais, suas manifestações no espaço físico/construído, necropolítica e necroarquitetura (conceito desenvolvido pelo pesquisador ao longo da dissertação). É membro da Comissão de Matriz Africana do Museu do Amanhã e também do Grupo de Estudos de História da África (GEHA), onde atualmente realiza estudos sobre as conexões culturais entre Moçambique e Rio de Janeiro.

Ficha Catalográfica

Araújo, Luis Gustavo Costa

A morte feita de pedra : o mercado de escravizados do Valongo e a necroarquitetura / Luis Gustavo Costa Araújo ; orientador: João Masao Kamita ; co-orientadora: Regiane Augusto de Mattos. - 2019.

160 f. : il. color. ; $30 \mathrm{~cm}$

Dissertação (mestrado) - Pontifícia Universidade Católica do Rio de Janeiro, Departamento de História, 2019.

Inclui bibliografia

1. História - Teses. 2. História Social da Cultura Teses. 3. Escravização. 4. Rio de Janeiro. 5. Valongo. 6. Necropolítica. 7. Necroarquitetura. I. Kamita, João Masao. II. Mattos, Regiane Augusto de. III. Pontifícia Universidade Católica do Rio de Janeiro. Departamento de História. IV. 
Aos que chegaram antes de mim e abriram os caminhos. 


\section{Agradecimentos}

Uma mulher negra, retirante nordestina, aos 23 anos de idade teve a coragem de assumir a responsabilidade de ser mãe solteira. À minha mãe, Maria do Socorro Costa Araújo, agradeço por ter me dado o mundo e me preparado para a vida com tanto amor, dedicação e carinho.

A Edson da Silva, o pai que escolhi pra mim, agradeço pela confiança e pelo carinho de sempre.

Ao meu companheiro e parceiro de vida, Plínio Filippi da Rocha Sampaio, minha gratidão pela paciência e por todo o apoio.

A Diogo Decker, por nunca me deixar esquecer que a vida é feita de lutas e superações, obrigado por sempre despertar o melhor de mim.

À minha amiga, Mayra Rodrigues Miranda, que apesar da distância sempre se fez presente, tornando a caminhada mais agradável e leve.

Às queridas, Ana Paula Jauregui, Ariadiny Brito, Camila Cagnato, Camila Muller, Karoline Fiorelli, Pamela Mansur e Rafaela Rodrigues, que seguem comigo e me ajudaram a dar passos anteriores, sem os quais eu não teria chegado até aqui.

Aos amigos Clarisse Rosa e Oséas de Olivera, agradeço a generosidade, o cuidado e o apoio incondicional no dia a dia e para além dele.

A Ademildes Freitas e Fábio Lucas, pela presença reconfortante, os momentos de alegria e felicidade que revigoram e alimentam a alma.

A David Alfredo, pela ajuda no meu despertar e por me ensinar tanto sem exigir nada em troca.

Agradeço ao meu professor orientador João Masao Kamita, por topar essa jornada desafiadora, pelas trocas e aprendizados.

À professora Regiane Augusto de Mattos, que hoje é muito mais que uma orientadora, por quem nutro uma admiração e um carinho que ultrapassam essas linhas.

Às professoras que participaram da Comissão examinadora.

A todos os professores, parceiros do GEHA (Grupo de Estudos de História da África) e funcionários do Departamento de História pelos ensinamentos e pela ajuda.

À Capes e à PUC-Rio, pelos auxílios concedidos, sem os quais este trabalho não poderia ter sido realizado. 


\section{Resumo}

Araújo, Luis Gustavo Costa; Kamita, João Masao; Mattos, Regiane Augusto de. A morte feita de pedra. 0 mercado de escravizados do Valongo e a necroarquitetura. Rio de Janeiro, 2019. 158p. Dissertação de Mestrado - Departamento de História, Pontifícia Universidade Católica do Rio de Janeiro.

Receber, triar, higienizar, armazenar, despachar, descartar. Esses eram alguns dos verbos usados para conjugar as milhares de vidas que chegavam nos ventres pútridos dos navios negreiros ao Brasil. Caso chegassem vivos, e se o seu destino fosse o porto do Rio de Janeiro, entre 1771 e 1833, os homens e mulheres africanos continuariam a sua trajetória de sobrevivência no mercado do Valongo, onde eram preparados e expostos à venda pública, - transformados em 'objeto, mercadoria e moeda' - negociados incansavelmente nos vários barracões espalhados pela bucólica vila de casinhas brancas com telhados vermelhos na freguesia de Santa Rita. Amparado por um sistema necropolítico que tinha a normatização da violência e a produção da morte, física e social, como modos de exercício da soberania, o Valongo constituiu-se espacialmente como um conjunto de equipamentos urbanos que funcionavam de modo integrado na tarefa de produção e distribuição da mão de obra escrava para diversas partes do continente. Tendo este cenário como ponto de partida, o presente trabalho se desenvolve como uma investigação dos processos sociais, políticos e culturais que conduziram a consolidação espacial do Valongo como um 'complexo comercial', buscando em sua expressão material e simbólica as bases para forjar um novo conceito que abarque a função necropolítica dos ambientes construídos: a necroarquitetura.

\section{Palavras-chave}

Escravização; Rio de Janeiro; Valongo; Necropolítica; Violência; Morte; Necroarquitetura. 


\section{Abstract}

Araújo, Luis Gustavo Costa; Kamita, João Masao (Advisor); Mattos, Regiane Augusto (Co-advisor). Death made of stone. The market of enslaved Valongo and the necroarchitecture. Rio de Janeiro, 2019. 158p. Dissertação de Mestrado - Departamento de História, Pontifícia Universidade Católica do Rio de Janeiro.

Receive, triage, sanitize, store, dispatch, discard. These were some of the verbs used to conjugate the thousands of lives that came in the putrid womb of the slave ships to Brazil. If they arrived alive, and if their destination was Rio de Janeiro's harbor, between 1771 and 1833, African men and women would continue their survival path in the Valongo market, where they were prepared and exposed to public sale, - transformed into 'object, commodity and currency' - tirelessly negotiated in the various barracks scattered in the bucolic village of white houses with red roofs in the parish of Santa Rita. The Valongo, supported by a necropolitic system that had the normatization of violence and the production of death, physical and social, as means of exercising sovereignty, constituted itself spatially as a set of urban equipment that functioned in an integrated way in the task of production and distribution of slave labor to various parts of the continent. Taking this scenario as a starting point, the present work develops as an investigation of the social, political and cultural processes that led the spatial consolidation of Valongo as a 'commercial complex', seeking in its material and symbolic expression the bases for forging a new concept that encompasses the necropolitic function of constructed environments: the necroarchitecture.

\section{Keywords}

Slavery; Rio de Janeiro; Necropolitc; Violence; Death; Necroarchitecture. 


\section{Sumário}

Introdução

1. Aqui tudo parece que era ainda construção e já é ruína

1.1. O Rio de Janeiro colonial, uma cartografia da segregação

1.2. O outro lado do espelho

2. O mercado de carne da carne do mundo

2.1. A materialização do erro 71

2.2. Programação da morte

3. Necroarquitetura: o poder pela estrutura

3.1. Materialidades necroarquitetônicas no Valongo 122

3.2. Necroarquitetura: uma máquina de matar 144

Considerações Finais 


\section{Lista de Figuras}

Figura 1. Desfile em fila indiana - Jean-Baptiste Debret (1813-1831) 49

Figura 2. Valongo - Thomas Ender (1818)

Figura 3. Valongo e os principais elementos do entorno

107

Figura 4. Trânsito dos cativos no Valongo - etapa 1

107

Figura 5. Trânsito dos cativos no Valongo - etapa 2

108

Figura 6. Trânsito dos cativos no Valongo - etapa 3

108

Figura 7. Mercado da Rua do Valongo 128

Figura 8. Valongo, ou mercado de escravos no Rio 140

Figura 9. O mercado de escravos - Henry Chamberlain (1820)

140 


\section{Lista de Quadros}

Quadro 1. Freguesias do Rio de Janeiro (séc. XVI a XIX) 28

Quadro 2. Crescimento demográfico do Rio de Janeiro 29

Quadro 3. Diagrama social Rio de Janeiro (1750 - 1870) 37 
"Chorei por tê-los odiado, Chorei por ainda ter mágoa dessa história."

Beatriz Nascimento

"E aquilo que nesse momento se revelará aos povos

Surpreenderá a todos não por ser exótico, Mas pelo fato de poder ter sempre estado oculto Quando terá sido o óbvio." 


\section{Introdução}

Era de Maria que a chamavam. Se este era seu nome verdadeiro não sabemos. Tinha 18 anos de idade e carregava em sua testa dois sinais, que poderiam ser identificações da sua nação Rebolo, ou indícios da sua condição de escravizada. Talvez estes sinais fossem marcas de nascença, assim como seus 'dentes abertos'. Já sobre o 'inchaço de carne' ao pé da garganta não é possível falar o mesmo, este por sua vez, era um retrato do corpo debilitado, violentado. É de se imaginar que, sobrevivendo em situação tão desumana, pouco restaria a alguém como Maria além de sua saia de chita e a camisa surrada que carregava consigo. Porém existe algo que a corrente não consegue prender, que o chicote não pode alcançar e nem a mordaça mais apertada pode conter. No dia 11 de novembro de 1830, no Jornal do Commércio do Rio de Janeiro, foi registrada a fuga de Maria do seu cativeiro no Valongo.

Ao longo dos mais de cinquenta anos de atividade (1774-1831) do maior mercado de escravizados de que se tem notícia em toda a história da humanidade - o complexo comercial do Valongo - são muitas as narrativas de fugas, resistências e sobrevivências por parte dos milhares de homens e mulheres negro-africanos que eram mantidos em cativeiro nos vários armazéns e depósitos que se espalhavam pela freguesia de Santa Rita, até então subúrbio da cidade do Rio de Janeiro. Estas vozes que ressoam das camadas subterrâneas da história, das quitandeiras nas ruas do porto, das casas de zungu na Saúde e na Providência, dos escravizados de ganho que enchiam os trapiches, enfim, da multidão negro-africana que povoava as ruas do Valongo, nos contam histórias de sobrevivência e de luta.

No entanto, ao longo das próximas páginas, adentraremos por outros caminhos, estes ainda menos luminosos. Será preciso percorrer o interior pútrido dos navios negreiros, passar pelos corpos amontoados nos armazéns e pelas chagas e cicatrizes camufladas no Lazareto da Gamboa, avistar a pilha de cadáveres semidecompostos no Cemitério dos Pretos Novos, seguindo o cheiro da morte cotidiana. Para o que se 
pretende construir (ou destruir) a partir deste trabalho será preciso olhar para os episódios fatais, de violência e dor. Não que eles sejam mais relevantes que as trajetórias de resistência dos negro-africanos, porém são momentos inescapáveis, que construíram as estruturas que aprisionam milhares de vidas ao longo dos séculos.

Este enclausuramento é fruto de incontáveis processos de efabulação que formularam um largo conjunto de discursos e práticas que balizaram a existência do sujeito negro-africano no interior das sociedades desde o primeiro momento da migração forçada do período colonial escravista até os dias de hoje. Ao conjunto de mecanismos e dispositivos de poder utilizados para produzir tal condição de subalternidade e precarização da vida, o pensador camaronês Achille Mbembe cunhou o termo necropolítica, que serve à presente pesquisa como ponto de partida para compreender como o espaço colonial se consolidava a partir da lógica de normatização da violência e produção da experiência de morte, física e social, dos sujeitos escravizados. É também a partir do pensamento de Mbembe que se torna visível a importância que a ação sobre o espaço, o ordenamento geográfico e arquitetônico do ambiente construído, possuía no interior dos projetos de dominação colonial. A segregação espacial e a criação de fronteiras visíveis e invisíveis eram necessárias para que fossem mantidas as interdições que separavam o mundo do 'ser' - branco-europeu, livre e civilizado - do mundo do 'não-ser' - negro-africano, escravizado e selvagem — fazendo emergir estruturas maniqueístas de divisão e organização, como também apontado pelo martinicano Frantz Fanon.

Deste modo, a reflexão aqui apresentada baseia-se na premissa de que o projeto colonial deixou marcas na pele, na sociedade e também nos espaços que foram ordenadamente arranjados para que a estrutura de opressão e dominação necessárias para garantir o status de soberania do colonizador se mantivessem cada vez mais sedimentados na terra em que dominavam e nos cérebros dos que eram dominados. Sendo assim, as técnicas de controle disciplinar e regulamentador foram largamente utilizadas em prol desse objetivo, incluindo-se nesse conjunto de saberes a arquitetura e o pensamento sobre o espaço construído. 
Estes pressupostos são fundamentais para a formulação da hipótese de que a arquitetura pode ser usada como dispositivo necropolítico de controle, produção e gestão da morte, adquirindo a forma do que está sendo conceituado aqui como necroarquitetura. É a partir destas perspectivas que iremos olhar para o Valongo como o local onde é possível identificar as características desta ação necropolítica e, consequentemente, da necroarquitetura.

Este percurso é dividido em três capítulos, que caracterizam etapas distintas, porém interligadas desta reflexão. O primeiro capítulo é dedicado à criação de um panorama sobre a história do Rio de Janeiro, da sua constituição urbana e seus processos sociais e políticos. Será considerado nesse primeiro momento o recorte temporal que vai desde a fundação da cidade no século XVI até a metade do século XIX. Esse recorte amplo visa abranger ao máximo as principais transformações que fizeram a ocupação colonial transformar-se na cidade sede do império português.

A criação do mercado do Valongo, nesse contexto de expansão da cidade aparece como uma vontade de parte dos interessados no comércio escravista muito antes de 1774 quando marquês de Lavradio define seus limites espaciais e continua sendo um local de grande representatividade mesmo depois de decretada a sua ilegalidade, visto a lei de 1830 que declarava ilegal o tráfico de escravizados. Desse modo, a temporalidade ampla está ligada ao reconhecimento da importância do Valongo como um elemento relevante dentro das transformações ocorridas na cidade.

Neste primeiro momento são também mobilizadas algumas fontes conceituais acerca da escravização como regime de poder e das suas manifestações no espaço físico. A ideia de 'mundo compartimentado' como apresentada por Frantz Fanon, é a espinha dorsal da construção dessa história do Rio de Janeiro, pautada sobre a perspectiva do ambiente colonial como um local de restrições para o escravizado, onde o seu mundo e o do soberano não são iguais, ainda que compartilhem o mesmo espaço físico. Também estarão nesse debate os pensamentos de Achille Mbembe em suas elaborações sobre a importância das ações 
soberanas que tem no espaço sua manifestação primordial, dentro das programações de poder necropolíticas. Na caracterização dos espaços que faziam parte do 'mundo do escravizado', na cidade do Rio de Janeiro, é utilizada basicamente a obra de Mary Karasch, que produziu uma larga pesquisa sobre a escravização urbana no Rio de Janeiro, contribuindo de modo significativo para essa e outras etapas da pesquisa.

No segundo capítulo seguiremos dentro dessa perspectiva histórica da estruturação urbana da cidade, porém focando especialmente no complexo comercial do Valongo. Entendendo que a existência do sujeito africano como escravizado tinha início no seu continente de origem, o capítulo inicia com uma passagem pelos principais modos de captura, distribuição e transporte das cargas humanas do tráfico negreiro. Até chegar ao mercado do Valongo o cativo já havia passado por vários estágios de violência, física e simbólica, que eram fundamentais para a criação da condição de subalternidade necessários para sua inserção como escravizado na sociedade que iria integrar.

Após esse momento introdutório será realizada uma análise da consolidação urbana do Valongo considerando duas dimensões: as leis e normativas produzidas pelo poder público e os relatos dos viajantes que passaram pelo local e registraram com suas palavras, e poucas imagens, as suas experiências no espaço, os aspectos físicos e a sua dinâmica de funcionamento. Recorreremos novamente nesse etapa ao trabalho de Karasch, principalmente por sua enorme contribuição, também serão fundamentais os escritos diversos de visitantes estrangeiros que deixaram relatos sobre sua passagem pelo Valongo, com destaque para os ingleses Maria Graham, em 1823, e C. Brand, em 1827, os alemães Carl Schlichthrost, em 1825, e G.W. Freyreiss, em 1815, o francês JeanBaptiste Debret, em 1816, o escocês John McDouall, em 1826.

Também são fontes importantes nesta etapa os documentos legais e mapas da época, conforme citado, sendo em sua grande maioria encontrados no Arquivo Nacional e no Arquivo da Cidade do Rio de Janeiro. Outra fonte que se mostrou fundamental para esta etapa é o Dossiê de Patrimonialização do Cais do Valongo, apresentado na candidatura do sítio arqueológico ao posto de Patrimônio Mundial da 
Humanidade à Unesco em 2016, produzido por uma equipe multidisciplinar de pesquisadores sob a coordenação do antropólogo Milton Guran.

Por fim, o terceiro capítulo destina-se a produzir as conexões entre todos os dados levantados sobre o Valongo e os conceitos que definem a necropolítica como um programa de poder operado no período de escravização de negro-africanos nas colônias europeias. É aqui também que serão lançadas as bases para que seja possível constatar a hipótese de que o espaço construído do Valongo era, acima de tudo, um dispositivo necropolítico, ou seja, tinha como principal objetivo operacionalizar os diagramas do necropoder. Para tal, inicialmente é realizada uma leitura mais atenta dos dois principais autores que conduzem o debate da bio e necropolítica, Michel Foucault e Achille Mbembe. Tendo lançadas essas bases teóricas, o capítulo segue para uma análise mais voltada às materialidades do espaço do Valongo, a fim de identificar em suas características a expressão do necropoder, o que os distinguem como necroarquitetura. Retomaremos os relatos dos viajantes, porém com maior atenção às descrições espaciais e os aspectos físicos de cada um dos equipamentos urbanos que constituíam o Valongo.

A discussão sobre a arquitetura como meios de efetivação de técnicas de controle e poder já foram alvo do debate de outros autores, como o já citado Michel Foucault e George Bataille. No entanto, assim como a necropolítica, a necroarquitetura difere de pressupostos já realizados por outros pensadores que se detiveram sobre esta temática e é neste debate que a última parte do terceiro capítulo está concentrada.

Em viés de conclusão, com essas reflexões acerca do Valongo, poderemos pensar com mais complexidade na possibilidade da existência de uma necroarquitetura, ou seja, espaços que são fruto do cálculo sobre a vida, mas que têm por objetivo produzir a morte de seres humanos, mediante a transformação da violência na norma de disciplina e regulamentação dos corpos e subjetividades. A utilização de técnicas de ordenamento espacial, $\mathrm{O}$ ato de projetar e construir edificações, a sistematização e a programação das ações realizadas no Valongo; todos 
são tópicos que demonstram como tais conhecimentos e saberes serviram a esse objetivo funesto e cruel, reforçando seu caráter genocida. O mercado do Valongo apresenta-se assim como a oportunidade de realizar as averiguações das especificidades arquitetônicas dessas materializações necropolíticas dentro da sua lógica de funcionamento e operação. 


\section{Aqui tudo parece que era ainda construção e já é ruína}

A cidade de São Sebastião do Rio de Janeiro, quando vista através de sua entrada pela Baía de Guanabara, parecia uma aldeia bucólica de casas brancas e telhados laranjas em que a paisagem construída em contraste com a beleza natural causava enorme fascínio nos viajantes que chegaram entre os séculos XVIII e XIX. Um corpo negro está atado ao tronco, em plena praça pública, um nó forte prende o seu pulso ao pilar de madeira forçando seu corpo para que fique em uma posição onde suas costas possam estar totalmente expostas para receber o golpe; a primeira chibatada corta o ar e arde na pele. Até meados do século XIX a cidade do Rio de Janeiro concentrava-se, quase em sua totalidade, no espaço formado entre os Morros do Castelo, de São Bento, de Santo Antônio e da Conceição, tendo ainda como limites o mangue de São Diogo e a Baía de Guanabara. Mais dez, vinte, trinta, quarenta golpes de chicote; o corpo sangra, a mente delira, os olhos apertados de dor captam as feições de horror e sofrimento dos que aguardam a sua vez ao tronco. Além das belezas naturais outro fator de grande proeminência na paisagem carioca era a forte presença dos signos da fé cristã, que materializavam-se em larga escala nas igrejas, monumentos e santuários religiosos que ocupavam desde 0 alto dos morros até as freguesias mais afastadas. Cem, duzentas, trezentas chibatadas e o corpo negro violentado é por fim libertado do pelourinho. Largado à sorte em meio aos outros negros, uma mulher segura o corpo ferido, derramando lágrimas sobre as suas chagas; poderíamos nos servir da clássica cena da Pietá para ilustrar esse momento de profunda tristeza e luto, porém como diz Mbembe (2016) 'nem todos os crimes são sagrados', mesmo quando cometidos no campo santo.

Os golpes rasgam a pele, atingem a carne e fazem a consciência vacilar. Criam sulcos que, com o tempo, serão transformados em cicatrizes ou em memórias. Porém, algumas feridas ficam abertas, e permanecem até hoje purulentas. Marcas desses corpos negro-africanos mutilados podem ser encontradas nas ruas, nos monumentos, nas calçadas e casas. Assim como o sangue que respinga e salpica tudo 0 
que encosta, o sistema escravista manchou para sempre as cidades e os espaços que serviram de palco para as atrocidades cometidas em prol do acúmulo de riquezas e de bens materiais das grandes elites soberanas.

De acordo com Nascimento (2017),

O papel do negro escravo foi decisivo para o começo da história econômica de um país fundado, como era o caso do Brasil, sob o signo do parasitas imperialista. Sem o escravo, a estrutura econômica do país jamais teria existido. O africano escravizado construiu as fundações da nova sociedade com a flexão e a quebra da sua espinha dorsal, quando ao mesmo tempo seu trabalho significava a própria espinha dorsal daquela colônia. Ele plantou, alimentou e colheu a riqueza material do país para o desfrute exclusivo da aristocracia branca. Tanto nas plantações de cana-de-açúcar e café e na mineração, quanto nas cidades, o africano incorporava as mãos e os pés das classes dirigentes que não se autodegradavam em ocupações vis como aquelas do trabalho braçal. A notabilizaste ocupação das classes dirigentes - os latifundiários, os comerciantes, os sacerdotes católicos consistia no exercício da indolência, no cultivo da ignorância, do preconceito, e na prática da mais licenciosa luxúria. (NASCIMENTO, 2017, p.59)

O Rio de Janeiro, sendo uma das mais importantes cidades da colônia portuguesa no Brasil, está até hoje tendo que tratar dos seus ferimentos que insistem em macular as imagens do paraíso tropical e verdejante que ainda fazem parte do imaginário de muitos. Mesmo com a insistente tentativa de apagamento ou de sublimação dessa presença indesejada, mesmo que necessária, a existência dos negro-africanos escravizados na cidade é indissociável de qualquer narrativa sobre o seu período colonial.

Conforme relatado por Karasch (2000),

Na primeira metade do século XIX, o testemunho dos viajantes revela que o Rio era único não só por sua beleza natural, mas também por sua grande população africana escrava. Os dois elementos eram inseparáveis da atmosfera da cidade; contudo, o que os historiadores e estudiosos do passado têm escolhido lembrar sobre o Rio é sua beleza perdida, agora transformada em arranha-céus de vidro e avenidas congestionadas de carros.

(KARASCH, 2000, p. 19)

De fato a presença física do negro-africano na cidade carioca era algo notável, desde o século XVII. Se um viajante chegasse pelo largo da Baía de Guanabara, por exemplo, seria seguido desde o desembarque até o seu destino, seja ele qual fosse, pela constante figura do negro- 
africano escravizado. Os rostos cheios de cicatrizes, os olhares apáticos, os dentes limados, as roupas de estilo africano, os corpos fragilizados; muitos eram os elementos que podiam fazer o cidadão acreditar ter recém-chegado no próprio continente africano ${ }^{1}$.

Mesmo que o corpo negro-africano estivesse exposto de forma massiva pelas ruas - Karasch (2000, p.28) afirma que "entre os anos de 1808 a 1850 o Rio de Janeiro teve a maior população escravizada urbana das Américas, somando quase 80 mil pessoas em 1849" - , a sua humanidade não configurava uma relação de similitude com a soberania, pelo contrário, a sua existência estava atrelada à condição de 'homemobjeto, homem-mercadoria e homem-moeda' (Mbembe, 2014, p.12). Sendo então objeto, mercadoria e moeda, o escravizado passava a pertencer a 'alguém'. Sua vida estava ligada diretamente a de outra pessoa que exercia poder sobre o seu corpo, trocava o seu nome, renegava a sua língua, extraía sua força de trabalho até a exaustão, 'mas com quem era interdito ter relações co-humanas' (Mbembe, 2014, p. 12).

Os soberanos e os escravizados ocupavam mundos distintos. Conforme podemos observar em Fanon (1968),

\begin{abstract}
A zona habitada pelos colonizados não é complementar da zona habitada pelos colonos. Essas duas zonas opõem-se, mas não ao serviço de uma unidade superior. Regidas por uma lógica puramente aristotélica, obedecem ao princípio da exclusão recíproca: não há conciliação possível, um dos termos está a mais.

(FANON, 1968, p. 28)
\end{abstract}

Ainda que os pés descalços dos negro-africanos tocassem o solo por onde pisaram as botas dos seus senhores, ambos não estavam trilhando o mesmo caminho. O espaço colonial era pensado e construído para que essa diferença fosse claramente delimitada e visível, garantindo total controle físico e geográfico a quem detinha o poder sobre o território, onde um novo programa de relações sociais e espaciais passaria a funcionar dependendo da sua vontade e intenções. A interdição, que estava no cerne da relação entre o escravizado e o seu senhor,

\footnotetext{
1“(...) em especial no calor do meio-dia, quando os brancos desertavam das ruas, os estrangeiros sentiam com frequência que não tinham desembarcado na capital do Brasil, mas na África". (KARASCH. 2000, p.20)
} 
materializava-se no espaço físico. Era o exercício da demarcação territorial, a criação de limites, de fronteiras e imaginários, que asseguravam a instituição de direitos distintos para grupos que ocupavam um mesmo espaço; 'em resumo, o exercício da soberania'.

Esse 'mundo estreito e cheio de interdições', relatado por Fanon (1968, p.27) era a essência da própria vida do escravizado, tornada pedra e barro, levantando-se como paredes e telhados, criando o seu cativeiro. A redução do negro-africano à condição de escravizado era resultado de uma tripla perda que ocorria assim que o cativo adentrava o mundo colonial, aonde

(...) no contexto da colonização, figura-se a natureza humana do escravo como uma sombra personificada. De fato, a condição de escravo resulta de uma tripla perda: perda de um 'lar', perda de direitos sobre seu corpo e perda de status político. Essa perda tripla equivale a dominação absoluta, alienação ao nascer e morte social (expulsão da humanidade de modo geral). (MBEMBE, 2016, p. 136)

Fosse na fazenda, ou na cidade, o espaço colonial tinha como meta garantir a condição objetal do negro-africano escravizado para que a partir desse lugar de desumanidade absoluta o controle sobre o seu corpo e mente ocorresse da forma mais completa possível. Tendo em mãos essas formas, a soberania carioca passava a construir uma cidade que garantisse a sua segurança e conforto, recolhendo em suas entranhas os horrores do escravismo ao longo de séculos. Conjugando numa mesma cidade o espaço sólido, abundante, luxurioso e cheio de privilégios que pertenciam ao colono em contradição com o mundo esfomeado, necessitado, machucado e violentado dos que eram mantidos em cativeiro.

Se observarmos pela perspectiva de um senhor escravocrata, o Rio de Janeiro era o local adequado para suas necessidades. De um lado protegido das tempestades e dos ataques marinhos pela plácida Baía de Guanabara, por outro repleto de fortificações e montanhas que o guardavam por terra. Já do ponto de vista dos escravizados restavam-Ihe

\footnotetext{
2 "O espaço era, portanto, a matéria-prima da soberania e da violência que sustentava. Soberania significa ocupação, e ocupação significa relegar o colonizado em uma terceira zona, entre o status de sujeito e objeto." (MBEMBE. 2016, p.135)
} 
os limites, as barreiras físicas e sociais que o afastavam da sua liberdade (Karasch, 2000). Quanto mais claras as diferenças estivessem a olhos nus, mais assegurada estava a estratégia de dominação escravista, por isso a compartimentação do mundo colonial tinha o compromisso de 'deixar visíveis as realidades humanas' (Fanon, 1960, p.29).

Visto que o espaço colonial tinha como principal critério de organização a cisão entre o ambiente destinado a soberania e o universo limitado do escravizado, a lâmina que provoca essa incisão era a raça. Fanon afirma,

Quando se compreende no seu aspecto imediato o contexto colonial, é evidente que o que divide o mundo é sobretudo o fato de se pertencer ou não a tal espécie, a tal raça. Nas colônias, a infraestrutura é igualmente uma superestrutura. A causa é efeito: se é rico porque é branco, se é branco porque é rico.

(FANON, 1960, p. 29)

O corte realizado cirurgicamente pela intelectualidade europeia, que se constitui como a hegemonia do pensamento ocidental e o manual de instruções do sistema escravista a partir do século XVIII, teve como principal movimento a elaboração ostensiva da fábula da superioridade racial para justificar as atrocidades cometidas contra o continente africano.

Antes de mais, a raça não existe enquanto fato natural físico, antropológico ou genético. A raça não passa de uma ficção útil, de uma construção fantasiada ou de uma projeção ideológica (...) Em muitos casos é uma figura autônoma do real, cuja força e densidade podem explicar-se pelo seu caráter extremamente móvel, inconstante e caprichoso. Aliás ainda há bem pouco tempo, a ordem do mundo fundava-se num dualismo inaugural que encontrava parte das suas justificativas no velho mito da superioridade racial. $\mathrm{Na}$ sua ávida necessidade de mitos destinados a fundamentar o seu poder, o hemisfério ocidental considerava-se o centro do globo, o país natal da razão, da vida universal e da verdade da humanidade (...) o bairro mais civilizado do mundo.

(MBEMBE, 2014, p.27)

Esse cesura realizada a sangue frio, trancafiou o negro-africano nas profundezas do calabouço da humanidade. Aprisionados na escuridão, tendo que lidar eternamente com o fardo de um primitivismo nato. Mbembe (2014) observa que

Hegel dizia, a propósito de tais figuras [os negros] que eles eram estátuas sem linguagem nem consciência de si; entidades humanas incapazes de se despir de vez da figura 
animal com que estavam misturadas. No fundo, era da sua natureza albergar o que estava morto.

(MBEMBE, 2014, p.28)

O africano aos olhos da filosofia e do pensamento europeu, que inauguraram seus estudos de catalogação das espécies humanas em conjunto com a dominação escravista, só conseguia ser visto dentro de duas perspectivas: o 'selvagem' que precisava ser atacado e domado ou o 'ser inferior' que precisava de ajuda para despertar sua humanidade adormecida. Ao longo deste processo,

\begin{abstract}
(...) no decorrer do período Atlântico esta pequena província do planeta que é a Europa inscreve-se progressivamente numa posição de comando do resto do mundo. Paralelamente, ao longo do século XVIII, surgem vários discursos sinceros acerca da natureza, da especificidade e das formas dos seres vivos, das qualidades, traços e características dos seres humanos e, até de populações inteiras, que são especificadas em termos de espécies, gêneros ou raças classificados ao longo de uma linha vertical. Paradoxalmente, é também a época na qual as pessoas $e$ as culturas começam a ser consideradas individualizas em si mesmas. (MBEMBE, 2014, p.38)
\end{abstract}

Estes movimentos de conquista e dominação tornaram o negroafricano condenado a viver uma humanidade inacabada, que só por intermédio do contato com o branco-europeu poderia encontrar algum sentido, mesmo que fosse a escravização eterna (Mbembe, 2014, p.42).

Atuando paralelamente como os jogadores mais fortes e os criadores do próprio jogo, a soberania branco-europeia passa a controlar os espaços e também impossibilitar o negro-africano de constituir um discurso de autodefinição dentro desse cenário predatório e assimétrico da conquista colonial. Essa impossibilidade de desenvolvimento de uma experiência autônoma estava apoiada na estratégia de controle e dominação do espaço por parte do colonizador. Porém, além da impossibilidade de uma relação livre entre o escravizado e o espaço que o cercava, a ação colonial também dificultava a criação de um esquema corporal próprio do cativo, dentro dos espaços de dominação. Para Fanon (2008),

No mundo branco, o homem de cor encontra dificuldades na elaboração de seu esquema corporal. O conhecimento do corpo é unicamente uma atividade de negação. É um conhecimento em terceira pessoa. Em torno do corpo reina uma atmosfera densa de incertezas.

(FANON, 2008, p.104) 
Essa estratégia era de extrema importância para os senhores de escravizados, visto que a fábula de uma existência inacabada era o que justificava grande parte das violências praticadas dentro da colônia. Aterrorizado pela angústia de se ver agrilhoado a uma existência que não encontra sentido em si mesma, apenas com relação ao outro, o escravizado permanecia sempre em estado de alerta. Fanon (1960, p.39) afirma que,

O colonizado está sempre alerta, decifrando dificilmente os múltiplos signos do mundo colonial; nunca se sabe se passou ou não o limite. Frente ao mundo determinado pelo colonialista, o colonizado presume-se sempre culpado.

(FANON, 1960, p.39)

Ao negro-africano era sempre exigido uma adaptação, uma transformação, uma adequação, que podia ser de natureza cultural, física ou simbólica, ou seja, eram 'seres em eterna mutação' (Mbembe, 2014, p.19). Nesse estado de constante atenção, o cativo era mantido sob um regime de terror e violência que paralisava seu corpo, contraía seus músculos e mantinha o poder nas mãos do soberano.

A partir dessa lógica de sujeição, o escravizado ocupava um lugar intermediário dentro da estrutura social da colônia, era algo que precisava existir para que a economia e as engrenagens da máquina colonial continuassem rodando, porém ele não era visto como um ser humano acabado, ou pelo menos digno de ser reconhecido como tal, era o 'sujo, mas desejável' (Kilomba, 2010, p.174).

A segregação espacial com base na estratificação social está no DNA das cidades coloniais, como visto até o momento, no caso do Rio de Janeiro que concentrava um número expressivo de escravizados em seu território. Tais traços genéticos ficam ainda mais evidentes e perduram até os dias de hoje, como afirma Abreu

(...) o alto grau de estratificação social do espaço metropolitano do Rio de Janeiro, na atualidade, é apenas a expressão mais acabada e um processo de segregação das classes populares que vem se desenvolvendo no Rio há bastante tempo. (ABREU, 1987, p.9)

A ocupação da cidade no período colonial seguiu categoricamente essa fórmula, produzindo mundos diferentes dentro do mesmo espaço, 
mundos criados através de barreiras físicas e simbólicas. O rompimento dessas barreiras exigia força e resistência, e muitas delas de fato eram intransponíveis. Contudo, mesmo ocupando a parte mais desfavorecida do mundo onde estava aprisionado, o escravizado produzia 'compreensões alternativas sobre o tempo, sobre o trabalho e sobre si mesmo' (Mbembe, 2016, p.132). Talvez fosse essa capacidade de sobreviver e o sonho da liberdade, mesmo quando a resistência significava a aniquilação, que levava diversos homens e mulheres a fugir desse mundo de sujeição.

Uma das formas de escapar dessa masmorra era procurar abrigo nas florestas e montanhas em torno da área urbana da cidade, onde os escravizados que escapavam podiam viver livres do poder cruel da soberania, porém ainda eram prisioneiros de sua própria pele.

\subsection{O Rio de Janeiro colonial, uma cartografia da segregação}

O processo de escravização no Brasil operou suas técnicas e dispositivos de controle e coerção de corpos e mentes, em prol da exploração dos povos negro-africanos escravizados entre os séculos XV e XIX. Abdias Nascimento aponta a presença de negros escravizados logo no início do século XVI em terras brasileiras, segundo ele:

\footnotetext{
Por volta de 1530 , os africanos, trazidos sob correntes, já aprecem exercendo seu papel de 'força de trabalho'; em 1535 o comércio escravo para o Brasil estava regularmente constituído e organizado, e rapidamente aumentaria em proporções enormes. (NASCIMENTO, 2017, p.59)
}

Enquanto a Europa expandia seu território além-mar, com as grandes navegações e a subsequente colonização dos territórios 'descobertos' nesse movimento de exploração das fronteiras do planeta Terra, o continente africano tornou-se a fonte de mão de obra para a construção de um império europeu fora das fronteiras geográficas do continente, onde a soberania colheu durante séculos os frutos que foram cultivados nas terras regadas pelo sangue de homens e mulheres negroafricanos explorados de forma ostensiva e desumana pela máquina escravista colonial. 
Inserido nesse contexto a cidade do Rio de Janeiro figurava como um dos mais importantes entrepostos comerciais (Honorato, 2008), tornando-se inclusive sede do império português entre os anos de 1808 a 1821. As próximas páginas irão tratar sobre a constituição urbana da cidade do Rio de Janeiro no período colonial, atendo-se às questões de formação do espaço construído e na sua capacidade de refletir as relações de poder que operavam em seu território.

As terras do Rio de Janeiro representavam um verdadeiro refúgio para os recém-chegados. Por um lado, a baía e o litoral recortado que separava a cidade do mar aberto, de outro as montanhas e encostas que permitiam a criação de postos de controle e fortificações. Nesse cenário altamente privilegiado, dentro do contexto das conquistas coloniais, fundou-se em 1567 a cidade de São Sebastião do Rio de Janeiro. Ao longo dos anos a cidade desenvolveu-se através da atividade portuária, que se tornou responsável pelo recebimento e distribuição dos produtos considerados mais importantes da história do Brasil colônia: açúcar, ouro e café (Andreatta, 2006).

A forte relação entre o espaço construído e a natureza marca a história do processo de evolução do Rio de Janeiro. Mesmo sendo altamente propícia para as atividades portuárias e de fortificação, a cidade apresentava um território de difícil ocupação e que exigiu intervenções drásticas na paisagem. Sendo assim, (...) esta característica distingue o Rio de Janeiro porque as
operações de transformações de seu território podem ser
adjetivadas como desproporcionais em relação àquelas
levadas a cabo em qualquer outra cidade. A partir da pequena
fortaleza natural da colonização portuguesa, a ação de
urbanização permitiu ocupar um território pouco propenso a
isso, com operações que acabaram com quase todos os
morros limítrofes, transformaram a maioria das suas praias
urbanas, perfuraram túneis, e ademais incluíram a plantação
artificial da sua floresta tropical e o resultado foi de tal ordem
que, paradoxalmente, a cidade é tida como exemplo de
adaptação à natureza, e não como realmente é: natureza
construída.

(ANDREATTA, 2006, p.20)

A partir de trais transformações, que se iniciam no século XVIII e desenrolaram-se por mais dois séculos, a área urbana que desde o fim do $\mathrm{XVI}$ concentrava-se em uma pequena área de $0,5 \mathrm{~km}^{2}$, apertada entre os 
Morros do Castelo e Santo Antônio, a Praia do Peixe e a Rua da Quitanda desenvolve-se em uma progressão geométrica que duplicava a sua superfície ocupada a cada dezessete anos (Andreatta, 2006).

Os limites naturais que condicionavam a forma da cidade incluíam também, ao norte os morros de São Bento e Conceição que prosseguiam, formando uma cadeia de montanhas, juntamente com os morros da Providência, Pinto e São Diogo; ao sul, o já citado morro do Castelo uniase ao do Senado, Paula Matos e Santos Rodrigues, que configuram a parte final da Serra da Carioca. No interior de toda essa formação rochosa estava uma grande área pantanosa, repleta de lagoas e rios, que alimentavam o saco de São Diogo que, por sua vez, estava conectado com o mar pela Bica dos Marinheiros. O saco de São Diogo, por sua vez, compreendia

(...) aproximadamente, a área formada na atualidade pelas margens do canal do mangue (ocupados pelo Gasômetro, a estação Leopoldina, a Rodoviária Novo Rio e as instalações da Companhia Docas), o Trevo das Forças Armadas, a Avenida Presidente Vargas até a Praça Onze e as zonas onde estão hoje as instalações do metrô e ferroviárias, até a borda do morro do Pinto. (ANDREATTA, 2006, p.25)

Todo esse sistema hídrico estava ligado ao mangue de São Diogo (atual Cidade Nova), que se prolongava pelos alagadiços de Pedro Dias e seguiam (...) encaixados entre os morros Santo Antônio, Santa Tereza e
do Senado, até perto da cidade. Nesse espaço eram
abundantes as lagoas, sendo as mais importantes a de
Sentinela (entre a Rua de Santana e o atual Sambódromo), a
do Desterro (entre a Praça Tiradentes e a Avenida Mem de
Sá), a da Pavuna (entre o Largo São Francisco e do metrô
Uruguaiana), a de Santo Antônio (do Largo da Carioca ao
Teatro Municipal e, já na cosa, a do Boqueirão (onde está o
Passei Público, na Lapa).

(ANDREATTA, 2006, p.25)

O mar adentrava de forma substancial o continente, na verdade 0 mar esteve sempre ligado à cidade. Fosse pelas águas que estavam no interior do território ou pelas diversas enseadas que se espalhavam pelo litoral recortado, com destaque para os sacos do Valongo, da Gamboa e dos Alferes (Honorato, 2006). Essa profusão de brejos e manguezais eram vistos por parte dos especialistas em saúde, e também pelas 
autoridades, como um dos grandes responsáveis pela insalubridade e doenças que assolavam o ambiente carioca.

Em busca da solução desses, e de outros problemas, foi que a Câmara Municipal decidiu em 1850 intensificar as obras para o aterro do Saco de São Diogo, promovendo não só a melhoria das condições de vida dentro da cidade, como também a expansão e a criação de novas freguesias. Porém, antes do aterro do Saco de São Diogo, no século XVIII (...) começaram as operações de dessecação dos pântanos e
manguezais situados no interior, a oeste da cidade. Quando a
corte portuguesa se transferiu para o Rio de Janeiro, já haviam
desaparecido algumas dessas lagoas e uma boa parte do
mangue; em 1712 abriu-se uma rua provavelmente a atual rua
13 de Maio, no meio da lagoa de Santo Antônio, edificando-se
nas suas margens ao longo do século; o aterro do Alagadiço de
Pedro Dias se produz entre 1769 e 1779 ; e a lagoa do
Boqueirão foi terraplenada em 1780 com as terras do
desmonte do Morro das Mangueiras, e nela se construiu o
Passeio Público.
(ANDREATTA, 2006, p. 26)

Na fundação da cidade pela provisão 20 de fevereiro de 1569 criase a primeira freguesia do Rio de Janeiro, a de São Sebastião. Conforme a população aumentava o território da cidade também expandia-se e com isso novas freguesias eram criadas para abarcar a demanda. No ano de 1753 a área urbana dividia-se em duas freguesias, Sé e Candelária, sendo criadas duas novas nesse mesmo ano, a de Santa Rita e São José. As demais freguesias existentes nesse período localizavam-se na área rural. A divisão territorial em freguesias tinha duas funções durante 0 período colonial, religiosa e administrativa, somando-se 21 ao fim do período monárquico (Santos, 1965).

Quadro 1. Freguesias do Rio de Janeiro (séc. XVI a XIX)

\begin{tabular}{|l|l|l|l|}
\hline \multicolumn{2}{|c|}{ Quadro 1 - Freguesias do Rio de Janeiro (século XVI a XIX) e suas datas de } \\
Freguesia & $\begin{array}{c}\text { Ano de } \\
\text { fundação }\end{array}$ & \multicolumn{1}{|c|}{ Freguesia } & \multicolumn{1}{|c|}{ Ano de fundação } \\
\hline São Sebastião & 1569 & $\begin{array}{l}\text { llha de } \\
\text { Paquetá }\end{array}$ & 1769 \\
\hline Candelária & 1634 & Lagoa & 1809 \\
\hline Irajá & 1644 & Santana & 1814 \\
\hline Jacarepaguá & 1661 & Sacramento & 1826 - substituindo São \\
\hline
\end{tabular}




\begin{tabular}{|c|c|c|c|}
\hline \multirow[b]{2}{*}{ Campo Grande } & \multirow[b]{2}{*}{1673} & \multirow[b]{2}{*}{ Santa Cruz } & Sebastião \\
\hline & & & 1833 \\
\hline \multirow{2}{*}{$\begin{array}{l}\text { Ilha do Governador } \\
\text { Inhaúma }\end{array}$} & 1710 & \multirow{2}{*}{$\begin{array}{l}\text { Glória } \\
\text { Santo Antônio }\end{array}$} & 1834 \\
\hline & 1749 & & 1854 \\
\hline São José & 1751 & São Cristóvão & 1856 \\
\hline Santa Rita & 1751 & Espírito Santo & 1865 \\
\hline \multirow{2}{*}{$\begin{array}{l}\text { Guaratiba } \\
\text { Engenho Velho }\end{array}$} & 1755 & \multirow{2}{*}{$\begin{array}{l}\text { Engenho Novo } \\
\text { Gávea }\end{array}$} & 1873 \\
\hline & 1762 & & 1873 \\
\hline
\end{tabular}

Fonte: SANTOS, 1965.

Mesmo após a chegada da família real, e já muito próximo da independência do país, o Rio de Janeiro permanece uma cidade modesta. Em 1821 o território ainda limitava-se basicamente às freguesias da Candelária, São José, Sacramento, Santa Rita e Santana, que atualmente correspondem grosso modo, às atuais regiões administrativas do Centro e Portuária, sendo as demais freguesias ainda predominantemente rurais (Abreu, 1987). As freguesias urbanas, concentravam as maiores taxas populacionais, somando em $1821 \mathrm{um}$ total de 79.321 habitantes. Considerando que o somatório de habitantes de todas as freguesias, urbanas e rurais, era de 112.695 pessoas, os números demonstram que até 1870 essa distribuição populacional manteve-se. Inclusive as taxas de crescimento demográfico apontam um crescimento maior nas regiões urbanas nos dois períodos levantados, conforme quadro abaixo.

Quadro 2. População residente e taxa de crescimento demográfico do Rio de Janeiro

\begin{tabular}{|c|c|c|c|c|c|}
\hline \multirow[t]{2}{*}{ Freguesias } & \multicolumn{3}{|c|}{ População Residente } & \multicolumn{2}{|c|}{ Taxas de Crescimento } \\
\hline & 1821 & 1838 & 1870 & $1821-1838$ & $1838-1870$ \\
\hline $\begin{array}{l}\text { Freguesias } \\
\text { Urbanas }\end{array}$ & 79.321 & 97.162 & 191.002 & 22 & 97 \\
\hline Candelária & 12.445 & 10.113 & 9.239 & -19 & -9 \\
\hline São José & 19.881 & 14.410 & 9.239 & -27 & 40 \\
\hline Sta. Rita & 13.744 & 14.557 & 23.810 & 6 & 64 \\
\hline
\end{tabular}




\begin{tabular}{|c|c|c|c|c|c|}
\hline \multicolumn{6}{|c|}{$\begin{array}{c}\text { Quadro } 2 \text { - População Residente e Taxa de Crescimento Demográfico do Rio de } \\
\text { Janeiro (1821/1838/1870) }\end{array}$} \\
\hline \multirow[t]{2}{*}{ Freguesias } & \multicolumn{3}{|c|}{ População Residente } & \multicolumn{2}{|c|}{ Taxas de Crescimento } \\
\hline & 1821 & 1838 & 1870 & $1821-1838$ & $1838-1870$ \\
\hline Sacramento & 22.486 & 24.256 & 24.429 & 8 & 1 \\
\hline Glória & - & 6.568 & 18.624 & - & 184 \\
\hline Santana & 10.835 & 15.773 & 32.686 & 46 & 107 \\
\hline Sto. Antônio & - & - & 17.427 & - & - \\
\hline Espírito Santo & - & - & 10.796 & - & - \\
\hline Eng. Velho & 4.877 & 8.166 & 13.195 & 67 & 62 \\
\hline Lagoa & 2.125 & 3.319 & 11.304 & 56 & 241 \\
\hline São Cristóvão & - & - & 9.272 & - & - \\
\hline Gávea & - & - & - & - & - \\
\hline Eng. Novo & - & - & - & - & - \\
\hline $\begin{array}{l}\text { Freguesias } \\
\text { Rurais }\end{array}$ & 33.374 & 39.916 & 44.289 & 20 & 11 \\
\hline Irajá & 3.757 & 5.034 & 5.746 & 34 & 14 \\
\hline Jacarepaguá & 5.841 & 7.302 & 7.633 & 25 & 5 \\
\hline Inhaúma & 2.840 & 3.091 & 7.190 & 9 & 133 \\
\hline Guaratiba & 5.434 & 9.385 & 6.918 & 73 & -26 \\
\hline Campo Grande & 5.628 & 7.519 & 9.593 & 34 & 27 \\
\hline Sta. Cruz & - & 3.677 & 3.445 & - & -6 \\
\hline $\begin{array}{l}\text { Ilha do } \\
\text { Governador }\end{array}$ & 1.695 & 2.391 & 2.504 & 41 & 5 \\
\hline Ilha de Paquetá & 1.177 & 1517 & 1260 & 29 & 17 \\
\hline Total & 112.695 & 137.078 & 235.291 & 22 & 72 \\
\hline
\end{tabular}

Fonte: SANTOS, 1965.

Toda essa população das áreas urbanas vivia em uma cidade altamente adensada, visto a pouca porção de terra apropriada para a construção. Um passeio pelas ruas do Rio de Janeiro colonial poderia ser bem mais desagradável do que faz parecer a visão paradisíaca constantemente relatada pelos que chegavam pela baía. Como exemplo temos os escritos de Jaime L. Bechimol, 
(...) um dos autores que com mais precisão estudaram a evolução urbana do Rio de Janeiro no século XIV, descreve as condições da vida nessa cidade através das opiniões que transmitem os escritos de viajantes da época, como as de G. Gardner em Travels in the interior of Brasil, de 1831: 'Vista de bordo a cidade apresenta um aspecto imponente por sua posição e por suas numerosas igrejas caiadas de branco. Mas, olhada de perto, desvanece-se a ilusão. Quem quer que entre nessa cidade que, cintilante de longe parece celestial, desconsolado errará em meio a tanta coisa repugnante e mesquinha'.

(ANDREATTA, 2006, p.86)

A maioria das casas da área urbana eram baixas - com no máximo dois andares - caiadas de branco, cobertas de telhas, com sacadas de madeira e treliças nas janelas. Tal aspecto é ressaltado no relato que segue:

Muitas das casas em São Sebastião estão longe de serem contemptíveis, têm no máximo dois andares, são cobertas com telhas e têm sacadas de madeira que se estendem na frente do andar superior; mas as melhores têm aquela aparência desluzida e melancólica que todas as construções, cujas janelas de treliça suprimem a carência de vidro, precisam necessariamente ter. (BARRINGTON, George in. BRITO, 2006, p.44)

As ruas eram atravancadas e sujas, sempre com uma grande circulação de pessoas, na sua maioria escravizados. As condições de vida caóticas e insalubres faziam com que os habitantes da cidade fossem constantemente vítimas de doenças e epidemias. A situação começa a mudar com a transferência da Corte para o Rio de Janeiro, fazendo com que mudanças fossem realizadas para melhorar a saúde, higiene e saneamento a fim de erradicar as doenças. Assim que chegou a cidade,

\begin{abstract}
(...) o príncipe regente encomendou ao físico-mor do reino, Manoel Vieira da Silva, uma memória na qual avaliasse as condições de salubridade da nova Corte e sugerisse soluções para os problemas existentes. Em seu relato, Vieira da Silva avalia que, embora os morros realmente perturbassem a circulação do ar, o maior problema da cidade eram os pântanos e charcos, que deixavam 0 ar sempre úmido, o que, associados ao intenso calor, conformavam ambiente propício para o desenvolvimento dos 'miasmas e febres perigosas' que resultavam nas epidemias que frequentemente assolavam a população. (HONORATO, 2006, p.38)
\end{abstract}

As propostas apresentadas para sanar os problemas levantados pelo relatório do físico-mor do reino eram basicamente aterrar os pântanos, alargar as ruas e impedir a construção de casas baixas em 
todas as áreas da cidade, como forma de melhorar a ventilação dentro da cidade. A partir dessas diretrizes começam as já citadas intervenções para garantir a melhoria da qualidade de vida e o desenvolvimento da metrópole tropical.

Foram longos os anos em que esse aperto caracterizou o espaço construído da cidade em sua área urbana, pelo menos até o início das obras que melhoraram a mobilidade entre algumas freguesias rurais e as do Centro. Além de tantas peculiaridades em sua paisagem, o Rio de Janeiro também possuía outro fator que chamava a atenção: quase metade dos habitantes eram pessoas escravizadas. Sobre este aspecto é importante ressaltar que,

(...) na área urbana, ela [população escravizada] chegou representar $46 \%$ do total da população em 1821, enquanto a população livre representava $54 \%$ desse total, se somarmos a ela a população da área rural, onde os escravos representavam a maioria, e sabendo-se que a população total entre 1799 e 1821 atingiu a cifra de 112.695, observamos que o percentual de escravos sobe para $49 \%$ enquanto o de livre cai para $51 \%$, o que demonstra que mesmo sendo a população livre maior que a população escrava essa diferença percentual era muito pequena.

(HONORATO, 2008, p.45)

Eram poucos os residentes livres e a elite dirigente/militar/mercantil que comandava política e economicamente a cidade era ainda mais reduzida. Desse modo, os traços de diferenciação que organizavam o mundo colonial começavam a aparecer. Fosse na aparência das casas, ou pelos costumes, roupas e hábitos, era de extrema importância que a elite realizasse as cisões necessárias para manter a compartimentação estruturante que distanciavam o mundo da soberania e o dos subalternos. (Abreu, 1985, p.27)

Esse processo de diferenciação social começa a ser visível a partir da especialização de algumas áreas da cidade que, ligadas as atividades comerciais que haviam se ampliado a partir da descoberta do ouro, começam a demonstrar funções mais delimitadas dentro da ocupação urbana. Deste modo,

(...) podemos constatar que a mineração contribuiu para a expansão física e demográfica da cidade. Até aproximadamente 1730 , a malha urbana se limitava ao morro do Castelo e adjacências, não indo muito além da Prainha (atual rua do Acre), rua da Vala (atual rua Uruguaiana) [...] e 
rua da Ajuda; durante aquele século outras áreas foram adquirindo uma característica urbana, entre elas destacamos Glória, Lapa, o Largo das Pitangueiras (largo do Machado). Ao mesmo tempo núcleos de povoamentos foram sendo formados em direção à Mata-Cavalos (Riachuelo) e além da Prainha, [...], em área mais tarde ocupada pelos bairros da Saúde e Gamboa. Quanto à população em 1713 era de 12.000, passou para cerca de 30.000 em 1760.

(HONORATO, 2008, p.32)

\section{Ainda sobre esse fenômeno verifica-se que}

O bairro da Misericórdia, trecho da planície mais próximo ao morro do Castelo, concentrava o grande comércio, nesta área residiam os mais importantes contratadores dos produtos territoriais; encontrava-se também a Santa Casa da Misericórdia, fundada em 1582, a Alfândega, o Senado da Câmara, e na praia de D. Manoel o cais de desembarque das mercadorias e carregamento dos gêneros de exportação, depósitos dos principais trapiches. Mas o crescente movimento comercial requeria mais espaço. Assim, durante o governo de Gomes Freire de Andrade (1735-1762) iniciaram-se as obras de aterro, ampliando as atividades portuárias que foram se estendendo da praia de D. Manoel para a praia do Mercado com a construção de estaleiros, barracas e trapiches. (HONORATO, 2008, p.32)

As transformações no espaço urbano que permitiram tais alterações também começam a deixar traços na organização social das cinco freguesias urbanas. Em 1821 as freguesias da Candelária e São José passam a ser o local preferencial para a residência das classes dirigentes, visto a presença do Paço Real, na atual Praça $X^{3}$, e as unidades administrativas do Reino. As ruas recém-abertas do Pantanal de Pedro Dias (ruas dos Inválidos, do Lavradio e do Resende, no atual bairro da Lapa) concentravam um grande número de sobrados dos membros do poder público da cidade, além das residências já existentes na freguesia da Candelária. (Abreu, 1985, p.29). Já a população menos abastada, com um reduzido poder de mobilidade, concentravam-se nas outras

\footnotetext{
3 "Um dos espaços mais emblemáticos do Centro é a Praça $X V$, que foi construída junto à praia que a servia de porto desde o século $\mathrm{XVI}$, e estava protegida pelas baterias da Ponta do Calabouço, situadas no Morro do Castelo. Durante o século XVIII se implantou nela um cais portuário, que limitou a nova praça conformada ao estilo do Terreiro do Paço de Lisboa como mostra do poderio da cidade, associado ao ciclo do ouro. Para a construção desse dique, a cidade avançou sobre o mar, iniciando-se assim outra prática que também se tornou uma marca constante na extensão da cidade nos séculos seguintes. A praça foi remodelada, devido à construção do Palácio dos Governadores em 1743, e o dique acabado em 1789." (ANDREATTA, 2006, p.28)
} 
freguesias, especialmente nas de Santa Rita e Santana, resultando no aparecimento dos atuais bairros da Saúde, Santo Cristo e Gamboa.

Esse processo de diferenciação social também se manifestou nas freguesias rurais. As regiões que se encontravam distantes do centro permaneceram exclusivamente rurais, atuando principalmente no fornecimento de gêneros alimentícios para a Corte enquanto as mais próximas da área urbana tiveram as suas fazendas desmembradas em chácaras. Essas inicialmente destinadas às atividades de fim-de-semana, tornaram-se locais permanentes de moradia das elites fazendo com que novas freguesias fossem criadas. Estas,

[as freguesias exclusivamente rurais] pouco cresceram também
em população. Muitas delas, entretanto, apresentavam intensa
atividade econômica, como atestam a instalação de olarias e
curtumes na freguesia de Inhaúma, e o crescimento dos
pequenos portos de transbordo de mercadorias destinadas à
área urbana (Inhaúma, Maria Angu, Brás de Pina, Pavuna). O
mesmo acontecia, e em maior escala, nos portos da Baixada
Fluminense, notadamente Piedade de Magé, Inhomirim,
Estrela, Iguaçu, Mauá e Porto das Caixas, que tiveram nessa
época a sua fase áurea de desenvolvimento como entrepostos
comerciais. (ABREU, 1985, p.35)

Desse movimento surgiram grandes residências no atual bairro de Laranjeiras e o adensamento populacional do Catete e da Glória, ocasionando a criação da freguesia da Glória em 1834, desmembrada da de São José. Conforme aponta Andreatta

\footnotetext{
“(...) já em 1740 quando foi construída a Igreja de Nossa Senhora da Glória, que nomeou seguidamente o outeiro em que localizou-se, aumentou o prestígio pela região, incentivando o início das edificações no seu entorno." (ANDREATTA, 2006, p. 37)
}

Nesse mesmo período uma profusão de outras chácaras aparece também em Botafogo, até então um arrabalde da freguesia da Lagoa, localizadas principalmente próximas à praia de Botafogo na rua de São Clemente e na de São Joaquim da Lagoa (atual Voluntários da Pátria). Além disso,

(...) a mudança da princesa Carlota Joaquina com suas filhas para uma chácara em Botafogo também incentivou a mudança de membros da aristocracia carioca para a região. Ainda restam algumas construções desse período como Palácio do Marquês de Leão, o do Comendador dos Santos (atual Faculdade de Medicina) e o do Barão de Friburgo (Palácio do Catete), entre outros. 
(HONORATO, 2008, p.35)

Outra região rural que também se tornou um destino das elites no século XIX foi o velho arraial, de São Cristóvão. Graças à presença da residência Real e do aterro da parte do Saco de São Diogo vizinha ao Caminho do Aterrado, ou das Lanternas (atual lado par da Av. Presidente Vargas), que fazia conexão com a Quinta da Boa Vista, a freguesia passou a ser procurada pelos que tinham maior poder de mobilidade.

Assim que a Câmara Municipal concluiu todo o serviço de aterramento, resolvendo o problema de acessibilidade, o bairro recebeu um número ainda maior de moradias ricas que, de forma mais moderada, alcançaram até a ponta do Caju. A área alcançou grande prestígio, sendo inclusive contemplada, em 1838, com uma das linhas do primeiro transporte público de tração animal da cidade, chamado de 'gôndolas' (Andreatta, 2006, p.30).

Com o grande movimento das elites se distanciando do centro, em busca de uma melhor qualidade de vida em espaços mais segregados, as freguesias do centro da cidade passaram a abrigar cada vez mais as populações com menor poder aquisitivo. Com capacidade de mobilidade quase nulo, seus moradores eram praticamente os que necessitavam da localização central, ou próxima ao centro, para sobreviver. $O$ fato de concentrar uma grande oferta diária de possibilidade de trabalho atraía muitas pessoas livres e escravizadas, principalmente para a região portuária que se configurava em torno do Paço Real, tornando-se uma das áreas de maior efervescência da cidade colonial.

Outro local emblemático da região central era o Campo de Santana (atual Praça da República). Um campo aberto, que por muito tempo foi usado como área de reunião do gado para o Matadouro e também por tratantes e escravizados. Seu nome foi dado devido a construção em 1735 da capela de Santa Ana. Sobre a consolidação espacial do Campo de Santana é importante apontar que sua forma era fruto do recorte feito pelas chácaras estabelecidas no entorno, como consolidação das sesmarias, sendo por muito tempo o local de despejo dos resíduos locais e do lixo da cidade. 
Na virada para o século XIX, o Vice-Rei em exercício, Conde de Resende, ordenou a regularização do campo, aterrando suas bordas alagadas e fixando o alinhamento das edificações dando início ao seu formato de praça. No Campo de Santana também estava localizado o chafariz mais importante da cidade, construído de forma provisória em 1811 e de maneira definitiva em 1818 (Andreatta, 2006, p.31).

Ainda dentro do perímetro urbano estava localizada a freguesia de Santa Rita, que passa a ter maior importância para a cidade do Rio de Janeiro a partir da transferência do mercado de escravizados, que situava-se na Praça XV, para a região chamada de Valongo em 1774. A freguesia de Santa Rita compreendia uma faixa estreita de terra comprimida entre as águas da Baía de Guanabara e uma densa formação montanhosa que praticamente mantinha a área isolada do restante da cidade.

Em 1721 foi erguida na região a Igreja de Santa Rita, localizada aos pés do Morro da Conceição onde hoje encontra-se o final da avenida Marechal Floriano (antiga rua de São Joaquim), esquina com a rua Visconde de Inhaúma. A região passou por um forte período de expansão, após a instalação do mercado do Valongo, que somado ao seu potencial para as atividades pesqueiras e de embarcadouros, concentrava um grande número de trapiches em seu litoral que estendia-se da Prainha até o Saco dos Alferes e a Praia Formosa. A região também passou a atrair um grande número de moradores devido ao fato de estar localizada perto da cidade e possuir uma profusão de amplos terrenos para a exploração agrícola de subsistência que transformaram-se em chácaras implantadas em terras distribuídas através de cartas de sesmaria (Honorato, 2008, p.31).

Através desse panorama sobre a organização social do Rio de Janeiro, principalmente dos anos entre 1750 a 1870, é possível realizar um diagrama demonstrando a forma segregacionista adotada pela cidade a partir desse período. Fica clara a concentração da elite administradora/militar/mercantil nas regiões rurais afastadas do centro. Esse movimento é resultado da busca por lugares mais salubres e afastados das freguesias urbanas que tornavam-se cada vez mais 'sujas' 
e movimentadas, visto a intensa presença de um mercado de rua ativo e pela marcante circulação de escravizados. Restaram nessa área também parte dos chefes dirigentes e habitantes com maior poder aquisitivo, mas que necessariamente não faziam parte da elite, que em sua maioria estavam ligados ao comércio e às atividades portuárias.

A freguesia de Santana estava repleta de pântanos e, consequentemente, de usos considerados pouco adequados para a permanência das elites, o que acarretou em uma maior concentração de pessoas com baixa renda. Da mesma forma a freguesia de Santa Rita, mesmo adquirindo maior importância para a dinâmica da cidade após a transferência do mercado de escravizados para o Valongo, estava isolada por obstáculos naturais o que era considerado interessante, visto o desejo de grande parte da população carioca de afastar o máximo possível o comércio de escravizados das suas vistas. É sabido que as divisões sociais e estratificações não eram circunscritas de forma tão clara, porém, a concentração de determinadas classes e grupos em lugares específicos auxilia na compreensão de como se deu a compartimentação do espaço

Quadro 3. Diagrama de Organização social do Rio de Janeiro colonial (1750-1870)

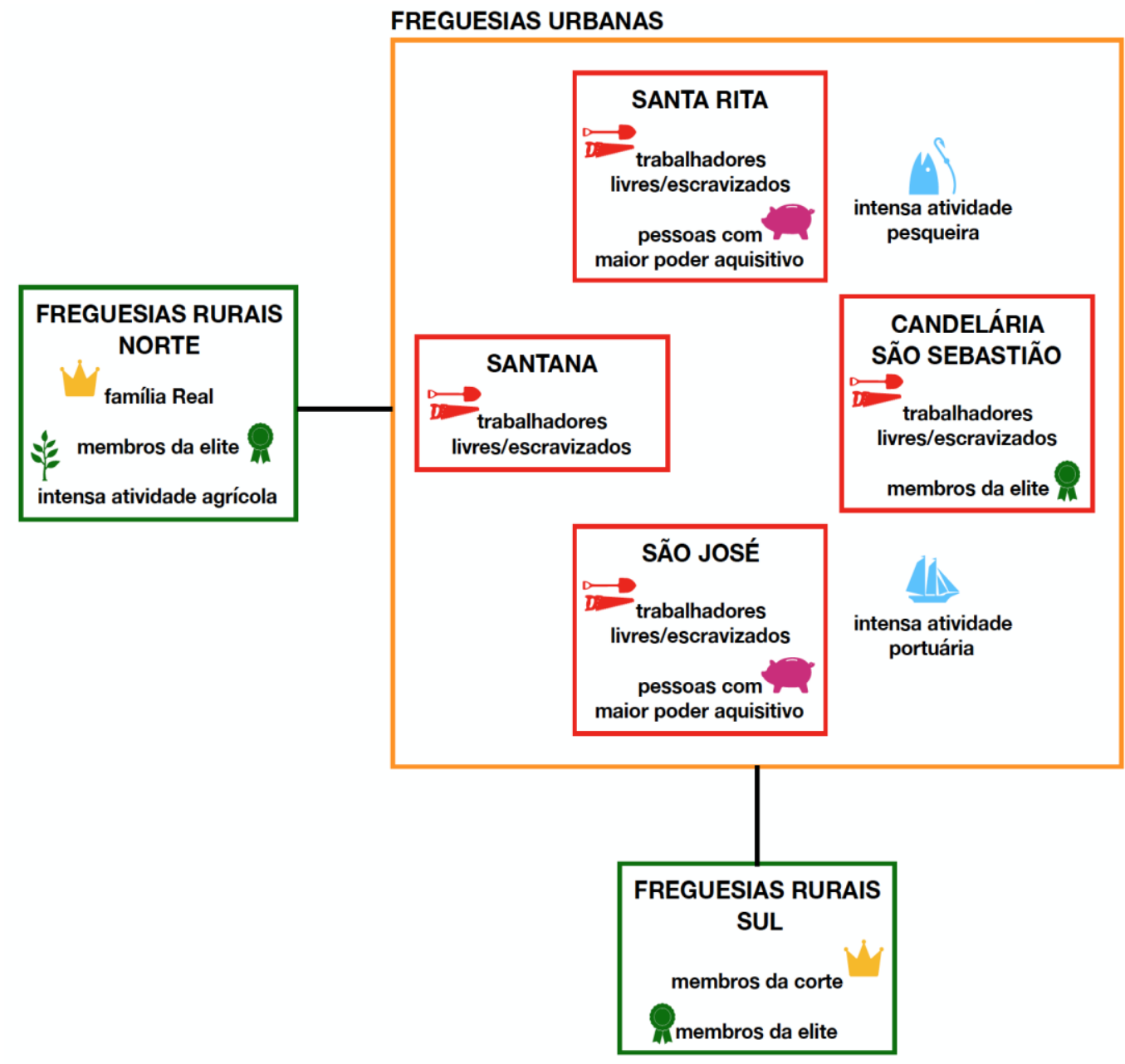

Fonte: Do autor. 
Ao olharmos mais atentamente para o processo de estruturação urbana da cidade do Rio de Janeiro é possível perceber como vários fatores influenciaram a dinâmica da cidade, bem como o seu desenvolvimento ao longo do tempo e do espaço. A adaptação às condicionantes naturais através da ação direta na paisagem como, por exemplo, no desmanche de morros e aterramentos de grandes áreas alagadas, foi um dos grandes impulsionadores nesse processo. Porém, ainda mais contundente estão as transformações sociais, políticas e econômicas, que ditavam quais as decisões seriam tomadas em uma esfera administrativa e garantiu grande parte da estrutura segregacionista que marca as ocupações coloniais.

Estes fenômenos toram imprescindíveis uma abordagem mais abrangente nos estudos sobre a estruturação urbana, sendo

(...) necessário que se examine, a cada momento, a interação que se estabelece entre os processos econômicos, sociais e políticos que se desenvolvem na cidade, e a forma pela qual o espaço se estrutura. Espaço e sociedade precisam ser analisados conjuntamente para que a complementaridade entre processo e forma fique evidente. Isso implica, de um lado, estudar como, numa sociedade historicamente determinada, 0 espaço urbano é elaborado, ou seja, como os processos que têm lugar nas cidades determinam uma forma espacial. Por outro lado, implica também estudar a essência das formas, ou seja, o papel por elas desempenhado nos diversos momentos por que passa a sociedade no tempo.

(ABREU, 1985, p.10)

Por essa razão é importante também levar em consideração o papel do Estado como um dos responsáveis pela organização que se desenvolveu tão próxima dos interesses de uns em detrimento de muitos. Deste modo,

(...) partimos da premissa que, se a estrutura atual da área metropolitana do Rio de Janeiro se caracteriza pela tendência a um modelo dicotômico do tipo núcleo-periferia, onde a cidade dos ricos se contrapõe àquela dos pobres, isto não se deve apenas às forças de mercado. Tal estrutura, também seria função do papel desempenhado pelo Estado no decorrer do tempo, seja através da criação de condições materiais que favoreceram o aparecimento desse modelo dicotômico, seja mediante 0 estabelecimento de políticas que, embora objetivando muitas vezes regular conflitos entre o capital e o trabalho, sempre acabaram sendo benéficas àquele e em detrimento deste.

(ABREU, 1985, p.7) 
Isso nos mostra que, longe de ser o agente neutro que atua em benefício da sociedade de modo geral, como pregado pelo pensamento liberal, o poder público aliou-se, através do tempo, a diversas unidades do capital. Tal decisão legitimou e expressou interesses que sedimentaram o modelo segregador do espaço na cidade do Rio de Janeiro. A forma como algumas políticas públicas foram estabelecidas deixam claras essas intenções,

Isso quer dizer que os padrões de distribuição espacial das classes sociais no Rio teriam sido altamente influenciados pelo Estado através do tempo, tanto por suas ações como por suas omissões. Essas políticas (ou não-políticas) seriam, por sua vez, bastante representativas dos momentos de organização social em que foram formuladas.

(ABREU, 1985, p.7)

Sendo o capital, com apoio e legitimação do Estado, um dos maiores responsáveis por promover a segregação espacial na estruturação da cidade do Rio de Janeiro, é preciso considerar o elemento que se mostrava como a espinha dorsal da economia carioca no período colonial: a escravização. Tanto pelo comércio de cativos ou nos meios de produção de base escravista é determinante considerar o sistema de comércio e exploração de trabalho de negros-africanos escravizados como uma das lógicas que moviam a cidade, fazendo refletir seus conflitos e interesses no espaço urbano de forma visível (Abreu, 1985, p.28). Para que se tenha uma noção da expressividade do comércio escravista na cidade vale afirmar que,

\begin{abstract}
A partir do século XVIII, o Rio de Janeiro tornou-se o maior importador de mão de obra africana das Américas e grande centro distribuidor de todo o Brasil. Sabendo-se que entre 1790 e 1830 pelo porto carioca tenha entrado para o Brasil 17.023 africanos. Pode-se concluir que o volume de importações brasileiras através do porto carioca tenha sido o maior do mundo, pois era superior aos 14.500 escravos que anualmente cruzavam o Sahara para os países árabes, segundo maior fluxo de cativos do mundo no século XIX. Portanto, do ponto de vista econômico a sua posição era ímpar no contexto colonial especialmente a partir de 1760 .

(HONORATO, 2008, p.62)
\end{abstract}

O papel do Rio de Janeiro, primeiro como grande praça mercantil, depois sendo capital do país e seguidamente a sede da Corte Real portuguesa, também foram fatores determinantes para a grande concentração de negro-africanos escravizados em solo carioca. Em 1752, 
instala-se na cidade o Tribunal da Relação, transformando o Rio de Janeiro no novo polo jurídico do Brasil, trazendo à cidade um grande número de funcionários públicos, pertencentes à elite, que precisaram acomodar-se e demandaram uma quantidade significativa de serviçais e moradias.

Alguns anos depois, em 1763, o Rio de Janeiro é nomeado como a capital da colônia, sede do vice-reinado, fazendo com que houvesse um incremento do porto, o tornando o mais importante (deixando para trás áreas tradicionais como Bahia e Pernambuco), alçando a cidade ao posto de maior centro comercial do Brasil. O crescimento da população entre o período de 1760 e 1780 é de 29\%, já entre 1799 e 1821 esse índice dispara, alcançando o percentual de $160 \%$. Esse aumento indica um crescimento que faz o número de habitantes pular de 169 mil habitantes em 1789 para 591 mil em 1830, um crescimento de 250\%. Esses números apontam que os momentos de movimentação política e social aumentaram a necessidade de mão de obra escravizada, visto que dos 591 mil habitantes, $57 \%$ eram negros-africanos cativos (Honorato, 2008, p.63).

O que foi tentado demonstrar até o momento é a correspondência entre o padrão de mundo compartimentado, característico das ocupações coloniais, e o processo de estruturação urbana do Rio de Janeiro no seu período colonial. Como visto, a meta da organização implantada nesses espaços era deixar claramente expostas as diferenças sociais entre soberania e negros-africanos escravizados. Essa postura era necessária para que a condição de 'morte social', que garantia a existência do cativo como uma 'sombra petrificada', fosse alcançada. A redução do escravizado ao status de 'morto-vivo' (Mbembe, 2016, p.132), caracterizava a sua sujeição e com isso a efetivação da dominação necessária para que as intenções da soberania fossem alcançadas.

Tendo em vista o levantamento realizado sobre a cidade do Rio de Janeiro, fica evidente como a presença numerosa de cativos na colônia provocou mudanças que podem ser sentidas até os dias de hoje. O que é visto nessa progressão espaço-temporal do modelo segregacionista de ocupação é que os elementos que atenuaram a compartimentação social 
foram esboçados no século XVIII e lançados no espaço durante o século XIX, acelerando a dispersão dos usos e classes sociais que se encontravam amontoados na antiga cidade colonial.

A introdução de novos meios de transporte, como o bonde de burro e o trem a vapor, a partir de 1870, constituem-se como impulsionadores do crescimento físico da cidade que leva as classes 'nobres' para os bairros servidos por bondes, principalmente os localizados na zona sul (Abreu, 1985, p.29). É também a partir desse período que o sistema escravista começa a entrar em colapso, fazendo com que os seus programas já não encontrem mais suporte para o funcionamento, tornando obsoletos e disfuncionais diversos aparelhos e dispositivos de controle.

\subsection{O outro lado do espelho}

Enquanto estava ocupado, dominando o mundo em sua empreitada colonial, um branco-europeu que se olhava no espelho buscava em resposta ver-se refletido nele. Toda a sua construção identitária estava baseada em um exercício de autoficção, autocontemplação e, acima de tudo, enclausuramento (Mbembe, 2014, p.10).

Como resposta a essa postura ensimesmada o negro-africano permanecia trancafiado do outro lado do espelho, sendo o inverso do mundo ordenado e luminoso criado acima do seu poder de alcance. Não só como um ser incompleto na sua humanidade, o negro-africano escravizado era também transformado em inimigo, em um intruso, que ameaçava o branco-europeu soberano, tornando-o a vítima. Sobre esse processo é importante perceber que,

Este fato é baseado em processos nos quais partes cindidas da psique são projetadas para fora, criando o chamado 'Outro', sempre como antagonista do 'eu'. Essa cisão evoca o fato de que o sujeito branco de alguma forma está dividido dentro de si próprio, pois desenvolve duas atitudes em relação à realidade externa: somente uma parte do ego - a parte "boa", acolhedora e benevolente - é vista e vivenciada como 'self', como 'eu' e o resto - a parte "má", rejeitada e malévola - é projetada sobre o 'Outro' e retratada como algo externo. O 'Outro' torna-se então a representação mental do que o sujeito branco teme reconhecer sobre si mesmo, neste caso: o ladrão/a ladra 
violento(a), o(a) bandido(a) indolente e malicioso(a). (KILOMBA, 2010, p.174)

Na lógica do mundo colonial não bastava ao soberano explorar até as últimas forças o trabalho do escravizado, era necessário também transformá-lo na própria essência da maldade, ou da imbecilidade completa, sobrando ao seu senhor domesticá-lo como um animal ou tratálo como uma criança incapaz de tomar decisões e fazer escolhas. Alguns acreditaram ser possível o estabelecimento de algum afeto no interior destas relações, e até mesmo criou-se o imaginário de um 'senhor benevolente', que teria operado uma escravização de forma mais branda nas terras brasileiras. Esse mito, ao lado da utopia de uma 'democracia racial' andam de mãos dadas em inúmeros pensamentos sobre o racismo e a escravização negro-africana no Brasil, e também sobre a refutação de ambas as teses muitas páginas já foram escritas. Em especial é possível citar a obra de Abdias do Nascimento (2017), O genocídio do negro brasileiro, como um pensador negro que lutou incansavelmente contra os mitos e ficções que tentam escamotear as verdadeiras intenções do sistema escravista no Brasil.

O que cabe à reflexão que seguirá nas próximas páginas é observar que mesmo com a ausência de violências físicas ao corpo do escravizado, a soberania colonial mantinha o cativo aprisionado em um labirinto de imaginários e estruturas físico-espaciais, que impossibilitavam existências outras que não a do 'morto-vivo', condenado a permanecer acorrentado ao fantasma de si mesmo. Em busca da visualização do que poderia ser esse ambiente segregador, iremos percorrer alguns dos limites e fronteiras que constituíam, o outro lado do espelho. A 'outra' parte do mundo compartimentado no qual se constituiu o Rio de Janeiro colonial: a cidade do escravizado.

Antes de prosseguirmos, faz-se necessário dois apontamentos importantes. O primeiro deles diz respeito às barreiras que dividiam os mundos da soberania e do escravizado. Muitos desses limites se materializavam no espaço, como elementos físicos que dificultavam a passagem ou até mesmo a impossibilitavam. Por outro lado, algumas dessas interdições estavam ligadas a construções sociais, arranjos esses 
mais difíceis de serem identificados e mantidos em segurança pela soberania com base na violência e no regime de medo. Esse ponto talvez já estivesse claro, porém cabe aqui a citação de Mary Karasch acerca dessa questão:

\begin{abstract}
"Para eles [escravizados] era uma cidade de fronteiras, de limitações, de limitações à liberdade. Alguns desses limites podiam ser cruzados com relativa facilidade e uns poucos, através de portões estreitos, mas outros eram muros intransponíveis. O problema para cada escravo era determinar quais as fronteiras podiam ser cruzadas. As fortificações, muros e mansões com cercas de ferro eram barreiras óbvias; menos claro eram as construções sociais que não ousavam trespassar com medo de maus-tratos brutais. Como os novos escravos iriam aprender mediante experiências amargas, poucos conseguiam romper as barreiras sociais, políticas e econômicas que protegiam a posição privilegiada das famílias de elite e seus escravos de status elevado, e isso os relegava ao fim da linha.
\end{abstract}

(KARASCH, 2000, p.99)

O segundo ponto diz respeito a figura do negro-africano. Sobre este podemos dizer que,

\footnotetext{
É caçador de clandestinos e de fugitivos, capataz e ajudante de capataz, escravo artesão, intendente, doméstico, cozinheiro, liberto mantendo-se submisso e, ocasionalmente, guerreiro. Estes estatutos estão longe de ser estáveis. De acordo com as circunstâncias, uma determinada posição pode subitamente sofrer uma 'reviravolta'. A vítima de hoje poderá, amanhã, transformar-se em carrasco ao serviço do seu senhor. Não é estranhar que o liberto de hoje se torna um proprietário e caçador de escravos amanhã.

(MBEMBE, 2014, p.40)
}

Esse caráter dinâmico e imprevisível da figura do negro-africano na colônia deixa clara a situação de intensa instabilidade com a qual os cativos, mesmo depois de libertos, precisavam enfrentar o mundo que 0 circundava. As diversas posições que ocupavam dentro da sociedade mostram que a relação de servidão era estabelecida além das formas fragmentadas de sujeição, da insegurança, dos conflitos gerados pelo ciúme, 'do jogo movediço das alianças, as táticas ambivalentes feitas de cumplicidades, esquemas de toda a espécie e feitio, as condutas de diferenciação num pano de fundo de posições reversíveis' (Mbembe, 2014, p.41). A submissão do escravizado era caracterizada também pelo fato de o vínculo social da exploração não se apresentar logo de uma vez. Ele era construído, produzido e reproduzido, constantemente por meio da 
violência. Por isso, muitos são os casos de insurreições e revoltas por parte dos escravizados, aos quais a soberania

\begin{abstract}
(...) poderá até dominar, criar cadeiras de dependência entre si e seus escravos, alternar horror e evergetismo, mas a sua vida será permanentemente assombrada pelo anátema do extermínio. O escravo negro, pelo contrário, encontra-se constantemente no limiar da revolta, tentando responder ao apelo lancinante da liberdade ou da vingança, ou então, num gesto de aviltamento máximo e de abdicação radical do sujeito, procurar proteger a sua vida, deixando-se utilizar no projeto de servidão de si e de outros escravos.
\end{abstract}

(MBEMBE, 2014, p.41)

Grosso modo, mesmo que o escravizado alcançasse algum tipo de elevação na estrutura social que ocupava não deixaria de ser um negroafricano, ou melhor dizendo, jamais se tornaria o branco-europeu. Por sua vez, mesmo que o homem branco-europeu fosse um trabalhador pobre e que não compartilhasse dos privilégios da elite, jamais seria um escravizado. Por isso se faz importante o reforço do primeiro ponto, a segregação do mundo colonial dava-se pela violência ao corpo juntamente com a violação do status de sujeito político/econômico/jurídico do negro-africano.

Lançados esses primeiros apontamentos, que servem como nossos fios de Ariadne dento do labirinto que iremos explorar, seguiremos nosso percurso. Iniciaremos pelos limites físicos, que estavam distribuídos em grande quantidade nas freguesias urbanas do Rio de Janeiro. Frantz Fanon (1965, p.27), ao descrever o mundo colonizado, aponta as unidades policiais e militares como os sinalizadores das linhas de separação espacial do mundo colonial compartimentado. "O mundo do colonizado é um mundo dividido em dois. A linha divisória, a fronteira, está indicada pelos quartéis e pelos postos de polícia".

Seguindo esse padrão, era notável no espaço urbano carioca esta mesma característica. Nas ilhas próximas da Baía de Guanabara estavam instalados fortes, bem como na entrada do porto e na llha das Cobras, onde também se localizava uma prisão de escravizados considerados criminosos. Na região central estava o arsenal militar, onde na praça do Paço Imperial havia sido anteriormente o Calabouço, antiga prisão de escravizados. No topo dos morros do Castelo e da Conceição havia 
outros fortes que protegiam a cidade que, somados aos navios de guerra armados que ancoravam no largo, compunham um cenário de constante vigilância. Além desses elementos em destaque na paisagem, no interior de cada freguesia estavam localizados quartéis e delegacias policiais. Todos esses elementos, que traziam a tranquilidade necessárias para a soberania tornava mais difícil a revolta e a fuga dos escravizados por terra e por mar (Karasch, 2000, p.100).

Em todas as regiões da cidade, além de unidades de controle policial e militar, as igrejas também estavam presentes, fazendo-se notar desde o auto dos morros até em locais planos, produzindo também o controle 'sagrado' do espaço urbano. A representação física da 'soberania religiosa' dos senhores espalhava-se ainda na forma de estátuas e santuários religiosos que ficavam na cabeceira das ruas e entrada das casas.

Sendo a fé católica a única religião admitida pelos senhores, muitos escravizados manifestavam sua crença em igrejas próprias, que deveriam ser construídas em locais afastados dos centros políticos, comerciais e religiosos da cidade. Seguindo essa condição, entre as igrejas mais estimadas pelos escravizados estavam, (...) a de Nossa Senhora do Rosário e São Benedito e de
Nossa Senhora da Lampadosa, que ficavam perto da atual
praça Tiradentes. Entre essa praça e o morro da Conceição
estavam Santa Ifigênia e Santo Elesbão, São Domingos e a
capela de Nossa Senhora da Conceição do Cônego enquanto
São Gonçalo Garcia, Santa Ana e a capela dos Pretos ficavam
no campo de Santana ou em suas proximidades.

(KARASCH, 2000, p.101)

Os espaços públicos, que geralmente acompanhavam essas edificações religiosas também eram de extrema importância no universo ocupado pelo escravizado. Esses locais, vistos como ambientes desregrados e sujos, eram o destino de muitos cativos que escapavam dos seus senhores nas tardes de domingo para dançar ao som de sua música, como acontecia no Campo de Santana.

Se o girar das saias e os batuques ajudavam a amenizar a realidade do cativeiro, a presença da morte e da violência não permitia que fossem esquecidas totalmente as dificuldades da vida que levavam. 
Nesses momentos de socialização e lazer, o terror se fazia presente na forma dos pelourinhos, símbolos das punições públicas que eram executadas nesses mesmos espaços onde podiam usufruir da sua restrita liberdade.

Além do campo de Santana, outras praças possuíam esse caráter duplo, de pelourinho e local de encontro. A mais importante era a praça Tiradentes perto da igreja de Nossa Senhora da Lampadosa, onde negros-africanos encontravam-se diariamente, bem como realizavam procissões religiosas, funerais e celebrações em homenagem aos reais líderes do seu povo (Karasch, 2000, p.102).

Mesmo vivendo nesse espaço repleto de restrições, os escravizados possuíam o controle de algumas áreas da cidade. Esse domínio espacial estava geralmente associado à presença de um forte comércio de rua onde se vendiam artigos de armarinho e alimentos. Enquanto os senhores dormiam nas horas de calor mais intenso do dia, os cativos reuniam-se nas ruas, era esta intensa circulação que fazia os estrangeiros se sentissem plena África ao chegar no Brasil.

Um desses espaços notáveis era justamente a região portuária e as proximidades da Alfândega, na rua Direita (atual Primeiro de Março), onde os escravizados trabalhavam ativamente como carregadores $\mathrm{e}$ estivadores, ajudando a descarregar passageiros e cargas dos navios. A presença dos trabalhadores negro-africanos no porto trazia consigo o aroma das comidas típicas que eram preparadas pelas mulheres que vendiam seus pratos quentes na região aos escravizados que não eram alimentados pelos seus senhores, sendo as quitandas do Largo do Rosário e na praia de Dom Manoel as mais populares.

Era também na região portuária que escravizados vindos das áreas rurais, para comprar e vender produtos para as fazendas, misturavam-se aos cativos das freguesias urbanas, possibilitando uma interação um pouco mais livre da presença restritiva de seus senhores (Karasch, 2000, p.103). Cabe lembrar que essa intensa atividade nas ruas não era vista com bons olhos pelas autoridades, e sociedade civil de forma geral. Parte do processo 'civilizador' estava engajado em controlar essa movimentação, para evitar as revoltas e amenizar o 'medo' das elites, que 
(...) andavam receosos pelos becos e vielas em geral estreitos e irregulares, sujos, malcheirosos e sombrios onde se amontoavam um grande número de escravos, mendigos e desocupados, excluídos da sociedade, destituídos de quaisquer direito, mas sempre prontos a mostrar sua presença e suscitar o imaginário de uma elite que já na época temia a africanização do Brasil. Os escravos africanos começam a ser temidos não apenas como indivíduos, mas também como sujeito coletivo, o que agravava o medo de que ocorresse no Brasil episódio semelhante ao do Haiti, em 1794 e nos anos seguintes. (HONORATO, 2008, p.47)

Outro elemento agregador na estrutura do mundo dos escravizados era a água. Fosse na forma das fontes e poços, ou nas praias e nos lagos, os cativos estavam diretamente ligados a esses pontos da cidade. O sistema de água do Rio de Janeiro utilizava aquedutos e fontes públicas na praia dos Mineiros, no largo da Carioca, no Passeio Público e no Paço. Sendo assim,

Uma vez que a maioria das casas, esmo as dos ricos,
dependia da água dessas fontes, uma das visões mais comuns
do Rio era a de escravos esperando na fila da água ou
carregando jarras e barris cheios na cabeça. Mas essas
cansativas viagens em busca de água davam-lhes muitas
oportunidades para interagir com outros escravos - nem que
fosse apenas ao disputar um lugar na fila. (KARASCH, 2000,
p.103)

As águas doces dos rios e lagos eram o fardo que precisava ser carregado pelos escravizados que trabalhavam no subúrbio e abasteciam os seus senhores, e também era o material de trabalho de lavadeiras que batiam e esfregavam as roupas em pedras, torciam-nas e as espalhavam no capim para secar. Eram as águas também que poderiam significar momentos de lazer, quando era possível o banho de mar, ou o contato com suas próprias crenças religiosas, nos rituais para as divindades das águas fortemente presentes nas religiões de matriz africana.

Para alguns, a água poderia representar a liberdade, mesmo que temporária, quando estavam trabalhando nos barcos e jangadas para além dos fortes. Algumas dessas viagens eram feitas sozinho, mas na sua grande maioria contavam com a presença dos senhores ou de outros 
escravizados, geralmente ao longo da costa ou atravessando a baía até Praia Grande (Niterói) ${ }^{4}$.

Fosse fardo ou benção, a água era parte inseparável da vida dos escravizados na cidade, habitada por divindades e perigos que eram descobertos a cada contato. Se o espaço construído e natural já lançava no espaço diversos signos e elementos complexos de ultrapassar e decifrar, ainda mais difícil era conviver com os arranjos sociais, que eregiam 'barreiras etéreas' no espaço, na forma de estratificação social.

O sistema escravista passou por cima de diversos acordos e estruturas sociais pré-existentes de grupos étnicos inteiros e impôs um novo ordenamento onde, por exemplo, representantes de linhagens ancestrais eram tornados subalternos, igualados aos seus súditos e até rebaixados pelo colonizador que os tornava objeto de exploração. Porém, essas figuras de liderança não deixavam de ser homenageadas e respeitadas pelos seus companheiros de cativeiro, que continuavam prestando honrarias aos seus legítimos chefes e herdeiros que estavam em seu convívio na cidade.

Se os seus líderes não tivessem vindo da África, [os
escravizados] escolhiam seus próprios governantes nacionais e
coroavam reis e rainhas, transferindo para eles o status devido
a líderes africanos legítimos. O viajante Dabadie conheceu um
velho esfarrapado, antigo negro de ganho, que fora rei na
África. Sempre que sua gente o via, saudava-o e pedia sua
bênção. Além disso, os escravos pagavam tributo a seus
soberanos, o que assumiam amiúde a forma de contribuições
para a compra da liberdade dele. Esses soberanos
continuavam a ter a sua corte no Rio, para julgar casos, exigir
punições e, ao morrer, eram enterrados com um funeral
elaborado.
(KARASCH, 2000, p.120)

O sujeito escravizado era, desse modo, uma figura dicotômica, que podia ser ao mesmo tempo o rei e o súdito, o comandante e o comandado, o respeitado e o humilhado, o repleto de 'valor significativo' e - 'sem valor econômico', o que 'ainda parece construção' em um momento e 'já é ruína' no segundo sequente. Outra que serve de exemplo

\footnotetext{
4 "Embora a água pudesse prometer liberdade e fuga dos limites da cidade, os marinheiros escravos encontravam muitas vezes apenas paredes de madeira e remos, que os mantinham longe da liberdade dos mares e os separavam de seus companheiros na praia." (KARASCH, 2000, p.104)
} 
a essa existência dupla do escravizado eram os pretos velhos, sobre eles vale apontar:

\begin{abstract}
"O respeito pelos mais velhos era um valor africano básico, e como poucos atingiam idade avançada, os escravos idosos tinham um carisma particular. Os mais jovens dirigiam-se a eles respeitosamente, chamando-os de 'pai' e 'mãe', e trabalhavam em dobro para tornar a existência deles mais fácil. $\mathrm{Da}$ perspectiva africana, idade junto com força religiosa conferiam o status mais alto. Os senhores não valorizavam essas qualidade em um escravo. Os velhos eram colocados em termos de preço, no fim dos inventários. (KARASCH, 2000, p.121)
\end{abstract}

Tudo dependia do ponto de vista pelo qual era observado e, principalmente, a quem ele estava ligado em sua condição de servidão. Essa organização social não caracterizava um arranjo completamente fechado, como já visto, nela era possível alguma mobilidade para alguns afortunados, como também o declínio para os que ultrapassassem os limites incorretos.

Uma boa alegoria dessas relações é uma ilustração de Debret chamada 'Desfile em fila indiana'. Nela vemos,

\begin{abstract}
Saindo de casa, um senhor elegantemente vestido, de 'média fortuna', que lidera uma fila indiana. Por ordem de idade, seguem-no seus filhos; depois, vem sua esposa grávida, seguida de sua escrava parda, de uma ama negra com seu filho de colo e de sua escrava; a seguir, o criado negro do senhor, um escravo aprendiz e, no fim da fila, um menino africano novo, 'escravo de todos os outros'. (KARASCH, 2000, p.113)
\end{abstract}

$\mathrm{Na}$ fila indiana de Debret (Figura 1) encontramos presentes os dois elementos de distinção que atuavam na construção do lugar social dicotômico que o escravizado ocupava. O primeiro deles diz respeito à ligação íntima existente entre o status do senhor e do escravizado, esse era o maior determinante dentro da organização social, tornando as conexões entre o cativo e o soberano uma insígnia de prestígio. Isso fazia com que,

(..) um escravo no fim da hierarquia de uma residência abastada tinha mais prestígio que o primeiro de um imigrante pobre. Se uma escrava fosse comprada por uma família e tivesse um filho do seu senhor, a criança, embora escrava, compartilharia um pouco da posição social atribuída à família.

(KARASCH, 2000, p. 113) 


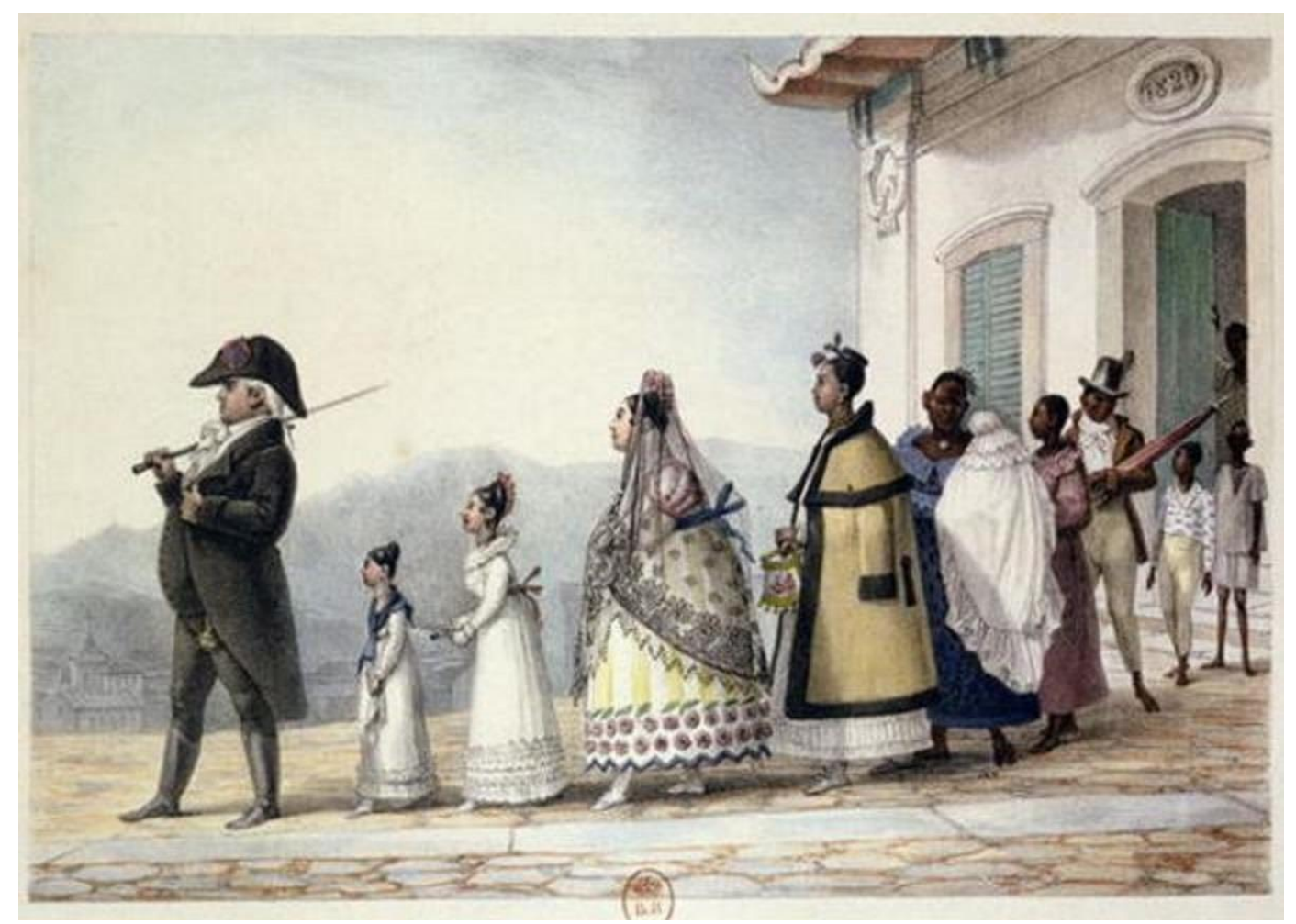

Figura 1. Desfile em fila indiana - Jean-Baptiste Debret (1813-1831)

Fonte: Domínio Público

O segundo aspecto eram as relações que se estabeleciam dentro do próprio grupo de escravizados, este muitas vezes ignorado pelo senhor, mas que ditava grande parte do modo de vida de algumas figuras essenciais, principalmente os líderes religiosos, que inspiravam respeito nos cativos e medo nos seus 'donos', e ocupavam o lugar de maior status social entre os escravizados (Karasch, 2000, p.120). Essas duas forças que legitimavam a posição de um escravizado dentro dos limites sociais impostos pela soberania estavam em interface direta, influenciando e determinando a movimentação do cativo por entre os círculos sociais.

A posição da escravizada parda no início da linha e do menino africano, 'escravo de todos os outros', ao final, nos dá a ver que as características étnicas, estéticas e de ancestralidade também exerciam influência nesse arranjo, onde

Era comum, por exemplo, a visão de escravizados bem trajados dos homens ricos e poderosos desprezando os cativos de donos sem poder, assim como também a cor 'mais escura' e o fato de serem africanos diretos serem critérios que colocavam limites claros à ascensão social. (KARASCH, 2000, p.114) 
Se a estratificação social erguia muros de difícil escalada, quando não impossível, era ainda mais complicado para o escravizado assumir um papel de liderança política sobre as famílias que o mantinham em cativeiro. Isso não significa que não tivessem acesso ao sistema político, visto que o clientelismo também funcionava para os escravizados. Tudo dependia da qualidade da conexão do cativo com a soberania,

\begin{abstract}
Se tivessem o patrono certo, podiam manipular as relações clientelistas com muito mais eficácia do que estrangeiros brancos que não tivessem protetores. Tendo em vista que muitas decisões políticas eram tomadas fora das estruturas institucionais formais e dependiam de 'influência', os escravos podiam influenciar algumas decisões. Ademais podiam até ver seus netos, se nascidos livres ou de cor mais clara, gozar de mobilidade política e entrar nos escalões mais baixos do governo.(KARASCH, 2000, p.121)
\end{abstract}

Mesmo conseguindo exercer alguma influência dentro de certos limites não havia dúvida de que quem tinha o poder de decisão eram os 'homens brancos de famílias de elite'. No mais, era possível identificar 'gente livre de cor' ocupando posições de autoridade política, mesmo que os traços de sua origem étnica fossem perceptíveis, esses sujeitos não eram escravizados e nem eram considerados 'pessoas de cor'.

Essa identificação vem dos relatos de viajantes que registravam imensa surpresa ao identificar a presença de membros da política brasileira 'tingidos' ou 'de cor'. Porém, tais observações podem não corresponder com a realidade, visto que

Os de fora [estrangeiros], vendo um nível significativo de
mobilidade social dos descendentes de escravos concluíam
que não havia preconceito racial no Brasil. Do ponto de vista de
um escravo, as realidades sociais eram bem diferentes. Os
homens importantes 'tingidos' eram brancos no contexto
daquele período. Os homens de cor que o viajante Seidler
observou na Câmara de Deputados vinham da Bahia e de
Pernambuco, de tradicionais famílias nordestinas. Enquanto os
estrangeiros poderiam tratá-los como 'de cor', a elite da
sociedade os via como membros proeminentes de famílias
abastadas. (KARASCH, 2000, p.123)

A estrutura social tornava impossível a ascensão de um escravizado ao ambiente político de forma direta, contando apenas com seu poder de influência (se houvesse) que minimamente garantia um acesso restrito a pequenos favores concedidos pela soberania branca. Sendo assim, 


\begin{abstract}
Olhando para as ocupações de homens de cor, estrangeiros e brancos em 1834, os escravos africanos deviam reconhecer que o acesso a papéis de decisão no sistema político era impossível para eles e improvável para negros livres. Como libertos, podiam servir apenas de eleitores no nível mais baixo. Se seus descendentes fossem de cor mais clara, poderiam estar entre a pequena minoria de gente de cor a atingir altos cargos. Seus filhos ou, com maior probabilidade, descendentes remotos de cor ainda mais clara, poderiam começar a longa ascensão da pirâmide social, mas somente enquanto 'brancos' e nos termos da sociedade branca. Porém, na primeira metade do século XIX, o sistema político nunca estava aberto a escravos enquanto escravos em papéis de decisão sobre seus donos ou aos seus descendentes que não tivessem 'branqueado' em cor e cultura.
\end{abstract}

(KARASCH, 2000, p.125)

Se as portas da política estavam fechadas aos negro-africanos escravizados ou livres, as Forças Armadas e a Igreja Católica eram mais receptivas. Indo contra a prática de algumas sociedades escravistas, no Rio de Janeiro 'armar escravos era uma prática aceita'. O Brasil adquiriu longa experiência com escravizados-soldados, que já atuavam desde o século $\mathrm{XVI}$, nas conquistas coloniais onde os cativos defenderam o império português.

Ao entrar no século XIX as classes abastadas já não valorizavam a atividade dos soldados de infantaria, dedicando-se mais às chefias de milícias locais e regionais. Os escravizados também estavam presentes em tais milícias, sendo até mesmo um caminho com boas possibilidades para os mais ambiciosos, que atuavam em diversas áreas, indo desde carregadores de sombrinhas para os seus senhores, até componentes de grupos inteiramente formado por 'homens de cor', que ficaram conhecidos como Terços dos Pardos, especialmente importantes antes de 1808 (Karasch, 2000, p.125).

No exército regular foi registrado um aumento no número de pardos e escravizados presentes, no século XIX, tanto desempenhando papéis inferiores como atuando diretamente na luta armada. Para os cativos tal trabalho poderia simbolizar a liberdade, visto que esse era o pagamento dado a alguns pelos seus serviços, como também poderia significar um trabalho forçado imposto pelo governo nacional contra a sua vontade e a do seu senhor. 
Alguns apresentavam-se como voluntários para o trabalho militar para fugir dos castigos brutais aos quais eram expostos, assim como alguns senhores 'doavam' seus cativos como forma de livrar-se dos que estavam doentes ou eram rebeldes. Os negro-africanos também poderiam ser empregados na polícia militar, que desempenhava função policial, e incluíam as funções de,

(...) capitães-do-mato, caçadores de escravos fugidos, que eram negros, mulatos, índios e brancos. Utilizavam-se homens de cor e ex-escravos até mesmo na atividade de controle policial de escravos e libertos.

(KARASCH, 2000, p.129)

A presença da população cativa exercendo atividades de controle e vigilância expõe a estratégia da sociedade hierárquica do Rio de Janeiro de criação de um 'grupo de interesse' dentro da comunidade negra, que sedimentava a ideia de que era possível caminhar pelas 'estradas da preferência' desde que estivessem dispostos a manter os seus 'conterrâneos na linha'. Ou seja, mobilidade social em troca de serviço leal.

Embora essa 'preferência' pudesse sugerir alguma consideração pelos oficiais negro-africanos, o objetivo estava mais ligado ao desejo de garantir a eficiência do trabalho dos cativos e utilizá-los a favor da vontade da soberania, mantendo o seu status de subalterno dentro da estrutura. Prova disso é o fato de que,

\begin{abstract}
Mesmo os oficiais negros mais capazes recebiam apenas as ordens militares menores e não podiam aspirar às mais importantes, ostentadas pelos oficiais da elite. Ademais, eram oficiais somente dentro de seus regimentos enquanto os mulatos com as conexões familiares certas podiam aspirar a servir no exército regular, os negros estavam longe disso (...) Em parte, o censo de 1834 confirma que poucos negros tinham posição militar: havia apenas quatro negros 'militares' e 35 homens navais; os pardos obtinham mais sucesso, com 111 'militares' e 72 homens navais. Os 1440 brancos brasileiros superavam de longe os homens de cor na classificação 'militares'. Como sempre, uns poucos talentosos tinham conseguido romper a barreira e entrar nos quartéis, mas a vasta maioria ainda estava de fora. (KARASCH, 2000, p.130)
\end{abstract}

O mesmo caráter preconceituoso e discriminador era encontrado na Igreja Católica, que também utilizava de critérios étnicos-raciais, para organizar a estratificação social no interior das suas práticas. Aos negroafricanos livres era permitida a atuação em posições de liderança, os 
escravizados por sua vez só podiam participar como leigos e membros de irmandade religiosa.

Por vontade de seus soberanos todos os escravizados eram batizados e, por isso, eram considerados católicos e pertenciam a alguma congregação. A eles era concedida a permissão de entrar e rezar em qualquer igreja da cidade, assim como os brancos também podiam frequentar igrejas de negros-africanos, mas mesmo com essa condição ainda existiam muitas segregações na prática religiosa. Não havia igualdade dentro da Igreja Católica, o que barrava a mobilidade social dos escravizados. Prova disso era o que acontecia nas irmandades,

\begin{abstract}
Uma vez que havia poucos padres no Brasil durante o período colonial, boa parte da sustentação da Igreja ficara a cargo de associações religiosas leigas, conhecidas como irmandades, que reuniam homens e mulheres. Na ausência de padres, os irmãos leigos organizavam as comunidades, levantavam dinheiro e construíam capelas e igrejas, promoviam procissões em dias santos para seus santos patronos, conduziam orações e rituais, coletavam esmolas, enterravam os mortos e rezavam por eles.

(...)

No Rio do século XIX, as irmandades eram hierárquicas e socialmente estratificadas e exclusivas de determinados grupos. Embora houvesse um lugar para todos dentro da Igreja, algumas irmandades eram 'superiores' a outras. Como era de se esperar, as irmandades negras eram de status baixo. A documentação é eloquente no que se refere à falta de lar das irmandades negras pobres, que tinham de mudar de igreja com frequência, às vezes por causa de discriminação. Acima delas, em status, estavam as irmandades de pardos, e no topo, as irmandades brancas.
\end{abstract}

(KARASCH, 2000, p.130 e 131)

A inferioridade de tais irmandades não se dava somente por conta dos seus frequentadores, vinha também pela ausência de construções próprias, tornando-as dependentes diretas de outras irmandades que possuíam templos e concediam um espaço secundário, geralmente uma capela lateral, para receber as atividades das irmandades dos negroafricanos. A incapacidade financeira de materializar a sua fé tornava-se um obstáculo que embarreirava o desenvolvimento e a emancipação dessas organizações religiosas.

Algumas irmandades conseguiram tornar-se economicamente autossuficientes e com grande sacrifício por parte dos escravizados, 
libertos e 'gente livre de cor' e levantaram dinheiro para construir suas próprias capelas ou igrejas. São elas:

\begin{abstract}
Nossa Senhora do rosário e São Benedito, na rua Uruguaiana; Nossa Senhora da Lampadosa, na rua da Lampadosa (atual Luís de Camões); São Gonçalo Garcia, na rua da Alfândega; Santa Ifigênia e Santo Elesbão, na quadra entre a avenida Passos e a rua Gonçalves Ledo; São Domingos, que foi derrubada quando a avenida Presidente Vargas foi aberta; a capela de Santa Ana, no campo de Santana; Santo Antônio dos Pobres, na rua dos Inválidos, e a igreja do Hospício, na rua do Rosário.
\end{abstract}

(KARASCH, 2000, p.132)

Esses locais religiosos também possuíam diversas funções, que iam desde o enterramento de negro-africanos em seu território seguindo rituais próprios de matriz africana e que também coletavam donativos para membros pobres, compravam a liberdade dos cativos com suas economias e guardavam o dinheiro dos seus membros escravizados, caso o seu senhor quisesse confiscá-lo. Eram nesses espaços também que ocorriam cultos dedicados aos santos negros, como São Benedito, Santo Elesbão, Santa Ifigênia e o rei mago Baltasar, que eram ignorados pela soberania branca.

Os sacerdotes negro-africanos e pardos também eram igualmente ignorados dentro da Igreja Católica,

\begin{abstract}
Somente poucos negros excepcionais e um pouco mais de mulatos conseguiam entrar nos escalões mais baixos da hierarquia, tornando-se padres. Eram até admitidos em mosteiros, mas aparentemente não em conventos, exceto se a mulher pudesse passar por 'branca'. Como instituição hierárquica, a igreja carioca tinha um lugar para os escravos embaixo -, mas também prometia mobilidade a uns poucos de seus filhos e uma vida melhor na 'próxima vida'.
\end{abstract}

(KARASCH, 2000, p.137)

Um dos grandes problemas das irmandades negro-africanas era a falta de recursos financeiros, isso era reflexo da situação de exploração ao qual os seus irmanados eram mantidos na colônia. Os escravizados não exerciam papel decisivo na economia da cidade, sua função básica era proporcionar mão de obra para o desenvolvimento econômico dos soberanos. No entanto, mesmo na condição objetal que ocupavam, alguns escravizados conseguiam produzir esquemas paralelos de comércio baseados na agricultura de subsistência, caça e pesca. Essa 
organização era mantida por um 'sistema comercial', que tinha início nos campos e nos subúrbios ao redor da cidade. (Karasch, 2000, p.140)

Nesses espaços era feito o plantio de frutas e verduras, também eram criadas galinhas, patos, porcos e cabras, muitas vezes nos quintais dos próprios escravizados, ou mesmo dos seus senhores. Os itens eram vendidos na cidade, onde os cativos já possuíam seus intermediários que compravam e vendiam produtos por preços diferenciados a fim de produzir uma renda extra que era recolhida e utilizada pelo cativo em seus planos pessoais, que muitas vezes consistiam na compra de mais comida, roupas, artigos religiosos e até mesmo a sua liberdade. Assim, Enquanto as mulheres tomavam conta do negócio de produtor
agrícolas, os escravos homens negociavam produtos animais.
Todos os dias, levavam latas de milho ou de frangos sobre a
cabeça, ou conduziam porcos, cabras e gado das áreas rurais
para serem vendidos por conta própria, mas a maioria para ser
entregue a matadouros e açougues. Os pescadores saíam em
barcos pequenos e canoas e violavam os monopólios de
pesca, vendendo peixe aos pores por preços abaixo do
mercado. Os trabalhadores de matadouros obtinham
regulamente vísceras e restos de carne e os vendiam abaixo
do preço dos açougues licenciados enquanto que vendedores
de leite compensavam o que vendiam ilegalmente diluindo seu
produto legal em água.
(KARASCH, 2000, p.140)

Alguns escravizados conseguiram prosperar dentro desse sistema comercial alternativo, investindo em negócios, terras e propriedades. Os mais ricos auxiliavam os demais, inserindo-os nesse sistema comercial que ocupava as ruas das freguesias urbanas ou como mascates no interior. A existência desse fenômeno é uma das formas de vislumbrar, acima de tudo, a resistência e a luta por uma sobrevivência mais digna dentro desse mundo de privações e interdições.

Vivendo nesse ambiente de restrições, onde o espaço estava totalmente controlado, existia um lugar em que o escravizado podia ser livre: nos seus sonhos. Sonhos de ação, de luta, de liberdade; sonhos musculares, como nos diz Fanon. O sonho de um dia pular todas as barreiras e conseguir completar a construção de si mesmo, de não mais ver seu mundo arruinado no primeiro olhar inquisidor do sujeito que diz ser seu dono. Sonho de não ser obrigado a construir nada, se não quiser. Sonho de poder não querer. Já dizia Fanon (1966), 'Sonho que salto, que 
nado, que corro, que brinco. Sonho que estalo de riso, atravessei o rio de um salto'. Sonho de esticar a perna e cruzar um continente inteiro, de extrapolar o limite dos tendões. Sonho de transbordar as fronteiras da pele, as possibilidades do corpo catalogado, de não se deixar medir pelas réguas alheias, de estar livre das correntes e poder habitar o seu próprio corpo, o seu mundo. 


\section{O mercado de carne da carne do mundo}

As noites deviam parecer intermináveis. As longas horas de caminhadas, quer fossem guiadas pelo teto verde das florestas da savana ou percorrendo o tapete dourado das franjas do deserto, significavam o início de um trajeto rumo ao desconhecido, no interior da África. Milhões de pés percorreram esses caminhos. Rumavam por entre a dor, as pedras, o cansaço, os pântanos, a desilusão, as árvores e a desonra. Presos uns aos outros por correntes e ferros, mas também unidos por um mesmo destino, esses corpos vagavam em direção ao mar. Mesmo que não soubessem por onde seguir, os homens que os conduziam sabiam onde queriam chegar e mesmo que compartilhassem as crenças ou até origens entre si; os vencedores podiam decidir sobre a vida dos que perdiam. Assim seguiam até alcançar os portos em que, sendo entregues aos devidos comerciantes, eram redistribuídos e organizados de modo a saciar a fome dos leviatãs de madeira que, abrindo suas bocarras, engoliam centenas de homens e mulheres em cada porto que ancoravam. Após vencidas as burocracias e responsabilidades fiscais, já com seus estômagos repletos de vidas humanas, esses monstros lançavam-se nos oceanos. Domados por marujos e capitães, estas feras podiam cruzar o oceano em jornadas que duravam mais de 50 dias. Tanto os homens do mar quanto os que aguardavam ansiosos em terra visavam o maior lucro possível em toda essa empreitada e, para tal, tinham dois objetivos principais: vencer as distâncias continentais no menor tempo e com a maior quantidade de carga viva e saudável que fosse possível.

Talvez o mar se tornara mais salgado pela quantidade de lágrimas e de suor derramados nessas viagens. Talvez a água tenha ficado mais escura pela imensa quantidade de sangue que pingou em seu manto azul. Talvez o mar tenha ficado mais raso, após tantos corpos serem arremessados em suas profundezas. Enfim, as consequências dessas travessias ainda não conseguiram ser medidas por completo, seja no Atlântico, no Índico ou em qualquer outro canto da Terra. O que nos é permitido confrontar é o fato determinante de que $40 \%$ dos 10,7 milhões de africanos sequestrados em seu continente nesse processo de 
comercialização escravista foram destinados aos portos do Brasil, onde deste número $60 \%$ chegaram na cidade do Rio de Janeiro. Os desembarcados na bela cidade tropical tinham como destinado, após 1774 e até 1830, o 'complexo comercial do Valongo', espaço instituído pelo poder público como único local onde era permitida a prática de comércio de escravizados na cidade.

Como parte fundamental da história do comércio escravista no mundo, o 'complexo comercial do Valongo' era a principal porta de entrada para um mundo completamente novo e que precisava ser rapidamente apreendido e decodificado pelo cativo recém-chegado. Porém, antes de aportar em solo carioca, muitas etapas do processo de produção do escravizado já tinham sido realizadas desde a captura dos indivíduos em África até o seu desembarque na América.

Iremos nos ater por alguns instantes nesses momentos anteriores à chegada dos africanos no Rio de Janeiro, pois desvelam um pouco do intricado sistema de comércio mundial de cativos no qual o Valongo fazia parte, mas principalmente por que tais informações constituem parte importantíssima da trajetória enfrentada pelo sujeito central de todas as narrativas que tangem esse comércio e seus desdobramentos: o escravizado.

Precisaremos retornar de onde iniciamos. Na verdade, é preciso fazer o retorno para antes das caminhadas e das noites eternas que levavam para fora do continente africano. O ponto inicial de todo o processo era a captura.

$\mathrm{Na}$ África os principais pontos de apresamento de cativos eram as sociedades que ocupavam o interior do continente africano, áreas essas que não eram acessadas em larga escala pelos europeus, como nos aponta Alberto da Costa e Silva (1994),

$\mathrm{Na}$ realidade, a África só abria para o exterior um pouco da casca. Assim fôra desde sempre. O estrangeiro se parava no Sudd, ao sul da Núbia, em Ualata, Gana, Gaô, Tombuctu e outros caravançarais do Sael, em Quiloa, Mombaça, Angoche, Zanzibar e iguais feitorias do Índico e, desde a abertura do Atlântico, nos entrepostos e forros de Bissau, El Mina, Ajudá, Luanda, Benguela e tantos mais. Até meados do século XIX, o europeu só avançava alguns passos para fora dos muros e paliçadas em algumas poucas áreas, e na maior parte dos 
casos, com o consentimento e o apoio dos africanos, ou sob sua vigilância. (COSTA E SILVA, 1994, p.21)

Essa característica de ocupação torna-se fundamental para a compreensão dos métodos de captura de cativos e de como, devido as mudanças nas dinâmicas internas do continente, estas práticas foram sofrendo alterações. Inicialmente os europeus realizavam as suas próprias expedições de captura, tendo como alvo as sociedades da costa da África Ocidental, sendo que

A maioria dos africanos importados pela Europa, ilhas do Atlântico e América durante o século $X V I$ parece ter se originado dos primeiros oitenta quilômetros entre a Costa Atlântica e o interior. Dado que, por sua vez, mostra como era restrito o eixo inicial de ação do comércio negreiro (...) Este tráfico interno, realizado por europeus, contribui substancialmente para a expansão das relações escravistas em amplas áreas do litoral do Oeste africano.

(FLORENTINO, 1997, p.89)

Nesse período o método de captura consistia basicamente em sequestros elaborados pelos portugueses, onde

(...) lançavam-se violentamente contra as populações das costas e das pequenas ilhas. É necessário entender que a Costa Atlântica era a periferia das sociedades. Nenhum europeu teria sucesso se acometesse um reino do interior do continente, pois eram sociedades altamente organizadas. As populações das margens do Atlântico, entretanto, constituíamse de pescadores, marisqueiras e pequenos agricultores que sofreram a feroz violência dos europeus em acontecimentos de verdadeiro terror (...) Eventos como esses foram comuns nas ilhas de Cerina, Nar, Tiber, como também nas regiões que na atualidade são os países Senegal, Guiné-Bissau, Serra Leoa, além de outras partes do continente.

(ACOSTA-LEYVA, 2017, p.95)

Conquistando espaço através da violência, os portugueses estabeleceram-se na região localizada ao norte do rio Senegal, transformando a Alta Guiné no mais importante núcleo de captura de cativos antes do século XVII (Florentino, 1997, p.84). Mesmo orquestrando com suas próprias mãos os sequestros de africanos para a inserção na rota do seu comércio escravista, os portugueses nessa época já haviam estabelecido quase que por completo uma outra prática de obtenção de cativos baseado na troca. 
Este modelo predominou por toda o período do tráfico escravista para a América, constituindo-se como

(...) verdadeiros enclaves litorâneos, onde, a partir de alianças políticas, comerciais e militares com as autoridades nativas, trocavam-se manufaturados europeus ou tabaco e aguardente americano por cativos. (FLORENTINO, 1997, p.85)

Esse método que substituiu a captura direta pela troca 'era resultado da forte resistência das unidades políticas dos povos africanos', conforme aponta Acosta-leyva, que complementa,

Como a condição de enfrentamento não ofereceu os resultados esperados, então [os portugueses] começaram a se integrar no comércio que há séculos direcionava-se para o Mediterrâneo via deserto do Saara. Compravam ouro, advindo do interior, especialmente de Bambuk e Buré, e compravam escravos em outros lugares da costa. (ACOSTA-LEYVA, 2017, p.96)

Esta rede de comércio, por sua vez, era abastecida por um segundo método de captura, este operado pelas sociedades africanas. Segundo Florentino (1997),

(...) existem indicações precisas de que, desde o início, as guerras conformavam o instrumento básico por meio do qual os homens eram transformados em escravos e vendidos no litoral, o que permite a alguns estudiosos estimarem que, ao longo de toda a era do tráfico pelo Atlântico, cerca de três quartos dos africanos vendidos para as Américas resultassem de guerras. Os enfrentamentos bélicos encontravam motivações no interior das próprias estruturas econômicas e sociais vigentes em cada região, cujos elementos de conflito eram suficientemente fortes para suprir, desde a Antiguidade, e em particular desde a expansão islâmica, a demanda mediterrânea por escravos. (FLORENTINO, 1997, p.85)

Os enfrentamentos que produziam os cativos podiam ter diversas naturezas. Desde questões internas de disputas territoriais entre comunidades 'sem controle estatal' até grandes conflitos que envolviam ‘Estados já constituídos e/ou em formação'(Florentino, 1997, p.85).

Destes embates, entre os espólios materiais e as conquistas territoriais e tributárias, encontravam-se os prisioneiros, que podiam ser incorporados como escravizados no interior das comunidades vitoriosas, ou redirecionados para o comércio com os traficantes do litoral. Esse intercâmbio das elites nativas com os comerciantes euro-americanos possibilitaram a incorporação de novos produtos manufaturados que tiveram papel determinante na dinâmica interna do continente. Desse modo, 
Tal qual sucedera, vários séculos antes, com a chegada do cavalo como animal de guerra às estepes ressequidas e às savanas da África Ocidental, as armas de fogo alteraram as táticas de guerra e as relações de força interafricanas. Cresceu o poder centralizador dos reis, que monopolizavam o comércio externo e, portanto, o acesso aos mosquetes e à pólvora. Novos estados surgiram de chefias que controlavam os caminhos para o mar e outros se consolidaram e expandiram, muitas vezes sobre a base de um intenso sentimento nacional. (COSTA E SILVA, 1994, p.25)

Essa estrutura de fortalecimento bélico através do comércio de cativos foi a principal via tomada por muitas sociedades em vias de expansão nos séculos seguintes, como nos diz Florentino, Não é por acaso que os séculos XVII e XVIII tenham
representado o apogeu dos grandes estados interioranos da
Baixa Guiné (Daomé, Oyo, Ardra, Ashante, dentre outros), os
quais, por meio do controle das rotas que do interior
alcançavam a costa, dominaram o fluxo de cativos para a
América. Em primeiro lugar havia a conquista dos reinos
costeiros pelos Estados interioranos, o que permitiu a estes
dominar o fluxo de homens ao sul da África Ocidental. O
segundo mecanismo surgiu a partir do fortalecimento de muitos
destes Estados interioranos, que desenvolveram meios
próprios de comercialização.

(FLORENTINO, 1997, p.88)

Um circuito fechado formara-se a partir da rede de interesses entre as sociedades africanas e os comerciantes euro-americanos. Enquanto os traficantes europeus tinham a sua demanda por escravizados atendida, os grupos dominantes viam nessa relação uma maneira de fortalecer seu poder, incorporando povos tributários e cativos. $\mathrm{O}$ acesso a bens manufaturados aumentava a capacidade de produção de escravizados por parte destas sociedades que dominavam as redes de troca e que consequentemente também controlavam a circulação do principal item de escambo: vidas humanas. Com o passar dos anos, seria sentida uma mudança nesse paradigma de embate e produção de cativos, como podemos ver a seguir,

Um novo incremento da economia americana, agora no século XVIII, teve por consequências tanto a intensificação da competição entre traficantes de diversas nações na costa quanto a maior interiorização das fontes de produção de escravos. A partir da segunda metade do século, o atendimento da demanda e além-mar esteve intimamente relacionado com os primeiros ensaios da Jihad (guerra santa) islâmica, levada a cabo por Estados interioranos contra os pagãos. A guerra era comandada por autoridades e 
aristocracias militares regionais, fortalecidas pelo comércio com o Mediterrâneo e o Atlântico, especialmente contra comunidades mais débeis, o que não excluía os embates entre Estados já fortemente assentados. Neste último caso, apensar de estar proibida a escravização de muçulmanos por muçulmanos, ela era comum. Os sequestros, menos usuais, eram realizados por pequenos grupos armados, que atacavam cultivadores ou pessoas em trânsito. Tratava-se de uma atividade duramente castigada pelas autoridades estatais, o que restringia a atuação dos sequestradores, principalmente à área de fronteira entre os reinos e às rotas fechadas. (FLORENTINO, 1997, p.89)

A transição para o século XVIII, por sua vez, marcou o início da intensificação do comércio escravista pela África Central Atlântica que se prolonga até o século XIX, com destaque para o período de 1760-1830.

É importante salientar que diversas regiões do continente africano forneceram cativos para o mercado escravista do Rio de Janeiro. Com base nos registros de entradas das embarcações na cidade carioca, no período de 1795 a 1830, Manolo Florentino aponta que a África Central Atlântica teve a participação mais ostensiva durante todo o período, com destaque para as regiões do Congo e Angola. $O$ historiador não desconsidera a forte participação da África Oriental, através da Ilha de Moçambique e dos portos do Sul, em especial de Quelimane, que tiveram maiores índices de exportação após 1811, porém estes não superam os números da região Central Atlântica. A África Ocidental, mostra-se como uma rota historicamente sem maior importância, desaparecendo dos registros em $1816^{5}$.

Nesse período a captura através dos enfrentamentos bélicos também é favorecida por 'especificidades ecológicas' que, conforme afirma Florentino, refletiam-se nas formações sociais e econômicas de modo pungente fazendo com que

(...) qualquer fator desestabilizador (secas, pestes e mesmo a ação de traficantes) detonasse uma intensa competição por recursos, que se traduzia em conflitos armados. A combinação milenar entre poucos e localizados espaços capazes de sustentar continuamente as populações humanas, por um lado, e as recorrentes secas que explodiam de sete em sete anos, por outro, transformaram a área bantu do Atlântico em cenário ideal para a produção de cativos. $\mathrm{O}$ ciclo recorrente de secas e

\footnotetext{
${ }^{5}$ Para uma visão mais aprofundada é sugerida a leitura de 'As fontes maiores: Congo e Angola' Florentino (1997).
} 
a indução exterior criava ou dependendo da região simplesmente tornavam mais contundentes os enfrentamentos entre Estados, etnias, classes sociais e grupos domésticos, e com eles se aumentava a oferta de escravos. (FLORENTINO, 1997, p.97)

Como visto até o momento os métodos de captura eram muitos e incluíam diversas motivações e práticas, principalmente se considerarmos o tempo de vigência do comércio escravista e da quantidade de pessoas envolvidas nesses processos. O que é importante ressaltar mais uma vez é o papel estruturante que as relações internas das sociedades africanas tiveram no que tangia a captura dos cativos e de como essas práticas funcionavam como marcadores de diferenciação entre estas comunidades nativas. Sobre isso Florentino nos diz que,

\begin{abstract}
Não causa surpresa, portanto, que durante o auge do tráfico a maior parte das sociedades africanas sem Estado estivessem situadas fora dos principais eixos do comércio negreiro (...) à aquisição de bens no litoral correspondia o fortalecimento político e econômico dos grupos dominantes nativos. Acentuava-se a diferenciação social entre classes e frações de classes, entre as etnias, Estados e mesmo no interior da comunidade doméstica.
\end{abstract}

(FLORENTINO, 1997, p.101)

O aumento das assimetrias nas relações de poder e nas organizações sociais nativas também resultou no acréscimo da utilização de escravizados no interior dessas comunidades. Porém a escravização que, antes do vínculo com o comércio europeu, não constituía a base da economia das sociedades africanas e possuía um caráter doméstico, passa cada vez mais a tornar-se mercantil. Certamente o lugar social do escravizado dentro dessas sociedades passava a ser outro, bem como a importância da captura e da sua distribuição, como fica evidente nas palavras de Acosta-leyva (2015),

Selma Pantoja concorda que "originalmente [em sociedades baseadas na linhagem], o recurso aos escravos e escravidão era um meio de excluir os elementos nocivos à comunidade, como uma maneira de reforçar a coesão social e assegurar a estabilidade da sociedade". E em um segundo momento o tráfico (e a escravidão) transformou-se numa prática indispensável para a sobrevivência das sociedades envolvidas como modo de sustentação das diferenças sociais e econômicas e, no âmago dessas sociedades para a distinção social entre os indivíduos e fortalecimento do grupo que estava no comando.

(ACOSTA-LEYVA, 2015. p.18) 
Sendo a captura o momento que iniciava o processo de 'produção do escravizado', o segundo passo era a sua distribuição e comercialização ainda em solo africano. Saídos de sua comunidade nativa, os cativos eram conduzidos em caminhadas que podiam durar semanas, em direção aos centros que detinham os monopólios comerciais, onde iriam compor a quantia reservada pelos traficantes (pumbeiros, aviados, funantes ou sertanejos) que vinham da costa para realizar as transações diretamente com as autoridades interioranas. Para evitar os gastos com a manutenção dos cativos os comerciantes locais não estocavam a mercadoria humana, desse modo procediam como exemplifica Florentino, ao citar o caso dos traficantes angolanos,

\begin{abstract}
Esperava-se pela chegada dos sertanejos para acordar um determinado número de peças em troca de mercadorias - que se recebia adiantadamente - e só então se enviavam agentes em busca de escravos nas áreas fronteiriças. Transferidos para a responsabilidade dos sertanejos, que deveriam mantê-los, pelo menos em parte, os grupos de cativos (libambos ou quibucas) iam crescendo até atingir o número requerido pelos mercadores dos portos angolanos.

(FLORENTINO, 1997, p.109)
\end{abstract}

Cumprida essa parte inicial, e trocando de lugar com os manufaturados, os cativos partiam por mais alguns meses de caminhada com destino a cidades costeiras. Era comum nesses trajetos acontecerem fugas, mortes ou até mesmo a prática do reviro, que consistia na venda de algumas peças a outros compradores que surgiam durante o caminho de volta para as regiões costeiras. No reviro, o valor angariado pelo traficante compensava os tributos que deveriam ser prestados ao mercador a quem destinava-se os cativos ou, no caso de perdas, o valor do reviro saldava o débito com os credores que financiavam as suas expedições.

Para o cativo, sobreviver a todo esse processo de caminhadas extenuantes e de diversas outras violências que ocorriam até o momento do seu embarque nos navios tumbeiros tornava-se o primeiro desafio da sua nova condição de vida. Os índices de mortalidade ainda no continente africano eram muito altos, como podemos ver a seguir,

Havia, de início, as mortes durante o longo trajeto entre as zonas da captura do interior e a costa africana, que se somavam às ocorridas durante a espera nos barracões e 
portos. Joseph Miller afirma que provavelmente $40 \%$ dos negros escravizados em Angola pereciam durante 0 deslocamento até o litoral, onde outros $10 \%$ ou $20 \%$ morriam antes de serem embarcados. Em geral, pois, cerca da metade do contingente de cativos poderia perecer ainda em solo africano. Outro estudioso, Antônio Carreira buscou contabilizar as perdas sofridas pela Companhia Geral do Grão-Pará e Maranhão na sua atuação em Luanda e Benguela entre 1756 e 1781. Da documentação da companhia, descoberta em arquivos de Lisboa, depreende-se que, entre escravos falecidos nos barracões e evadidos, perdeu-se $6 \%$ dos 8854 cativos adquiridos - outros $1 \%$ foram deixados nos portos de embarque por estarem doentes.

(FLORENTINO, 1997, p.140)

Já ancorados nos portos africanos, os navios negreiros ficavam uma média de 4,5 a 5,5 meses aguardando a sua lotação, porém esse tempo era variável. No caso dos portos de Moçambique, por exemplo, essa média era reduzida para quatro ou cinco meses. A agilidade no atendimento da demanda dos navios era sinônimo de menores despesas de manutenção da expedição e consequentemente maiores lucros. Durante esse tempo de espera das embarcações os cativos disponíveis podiam tanto já serem embarcados como também acondicionados em armazéns, onde também estavam expostos a diversos perigos. Roubos durante esse período eram comuns,

Foi o que ocorreu em fevereiro de 1827 quando o negreiro Estrela do Mar, consignado a Joaquim de Mattos Costa, foi roubado em 213 escravos dentro do próprio porto de Molembo. O mesmo se deu com traficantes como Felipe Ribeiro da Cunha, em Molembo (1828), e Joaquim Martins Mourão, em Cabinda (1829), roubados em 188 e 103 escravos, respectivamente antes de zarpar.

(FLORENTINO, 1997, p.141)

Essas informações comprovam o cenário de extrema tensão encarado pelos africanos aprisionados que aguardavam nos portos em que, além de altamente debilitados após longas caminhadas e tratados de forma degradante pelos traficantes, eram mantidos por meses até partirem. O destino de centenas de homens, mulheres e crianças, estavam completamente entregues aos interesses e necessidades de terceiros que, ao reduzirem suas vidas ao grau máximo de objetificação, mantinham com os cativos relações extremamente violentas e predatórias. Dentro e fora das embarcações, os escravizados eram tratados como qualquer outra carga que estivesse sendo transportada, 
com a única diferença que deveria ser mantida viva e controlada, por isso precisava de tratamentos específicos ${ }^{6}$.

Um desses tratamentos básicos era a alimentação, na maioria das vezes realizada com produtos trazidos pelos traficantes de seus portos de origem, como comprovam os seguintes dados,

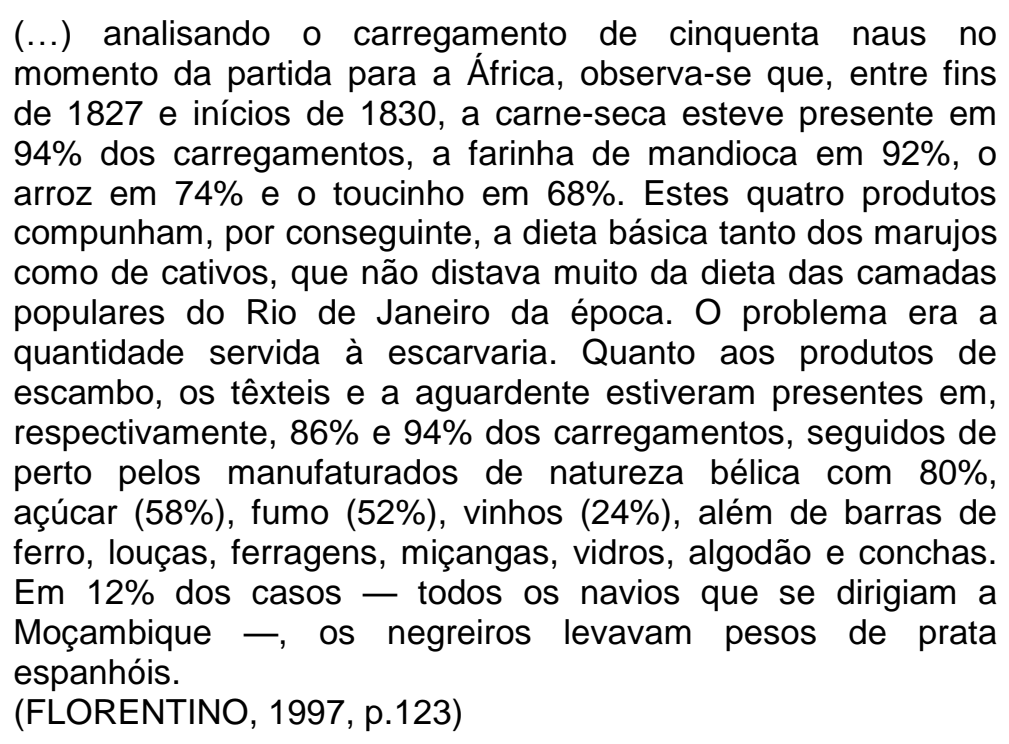

Era só após a distribuição dos itens de escambo e a subsequente composição da carga de cativos que os navios tumbeiros finalmente ganhavam o mar, ofuscando o brilho das estrelas na escuridão dos porões pútridos e tornando as noites ainda mais sombrias.

São inúmeras as representações que nos dão a ver como era a vida dos africanos no interior das embarcações. Talvez a figura mais emblemática dessa narrativa seja a gravura de 1835, Negros no fundo do porão, do pintor francês Johann Moritz Rugendas, que constantemente preenche os livros de História com a clássica representação de um porão super lotado de homens e mulheres africanos, com aspecto abatido e visivelmente debilitados. Outro relato importante é o do inglês Robert Walsh que, em 1828, descreveu o porão do negreiro brasileiro Veloz, apreendido ainda no continente africano. Em suas palavras encontramos o seguinte cenário,

Os compartimentos destinados aos prisioneiros, de um metro de altura, obrigavam os adultos a se conservarem agachados

\footnotetext{
6 "Não se deve esquecer, porém, que o escravo constituía em uma mercadoria literalmente perecível, dado constantemente levado em conta pela ação empresarial." (FLORENTINO, 1997, p.141)
} 
(...) como eram muitos, vinham todos sentados entre as pernas um dos outros, de modo que a disposição da carga era a de compactas fileiras de indivíduos. Luz quase não havia, nem ventilação.

(WALSH, 1985, p.212)

Ainda acompanhando 0 rastro de relatos célebres acerca das condições com que se encontravam os cativos nos negreiros, temos a narrativa de outro inglês, o reverendo Pascoe Grenfell Hill que, em 1843, subiu a bordo do negreiro Progresso que havia sido apreendido em Moçambique. A embarcação tinha 140 toneladas com um convés de 37 pés de comprimento, que concentrava em seu porão os cativos aprisionados. O historiador Jaime Rodrigues (2000) apresenta um resumo sobre o relato de Hill,

Após a apreensão do navio, a tempestade que se anunciava no horizonte confirmou a previsão de um marinheiro espanhol da tripulação negreira de que 'mañana habrá machos muertos'; de fato, foram encontrados 54 cadáveres no porão, no dia seguinte, esmagados e mutilados no balanço provocado pelo temporal. Alguns dos que viviam estavam enfraquecidos por doenças, outros machucados e ensanguentados. Nas palavras do reverendo, 'o mundo não poderia apresentar espetáculo mais chocante do que o que ocorria a bordo deste navio'. Na avaliação de Antônio, o espanhol, 'se os negros estivesse bem acomodados não morreriam'.

(RODRIGUES, 2000, p.151)

Apresentando um outro ponto de vista sobre a condição dos cativos nos navios tumbeiros, temos o relato de Emeric Vidal, também apresentado por Rodrigues (2000),

\begin{abstract}
Uma exceção notável é a obra de Emeric Vidal, Embarcação de escravos, de 1834: num pequeno veleiro de dois mastros, tomado à grande distância de modo a confrontar a fragilidade do navio com a imensidão do oceano, os negros estão no convés, amontados, formando uma massa humana indistinta. (RODRIGUES, 2000, p.153)
\end{abstract}

Ao mobilizar todas essas representações clássicas e igualmente distintas, da realidade dos navios que transportavam os africanos, Rodrigues aponta para uma 'cristalização' de certas imagens que fixaramse como verdadeiros paradigmas da experiência dos cativos a bordo dos navios. Porém alguns autores trazem abordagens que apresentam novas perspectivas sobre como seria a organização, as diferentes embarcações e as dinâmicas das viagens, como

(...) por exemplo, durante os séculos em que aconteceu o tráfico marítimo de escravos africanos, uma gama enorme de 
embarcações, de diferentes tipos e tamanhos, foi utilizada para esta função; algumas construídas objetivando esse comércio e outras - na maioria das vezes - já velhas, adaptadas para esse tipo de transporte. Logo, a referência consagrada dos Negros no porão nem sempre condizia com a organização esquemática de um navio mercantil que transportava carga humana. Tudo era possível em termos de acomodação de acordo com o tipo da embarcação, mas, grosso modo, segundo Boudriot (1984), a divisão a bordo se dava em três níveis: 1 - o porão, para o armazenamento da água e dos víveres; 2 - a falsa coberta, para a carga humana (os escravos negros africanos); e 3 - a coberta, para a tripulação.

(RAMBELLI, 2006, p.62)

Mesmo que os relatos apresentem diferenças entre si no que tange o local onde os cativos eram transportados ou as formas de disciplinar os corpos no interior das embarcações, um ponto une todas essas narrativas: a crueldade. Esse aspecto inclusive manifestava-se nos diversos riscos aos quais as centenas de vidas aprisionadas estavam expostas ao longo das jornadas oceânicas.

O primeiro risco que os cativos encontravam em alto-mar era o ataque de piratas e corsários, que tinham como objetivo a interceptação das embarcações que os transportavam. O roubo dos negreiros significava diretamente expor a vida dos prisioneiros aos embates violentos que caracterizavam esses ataques,

Os escravos comprados em Moçambique, por exemplo,
estavam constantemente sob pressão de corsários franceses,
que costumavam enviar para as ilhas Maurício os cativos
interceptados. Assim, em 1796, o Nossa Senhora do Rosário e
Santo Antônio foi apresado por um corsário francês. Quando se
dirigia às ilhas francesas do Índico, seus marinheiros negros,
temerosos de serem escravizados, se revoltaram, tomaram o
comando do navio corsário e o levaram para Moçambique,
onde terminaram por receber 32 mil cruzados pelo botim. Em
outro episódio, a escuna Feiticeira, atuando no norte de
Angola, em 1825, foi 'tomada com o seu carregamento pelo
gentio de Sono, depois de possível resistência feita pelo mestre
e campanha, que ficaram maltratados e feridos, sofrendo
abordagem'.
(FLORENTINO, 1997, p.141)

Somado ao perigo de ser raptado (mais uma vez) por piratas em alto-mar, os cativos sofriam constantemente com o risco de naufrágios. Fossem por causas naturais, erros de cálculo ou de comando, o número de embarcações que ia a pique parece ter sido considerável, como mostram os números a seguir, 


\begin{abstract}
Sabe-se que dos 43 navios que transportavam escravos para a Companhia do Grão-Pará e Maranhão durante a segunda metade do século XVIII nada menos que catorze (32\%) naufragaram. Já o negreiro Athaneo, proveniente de Cabinda, aportou no Rio durante o Natal de 1812 trazendo entre os seus homens o piloto, o cirurgião, o contramestre e oito marujos do também negreiro Rainha Nantes, que naufragara perto da costa brasileira. Dos escravos por ele transportados, nunca mais se soube. Sorte distinta teve o bergantim Lisboa, proveniente de Ambriz, que fora a pique também durante o Natal, só que do ano de 1824. Estando a 140 léguas de Cabo Frio, ele teme 25 de seus tripulantes e 138 escravos salvos pelo também negreiro Vigilante, que aportou no Rio no primeiro dia de 1825.

(FLORENTINO, 1997, p.144)
\end{abstract}

Mesmo que não fossem roubados ou morressem em algum acidente que levasse o barco a naufragar, as vidas dos cativos corriam grandes riscos inerentes à própria travessia e ao tratamento desumano que recebiam durante a viagem, como já foi apontado. A esses maus tratos podemos somar a escassez de água e comida, a superlotação e, principalmente, o medo como fatores que atingiam diretamente a resistência 'física, moral e espiritual de contingentes formados muitas vezes por fatigados prisioneiros de guerra' (Florentino, 1997, p.145).

O alto nível de insalubridade dos navios era também um ambiente propício para a proliferação de diversas doenças, tornando as naus verdadeiras 'vias de duplo sentido, levando e trazendo da África enfermidades típicas da América e Europa, e vice-versa' (Florentino, 1997, p.146). Sendo as embarcações um local que não proporcionava condições de sobrevivência adequadas, presume-se que o tempo de duração das viagens fosse determinante para a garantia do maior número possível de cativos vivos. Por sua vez, o tempo de duração da travessia estava diretamente ligado à distância entre os portos que estavam na rota dos traficantes. Como nos mostram os números,

\footnotetext{
Em todo o período [1795 - 1830] perdiam-se quase três vezes mais escravos entre os cativos embarcados no Índico do que na área congo-angolana, fato perfeitamente explicável pela duração da travessia: enquanto os negreiros provenientes desta última região levavam de 33 a 40 dias no mar até o Rio de Janeiro, os daquela podiam navegar até durante 76 dias. (FLORENTINO, 1997, p.146)
}

Porém, mais para o fim do período apontado, os casos de mortes a bordo diminuíram tanto na área moçambicana como na congo-angolana, 
Assim, entre as naus provenientes desta última, os índices baixaram de 89 por mil entre 1795 e 1811 , para 55 por mil na década de 1820. Em termos gerais, com exceção de Cabinda (cuja taxa permaneceu praticamente inalterada), os dois outros principais portos abastecedores da região - Luanda e Benguela - acompanharam a tendência global. Com relação aos cativos provenientes do Índico, suas taxas de mortalidade baixaram de 234 por mil entre 1795 e 1811 para 132 por mil na década de 1820. O principal porto de embarque da região, a ilha de Moçambique, foi o grande responsável por tal fenômeno.

(FLORENTINO, 1997, p.147)

É possível que esse decréscimo esteja relacionado com mudanças no 'padrão tecnológico dos barcos da época'. A utilização de embarcações menores, que eram também mais velozes, encurtava 0 tempo das viagens, o que diminui a taxa de mortalidade. Essas naus menores, por sua vez, eram geralmente comandadas por traficantes não especializados que buscavam lucrar com o grande aumento da demanda depois da abertura dos portos' (Florentino, 1997, p.147). Porém, mesmo com medidas que diminuíam a mortalidade no interior das embarcações, os números de cativos que perdiam a vida na travessia ainda eram alarmantes.

Seria impossível apreender na totalidade todas as etapas por quais os cativos passavam antes da sua chegada ao Rio de Janeiro. O que tentamos fazer aqui foi um panorama que, mesmo sendo breve, torna evidente como a violência era um aspecto fundante, bem como a morte física e simbólica dos cativos era um elemento inerente a todo esse processo (Florentino, 1997, p.102).

A desumanização do cativo era o principal elemento que demarcava as regras nas relações de poder no tráfico negreiro e que está diretamente conectada com o que identificamos no capítulo anterior. A cidade como o mundo compartimentado entre o espaço do soberano e do escravizado era parte de um sistema de violência que já era operado desde a captura, ainda em solo africano. A dinâmica do comércio escravista caracterizava-se como a sobreposição de diversos mecanismos de precarização da vida do africano, a própria carne do mundo (Césaire, 2012) que, após ser arrancada a ferro das entranhas da 
sua terra, seria arrastada para um outro mundo, onde continuaria a verter sangue em seu novo cativeiro.

Caso tivesse a sorte de sobreviver a viagem, e se o seu destino fosse a cidade do Rio de Janeiro, entre 1774 e 1830, os homens, mulheres e crianças africanas provavelmente continuavam sua trajetória de sobrevivência no mercado do Valongo, onde eram preparados e expostos à venda pública - assumindo a forma final de 'capital-dinheiro' (Florentino, 1997, p.155) - negociados incansavelmente nos vários barracões espalhados freguesia de Santa Rita, por onde também iremos adentrar nas próximas páginas.

\subsection{A materialização do erro}

A floresta tropical acolhia na sombra das suas montanhas a cidade de São Sebastião do Rio de Janeiro, com as suas construções caiadas de branco e de telhado vermelho em contraste com a vegetação que Ihe servia de cenário. Essa era a visão agradável narrada por alguns dos viajantes que chegavam em seus navios aproximando-se do atracadouro na área portuária, que localizava-se nas freguesias da Candelária e Sacramento. Dentro do paraíso verdejante, a noroeste da região central, alguns desses estrangeiros descreveram também, com belas imagens, a vila de pescadores que estava encravada entre os morros do Livramento e da Conceição, na freguesia de Santa Rita.

É possível encontrar relatos de uma adorável aldeia pequena, com várias casas fazendo frente para o mar, onde alguns barcos ficavam atracados na praia do Valongo e do Valonguinho. Os topos dos morros estavam coroados com pequenas igrejas, que abençoavam esse conjunto, dando o efeito de uma agradável cidade costeira na província do Rio. Essa é a imagem que temos, por exemplo, na obra de Thomas Ender (Figura 2), que retratou em 1818, esse cenário confortável, em que '(...) a única distração sutil são as janelas cobertas de tijolos dos depósitos de escravos' como apontado pela historiadora Mary Karasch (2000). 


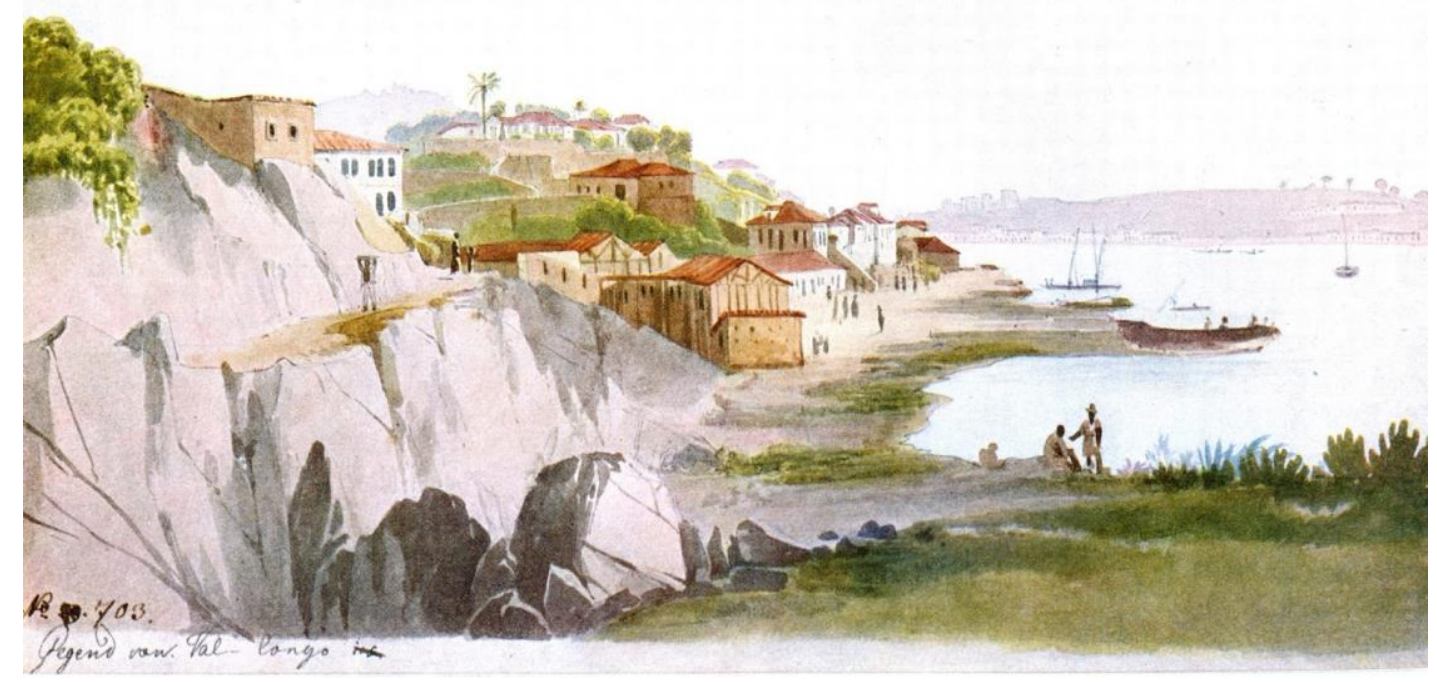

Figura 2. Valongo - Thomas Ender (1818)

Fonte: Domínio Público

Tudo parece estar dentro da normalidade na descrição da aldeia bucólica e convidativa de casas, barcos e morros, não fosse o pequeno desvio provocado pelas janelas vedadas com tijolos. Esse ruído em meio a paisagem pacata é o que desperta a atenção e alimenta a inquietação que motiva a presente pesquisa. $O$ que encontramos na imagem acima é a indicação de que existiam peculiaridades nas construções envolvidas na produção de milhares de escravizados ao longo de mais de dois séculos no Rio de Janeiro.

Ao mesmo tempo que tais espaços cumpriam etapas na agenda do comércio de escravizados, eles também faziam parte da paisagem da cidade, estavam inseridos no espaço urbano e espelhavam um modo de vida. Enquanto o senhor de escravizados vê-se refletido nas construções que formam a 'agradável cidade costeira', o cativo faz-se presente 'na janela coberta de tijolos'. O escravizado nessa cena é a deformação do espaço, a 'distração' é a barreira de tijolos, que impede a entrada de luz, podendo ser lida tanto como um índice da presença do seu corpo negro- 
africano no ordenamento espacial como também o signo da sua condição de confinamento. O escravizado era um enclausurado. Estava sepultado em vida.

A pintura de Thomas Ender é um retrato da região onde funcionou, de 1774 a 1831, o maior 'complexo comercial de negroafricanos escravizados do mundo' (Dossiê, 2017, p.25), o mercado do Valongo. Ainda que alguns viajantes tenham utilizado traços mais agradáveis para registrar sua passagem pela região, não havia como ignorar a presença de tal atividade no local, que atraía o interesse de muitos. Mesmo localizado estrategicamente fora dos limites do centro urbano do Rio de Janeiro, o Valongo possuía uma pulsante atividade que trazia para a região um caráter único ditado tanto pela sua dinâmica como pela sua materialidade.

O objetivo das páginas que seguirão é o de acompanhar como se deu a constituição do espaço físico que compunha o complexo comercial do Valongo, tendo como fio condutor os documentos oficiais (leis, cartas, declarações) que expressavam as intenções políticas, sociais e econômicas que delineara a forma e a função do mercado de escravizados. Como vimos no capítulo anterior, a cidade do Rio de Janeiro era organizada, física e socialmente, para manter as divisões entre o mundo do soberano e o do escravizado evidentes e sólidas; o espaço urbano era um ambiente altamente restrito e cheio de interdições que reproduzia as lógicas de subalternização e violência intrínsecas ao processo de escravização. Foi visto também que esta experiência de violência estava presente desde o momento do apresamento do cativo no continente africano até a sua chegada em terras cariocas. Sendo assim, o percurso que faremos a partir de agora também se engaja na compreensão de como tais aspectos estavam presentes no mercado do Valongo, estruturando e materializando a brutalidade da escravização em galpões, ruas e cemitérios.

Esses elementos que funcionavam como partes de uma máquina com o objetivo de produzir continuamente os escravizados necessários para alimentar a economia da época eram resultado de anos de aperfeiçoamento e sofisticação tanto da empresa escravista como do 
poder público, que ao se manterem em conexão direta produziram modificações espaciais que transformaram o conjunto de armazéns que comercializavam escravizados no Centro da cidade até meados do século XVIII, no maior 'complexo comercial' de cativos do mundo, quando foi desativado 1830. O primeiro momento dessa transformação foi a concentração de todo o comércio de cativos da cidade na região do Valongo. De acordo com Soares (2013),

\begin{abstract}
Em resumo podemos afirmar: o Valongo era a culminância das reformas do mercado de escravos, iniciadas na década de 1760, quando a cidade se torna capital política da América portuguesa. Dom João VI, como primeiro monarca europeu nos trópicos, realizou diversas obras na cidade, para não apenas torná-la digna de uma corte europeia, mas para ganhar o apreço das elites do país. E a escravidão era o insumo básico da economia do país da época.
\end{abstract}

(SOARES, 2013, p.8)

O mercado de escravizados do Rio de Janeiro permaneceu por muito tempo concentrado na região central da cidade, acompanhando a movimentação da zona portuária, próxima à Alfândega e o Paço Imperial, mantendo-se próximo do centro comercial e administrativo. O médico Mateus Saraiva, identificado como professor na Ordem de Cristo, cidadão do Rio, físico-mor das tropas reais, médico da Câmara e Saúde e sócio da Real Sociedade de Ciência de Londres, descreveu com detalhes onde estava localizado o negócio negreiro em 1758,

(...) na Rua Direita, da Casa dos Contos até a ladeira do mosteiro de São Bento. Nesse trecho importante da freguesia da Candelária ficavam os armazéns e as casas de comércio de escravos dos principais negociantes do ramo e de alguns que tinham em suas próprias moradias posto de venda, onde recolhiam os escravos novos.

(CAVALCANTI, 2005, p.46)

Nesse período os navios tumbeiros eram autorizados a entrar livremente para o desembarque no centro da cidade. Assim que ancoravam os navios eram submetidos a formalidades, que após realizadas permitiam que a tripulação transferisse os negros novos (nome dado aos africanos recém-chegados) para embarcações a remo menores, para que fossem levados à Alfândega. Ao chegarem, as autoridades alfandegárias procediam a contagem por sexo e faziam as devidas anotações para a cobrança dos tributos sem os quais não era permitido realizar legalmente a venda dos cativos na cidade. Cumpridas estas 
etapas iniciais, as peças eram levadas para o local onde procederia o leilão, que poderia determinar o seu destino logo após o desembarque, caso houvessem compradores suficientes. Concluídas todas as vendas, ainda na porta da Alfândega, os traficantes redirecionavam os cativos que restassem no grupo para um dos 39 armazéns onde seriam preparados para a venda, assim que recobrassem a saúde ${ }^{7}$.

O espetáculo de horrores que se apresentava a olhos nus, em pleno centro da cidade chocava a população, e mais ainda os viajantes que descreveram as visões de africanos com 'olhares indiferentes', 'tristes' e 'acabrunhados' no convés das embarcações. Já sobre o desembarque relatavam

(...) a aparência grotesca de africanos esqueléticos, cuja pele adquiria um tom cinza escamoso com o escorbuto, semivestidos com tecido de algodão colorido e gorros vermelhos. Devido aos rigores da jornada da África, chegavam quase invariavelmente magros e descarnados, com pele escrofulosa cheia de feridas, brotoejas e sarna, para não mencionar as bexigas horríveis de varíola. As crianças pequenas tinham a barriga inchada pela desnutrição e vermes. Se uma epidemia de oftálmica tivesse atacado muitos durante a viagem, os vendedores puxavam filas de escravos cegos tropeçando uns atrás dos outros até o armazém.

(KARASCH, 2000, p.74)

Esta visão degradante que muito se distanciava da imagem desejada pelas autoridade e elites locais de uma cidade civilizada e próspera, logo mobilizou parte da sociedade que levou seu descontentamento até a Câmara Municipal imbuídos por uma preocupação de saúde pública. Sendo assim,

Os vereadores Francisco Pereira, José Pacheco Vasconcelos, Miguel Cabral de Melo e Tomé de Gouveia Sá Queiroga, sob a presidência do Juiz de Fora Antonio de Matos e Silva, em 14/1/1758, convidaram 'os professores de medicina' (os médicos Antonio Ferreira de Barros, Francisco Correria Leal e Mateus Saraiva, os cirurgiões Antonio Luiz de França, Antonio Mestre e Luiz Estevão) para discutirem e deliberarem, em Acórdão, sobre o comércio de escravos novos. Tratava-se de uma questão de conceito sanitarista: o comércio de escravos novos se dando no interior de área urbana densamente construída e habitada provocaria ou seria foco de epidemias que assolavam a cidade do Rio?

\footnotetext{
7 Jaime Rodrigues, com base na pesquisa de Eulália Lobo, cita a presença de 39 armazéns credenciados para a venda de escravizados na região até 1779 . Porém, é sabido que eram inúmeros os vendedores que não estavam credenciados e nem possuíam local próprio para a manutenção de cativos estando, por isso, fora dos parâmetros legais. (Rodrigues, 2013, p.366)
} 
(CAVALCANTI, 2005, p.42)

Somada à inquietação e à perturbação que o alojamento e o comércio de tantos africanos gerava na região central da cidade, estava também uma preocupação de fundo econômico, visto que tal localização só favorecia os compradores locais, dificultando o acesso dos que vinham de partes mais distantes da cidade. Cavalcanti (2005) aponta que

\begin{abstract}
Existiam três tipos básicos de compradores de escravizados nesse período: (...) o comerciante estabelecido com armazém para revenda de escravos novos, os ricos que adquiriam os escravos mais sadios e prontos para o trabalho (consequentemente, de valor mais alto) e aqueles da raia miúda que adquiriam a preços módicos os doentes, os aleijados e os velhos, isto é, os chamados 'refugos'. Mostra também que esses compradores de refugo, no caso de comerciantes, desenvolveram uma rede de especialistas em recuperação desses escravos doentes, preparando-os para revenda a preços que compensassem os investimentos neles aplicados. Obviamente, esses atravessadores e os compradores pobres formavam um conjunto necessário e oportuno para a alimentação do ciclo do comércio negreiro.
\end{abstract}

(CAVALCANTI, 2005, p.41)

Estes compradores que vinham de longe, por sua vez, tinham alto poder aquisitivo - em sua maioria 'senhores de engenho, fazendeiros, lavradores, negociantes de médio e grosso trato (isto é atacadistas), capitalistas, revendedores de escravos para Minas Gerais e outras capitanias' - e demoravam muito pra receber a notícia da chegada do carregamento de cativos; além disso também tinham um tempo maior de deslocamento, o que fazia com que chegassem quase sempre depois da distribuição das melhores peças. Esse atraso os obrigava a adquirir os escravizados através de terceiros, que poderiam tanto ser os vendedores locais ou os atravessadores que armavam caravanas para o interior (Cavalcanti, 2005, p.42).

Entre essa guerra de interesses comerciais e políticos definiu-se em 28 de janeiro de 1758 que o comércio de negros novos, por ocorrer na região mais populosa e densa da cidade afetava a Saúde Pública, seria necessário que fosse deslocado para fora da área urbana. Ficou também proibida a utilização do chafariz da Carioca para a costumeira lavagem dos africanos recém-chegados, por riscos de contaminação e distúrbios da ordem pública. Como forma de fixação de tais definições foi aprovado um Edital com as seguintes normativas: 
a) A retirada dos pontos comerciais na área central da cidade e sua instalação na periferia ou, como era classificada na época, arrabalde ou subúrbio;

b) Proibição às pessoas de 'qualquer estado ou condição que seja, ter dentro da cidade, assim em casa, como nas ruas, rocios e praças dela, magotes de negros novos', definindo como 'magotes' a quantia de cinco negros novos juntos, mesmo que fossem eles de diferentes donos;

c) Exigência aos donos de escravos novos que iriam enviá-los ou vendê-los em Minas Gerais de, no tempo de 24 horas, após a compra, 'serem manifestos' ao Senado da Câmara e em oito dias serem obrigatoriamente retirados "para fora da cidade';

d) Proibição de serem levados os escravos novos para o chafariz da Carioca.

(CAVALCANTI, 2005, p.44)

O subúrbio citado pelo documento referia-se a região do Valongo, que era apontado como local mais indicado,

(...) tanto do ponto de vista do acesso quanto da aeração e possibilidade de lavagem com a água do mar dos negros recém-chegados, era a orla marítima do Valongo, Saúde e Gamboa ou, no interior, a zona do mangue de São Diogo, cujo acesso se fazia pelo estreito braço de mar que penetrava até a altura da atual Praça Onze, na avenida Presidente Vargas. A preferência foi pela região do Valongo por já ter acessos por mar e por terra através do Caminho do Valongo (atual rua Carmerino) ligando-a à área central da cidade.

(CAVALCANTI, 2005, p.43)

O que ocorreu após a definição da Câmara foi o aviltamento dos comerciantes locais (precisamente 39 deles) que contestaram veementemente $\mathrm{o}$ argumento sanitarista, entrando com um recurso baseado na afirmação de que a prática estava em exercício na região há muito tempo, sem originar quaisquer transtornos de saúde. Além de negarem os danos à saúde pública também apontavam que os escravizados não causavam perturbação, visto que ficavam muito 'quietos e assentados' na porta das casas de vendas, sendo que nem se levantam sem 'que primeiro os mandem'. Outro ponto levantado nesta contestação dos comerciantes é o 'gravíssimo prejuízo em serem extraídos os mesmos escravos para fora da cidade, pois não podem largar suas casas'. De acordo com o que expressam na carta endereçada às autoridades, a decisão da Câmara desarticularia os seus negócios que também estavam ligados a outros produtos, além dos cativos ${ }^{8}$.

\footnotetext{
${ }^{8}$ Para ler carta completa: Honorato, 2008, p.70.
} 
Mesmo não sendo acatada por todos, alguns comerciantes seguiram as ordens do edital e transferiram seus negócios para 0 Valongo. Contudo, em 29 de janeiro de 1766 precisou ser baixado um novo edital reforçando as proibições anteriores e acrescentando a restrição aos negros novos que vinham da Bahia, Pernambuco e Maranhão.

Ainda no mesmo ano, parte da elite tornou a defender a sua preocupação com relação à degradação moral da presença dos comerciantes que insistiam em permanecer na zona central da cidade, redigindo um abaixo-assinado no dia 26 de junho em que,

(...) argumentaram esses ilustres consumidores de escravos, que numa cidade importante do porte do Rio de Janeiro não era admissível haver o espetáculo repugnante que ocorria todas as vezes que chegava um navio com escravos novos: negros e negras seminus, banhos no mar em frente à praia do Peixe, no cais de Brás de Pina e Mineiro e na circunvizinhança da Alfândega e, sobretudo, fazerem suas necessidades fisiológicas à vista de todos.

(CAVALCANTI, 2005, p.45)

A continuação desta contenda dá-se no Tribunal da Relação, onde os comerciantes da região central da cidade conseguem o apoio da maioria dos desembargadores, que votaram favoráveis à sua questão. Manolo Florentino indica uma curiosidade nesta etapa do processo,

\begin{abstract}
Isso [decisão favorável dos desembargadores] graças aos depoimentos de médicos e cirurgiões que declararam não haver relação do comércio de escravos novos naquela área da cidade com as epidemias. Curiosamente, foram depoentes favoráveis aos comerciantes de escravos muitos dos profissionais presentes na reunião da Câmara de Vereadores de 14/1/1758 quando se concordou que o comércio na área central era prejudicial à saúde pública: os médicos Antônio Ferreira de Barros, Francisco Correa Leal e os cirurgiões Antonio Luiz de França, Antonio Mestre, Francisco Gomes da Costa Brito e João da Silva Passos Cabral. Em seus depoimentos, dados em março de 1768, confessam que trabalhavam para os negociantes de escravos novos, muitos há 25, 30 anos, e por essa razão tinham experiência e vivência do problema.
\end{abstract}

(CAVALCANTI, 2005, p. 45)

Um dos depoentes, o já citado médico Mateus Saraiva, atesta que nos seus 43 anos de vivência na área nunca havia presenciado qualquer enfermidade causada pelo comércio e cativos. Esse posicionamento mostra-se completamente contrário ao tomado pelas mesmas autoridades 
em 1758, expondo ainda mais as lacunas e as relações de interesses que tangenciaram essas decisões sucessivas.

Foi apenas em 1774, que o então vice-rei marquês de Lavradio, com a autoridade de presidente do Tribunal da Relação, pôs um fim nessa discussão através da decisão documentada no dia 12 de abril do referido ano, como podemos ver na transcrição trazida por Cavalcanti (2005) a seguir:

Sendo-me presente os gravíssimos danos, que se tem seguido aos moradores desta cidade de se conservarem efetivamente, dentro da mesma, imensos negros novos que vêm dos portos da Guiné e Costa da África, infestados de gravíssimas enfermidades, assim adquiridas na viagem, como das que the sobrevêm depois de saltarem em terra, pela falta do cuidado e comodidade, com que deverão ser tratados, dos quais se acham sempre cheias a maior parte das ruas, e casas dos comerciantes, que os costumam vender, sem jamais se extinguirem os mesmos e numerosos lotes, que há deles para aquelas partes, donde se acham, para serem vendidos, com a introdução de novo com os que estão chegando daqueles mesmo portos e costa, de que tem resultado contagiosas queixas epidêmicas, de que de anos a esta parte se acha infestado todo esse país, como a experiência o tem mostrado, na falta de mais de seis mil pessoas que dentro de muito pouco tempo têm morrido nesta cidade e na vila de Campos acometidos de bexigas, depois que para a mesma vila se começou a levar a grande multidão dos referidos escravos, que nela se têm introduzido; e sendo esta lamentável ruína digna do mais pronto e eficaz remédio, a fim de que cessando os estragos que têm assolado e destruído a todo este continente, se possa conservar a saúde dos povos tão recomendada por $\mathrm{E}$ Rei Meu Senhor, o que já em outro tempo foi ponderado pela Câmara dessa Cidade, que justamente persuadida pelos pareceres dos professores, de que as contagiosas moléstias que se experimentava eram causadas da infecção dos negros novos, que se achavam a vender pelas ruas e praças da cidade, os mandou logo retirar, para fora dela, o que não teve efeito, por passarem aqueles mesmo segundas certidões em contrárias às primeiras, talvez depois de subornados pelos comerciantes vendedores dos mesmo escravos as quais se acham juntas aos Autos do Litígio, que pendeu sobre este ponto, em que finalmente se julgou a favor dos mesmos comerciantes sem embargo das funestas consequências, que daqui se seguiram, a que os Magistrados deixaram de atender sem haver razão em que se fundarem para ao bem comum de verem prevalecer os falsos interesses particulares, querendo por aplicar o remédio as gravíssimas queixas, que têm infeccionado todo este país com imensos danos dos seus moradores, que vendo-se assolados, reduzidos a última miséria e oprimidos das ruínas de tantos estragos, bradam, gemem e suspiram aflitos e desconsolados pelo alívio e socorro de tantos males, sem até o presente terem sido atendidos os seus termos gemidos e justos clamores. Me pareceu dizer a vós mercês haja de dar aquelas providências que entenderem necessárias, a fim de que não sejam conservados nessa cidade os negros novos, que vêm dos 
portos da Guiné e Costa da África, ordenando, que tanto os que se acharem nela, como os que vieram chegando de novo daqueles portos, de bordo das mesmas embarcações que os conduzirem, depois de dada a visita da Saúde, sem saltarem a terra, sejam imediatamente levados ao sítio do Valongo, onde se conservarão, desde a Pedra da Prainha até a Gamboa e lá se lhes dará saída e se curarão os doentes e enterrarão os mortos, sem poderem jamais saírem daquele lugar para esta cidade, por mais justificados motivos que hajam e nem ainda depois de mortos, para se enterrarem nos cemitérios da cidade e no mesmo lugar os poderão ir ver e ajustar as pessoas, que os quiserem comprar e os que forem para passar para Minas, ou outras diferentes capitanias, se conservarão ainda depois de comprados naquele mesmo sítio até a hora da partida dos seus donos, que só nessa ocasião os irão receber para dali os transportarem em direitura, para as partes dos seus destinos; e, só aqueles, que forem comprados para algumas fazendas da terra firme desta cidade, ou para o serviço dos moradores dela, poderão ser trazidos, para o Campo de São Domingos donde se conservarão da igreja de Santana para baixo, para daquele lugar serem conduzidos, para as referidas fazendas, todos os que forem comprados para elas, todas as vezes que seus donos os quiserem levar, ou mandarem buscar e, da mesma forma, serem trazidos, para esta cidade os que forem para o serviço dos moradores dela e não será nunca permitido exceder o número de cinco a cada um dos moradores, que os forem buscar e só sim deste mesmo número para baixo e ainda a estes se não consentirá a aqueles mesmos moradores tê-los pelas ruas; e só sim dentro das suas casas, o que tudo farão vós mercês executar, mandando que assim se haja de observar daqui em diante, enquanto El Rei Meu Senhor não mandar o contrário. Deus guarde a vós mercê. Rio de Janeiro, 12 de abril de 1774.

(CAVALCANTI, 2005, p.48)

Em suas palavras, o marquês de Lavradio não só reforça as decisões tomadas pelo edital de 1758 como também apresenta novas definições para o Valongo. Muitas são as leituras possíveis a partir do texto acima e algumas delas serão realizadas posteriormente. Por ora, é importante identificar a vocação segregacionista com que foi tomada a decisão de restringir o mercado de escravizados para a região do Valongo.

O espaço geograficamente delimitado que ia '(...) desde a Pedra da Prainha até a Gamboa' era o único local em que o escravizado recémchegado poderia ocupar enquanto seu destino não fosse definido em alguma transação comercial. Nem a sua morte significaria o rompimento dessa barreira, visto que as ordens são expressas ao dizer que 'sem poderem jamais saírem daquele lugar' o seu enterramento deveria ser feito dentro dos limites espaciais definidos pelo edital. Essa restrição 
espacial destinada ao comércio de cativos, corrobora com a ideia apresentada até o momento: o Rio de Janeiro era um mundo dividido, um espaço de interdições e fronteiras, que mantinham soberano e escravizado em uma relação totalmente assimétrica.

As palavras do marquês de Lavradio também são claras quanto às condições de existência concedidas ao negro-africano no espaço colonial carioca, restando-Ihe ser 'conversado', 'tratado', 'vendido', 'morto', 'levado', 'trazido', 'mantido', 'contaminado', 'retirado', 'conduzido', 'enterrado'. Porém, seu texto afirma que eram os moradores livres, e brancos, em sua esmagadora maioria, que estavam 'assolados, reduzidos a última miséria e oprimidos das ruínas de tantos estragos'. Eram os seus 'brados e gemidos', os 'suspiros aflitos e desconsolados de socorro', e seus 'justos clamores' que foram atendidos com a retirada do comércio de escravizados da região central da cidade.

Não que o negro-africano escravizado não gritasse. Suas cordas vocais vibravam mas sua boca estava bloqueada, amordaçada pela dominação colonial como nos diz, a artista e pensadora portuguesa, Grada Kilomba (2010). E era a partir dessa mudez imposta que a voz do colonizador virava o único clamor audível, produzindo uma narrativa inversa, típica das práticas coloniais em que a presença do negro-africano transformava-se em um perigo para o colonizador que ignorava perversamente a violência com que aprisionava o escravizado. Esse processo é chamado por Kilomba (2010) de recusa e era utilizado,

(...) para manter e legitimar estruturas violentas de exclusão racial: 'Eles/elas querem tomar o que é Nosso, por isso têm de ser excluídos(as).' A informação original e elementar 'Estamos tomando o que é Deles (as)' - é negada e projetada sobre o(a) 'Outro(a)' - 'Eles/elas estão tomando o que é Nosso' - o sujeito negro torna-se então aquilo a que o sujeito branco não quer ser relacionado. Enquanto o sujeito negro se transforma em inimigo intrusivo, o branco torna-se a vítima compassiva, ou seja, o opressor torna-se oprimido e o oprimido, o tirano.

(KILOMBA, 2010, p.174)

$\mathrm{Na}$ leitura do texto do marquês de Lavradio esse fenômeno de 'recusa' e de inversão da narrativa fica nítido, expondo as intenções de manutenção da condição de 'morte em vida' com que o negro-africano era relegado no ambiente colonial. Conforme observa Mbembe (2016, p.132), 
"A vida de um escravo, em muitos aspectos, é uma forma de morte em vida."

A partir das ordens do vice-rei, a situação do cativo estava bem definida: só lhe era permitido tocar o solo da soberania quando dela se tornasse propriedade. O que ainda assim não significava a dissolução das suas interdições, pelo contrário, só reproduzia um padrão de violência reiterado e atualizado a todo momento em seu corpo e na sua subjetividade.

Seguindo ainda as palavras deste documento, fundamental para a existência do mercado do Valongo, é possível perceber as primeiras diretrizes da conformação do ordenamento espacial do 'complexo comercial', como um conjunto de equipamentos urbanos interligados ${ }^{9}$. Esta intenção torna-se evidente através da proibição da retirada dos corpos dos negros novos falecidos da região, impedindo os enterramentos nos tradicionais cemitérios da cidade, o que implicava diretamente na construção de um espaço de enterramentos dentro da região do mercado. Deste modo, em um só documento, temos a delimitação geográfica do mercado de escravos e também a criação de um equipamento urbano que iria compor o complexo comercial até a sua desativação: o Cemitério dos Pretos Novos.

É importante também ressaltar o fato de que a transferência definitiva do mercado de escravizados para o Valongo, bem como sua transformação em um 'complexo comercial', coincidem com o já citado período de especialização de alguns setores da cidade, dando uma nova função para a então pouco explorada freguesia de Santa Rita e ao mesmo tempo liberando a Rua Direita, que nesta época já era a principal artéria da cidade, de uma atividade que não condizia com as intenções do poder público e das elites cariocas (Lamarão in Soares, 2013, p.16). Cabe lembrar que a freguesia de Santa Rita, até então era uma pequena vila de pescadores, isolada do perímetro urbano conforme mostra Claudio Honorato (2008),

\footnotetext{
${ }^{9}$ De acordo com NBR9284/86 - Equipamento Urbano entende-se como "todos os bens públicos e privados, de utilidade pública, destinados à prestação de serviços necessários ao funcionamento da cidade, implantados mediante autorização do poder público, em espaços públicos e privados."
} 


\begin{abstract}
A área em questão compreendia uma estreita faixa de terra espremida entre as águas da Baía de Guanabara e uma compacta parede montanhosa que praticamente isolava esta faixa do litoral da urbe. O litoral, bastante recortado, caracterizava-se por uma sucessão de enseadas, destacandose os sacos do Valongo, da Gamboa e do Alferes. No final desse trecho da orla marítima, o mar penetrava profundamente no continente, formando o saco de São Diogo, com a praia Formosa, dominado por manguezais que se estendiam até o atual Campo de Santana. Próximas à costa, na altura da inflexão do Saco do Alferes para a praia Formosa, encontravam-se as ilhas das Moças (ou dos Cães) e dos Melões (ou João Damasceno).

(HONORATO, 2008, p.26)
\end{abstract}

A decisão do marquês de Lavradio impulsionava a ocupação da região, que passava sistematicamente a integrar-se ao resto da cidade. Já no início do século XVIII havia uma concentração de construções na estreita faixa litorânea vinculadas com as atividades dos pequenos ancoradouros, que tiravam proveito do caráter mais resguardado da área. Nesse mesmo período é registrado o surgimento de duas vias: a ladeira do Livramento que saía do litoral cortando a encosta do morro de mesmo nome e terminando na capela de Nossa Senhora do Livramento e o caminho do Valongo, que estava localizado do outro lado da formação rochosa, marcando o limite entre os morros do Livramento e da Conceição. Este segundo caminho, após 1750, foi ampliado através do secamente dos brejos praianos e ampliação das vias existentes que ganharam novo calçamento; assim como também foram realizadas obras de esgoto na região. Outra parte da freguesia de Santa Rita, até então desabitada, a receber uma função importante neste novo momento é o caminho da Gamboa que conformava uma pequena ligação entre o Valongo e o saco da Gamboa, e que a partir de então receberia o já citado Cemitério dos Pretos Novos, passando então a chamar-se Rua do Cemitério (Honorato, 2007, p.35).

Com o passar dos anos a região presenciou um aumento demográfico causado pela crescente relevância que o mercado de escravizados ganhava, uma vez que o Brasil se consolidava como o grande polo gerador de demanda de escravizados africanos, o tráfico e o comércio negreiro foram as forças propulsoras que motivaram as 
mudanças que ocorreriam na freguesia de Santa Rita, conforme constata Carlos Eugênio:

$\mathrm{Na}$ aurora do século XIX o Brasil era o grande receptador de escravos africanos do mundo Atlântico. Mas as mudanças da conjuntura mundial obrigaram o estado bragantino no exílio a interferir cada vez mais neste comércio. Em 1810 a coroa publicou nova legislação criando mais um tributo para 0 comércio de africanos no Império. Este tributo, aplicado em todo território da América portuguesa, foi a base financeira para as obras que completariam o complexo do Valongo.

(SOARES, 2013, p.17)

A legislação citada na passagem acima trata-se de um Alvará de Regimento datado de 22 de janeiro de 1810, que tinha como principal preocupação, segundo as palavras do Príncipe Regente,

(...) a conservação da saúde publica e o zelar-se que ele não se estrague por contagio communicado por embarcações, passageiros e mercadorias, que entrem neste porto e nos demais deste Estado, contaminados de peste, e de molestias contagiosas, e por meio de mantimentos e viveres tocados de podridão, ou já corrompidos (...)

(Alvará de 22 de janeiro de 1810 - Coleção das Leis do Brasil de 1810 - Rio de Janeiro: Imprensa)

Para que fossem garantidos os cuidados e vigilâncias necessários, neste Regulamento foi divulgada a criação da função de Provedor Mor da Saúde da Corte e do Estado do Brazil, cargo ocupado por Manoel Vieira da Silva. Posto que os cativos eram tratados como outras mercadorias de consumo que desembarcavam no Rio de Janeiro, o presente documento dedica vários dos seus trinta e dois parágrafos a outras questões que não estão diretamente ligadas ao comércio negreiro. Porém, logo no primeiro parágrafo já somos apresentados a um dos principais frutos deste Regulamento, como é possível observar a seguir,

$\S \mathrm{I}$. Estando proximamente abertos pelas minhas reaes ordens os portos deste Estado ao commercio das Nações Estrangeiras, que estão em paz com a Portugueza; para que se não communiquem enfermidades contagiosas das suas embarcações, equipamentos e mercadorias, deverá construirse um Lazareto, onde façam quarentena, quando houver suspeita, ou certeza de infecção. E enquanto se não edifica e estabelece com a regularidade a fórma que convem, far-se-ha a quarentena no sitio da Boaviagem, onde provisoriamente se farão as acommodações precisas, e ahi deverão ancorar as embarcações impedidas pelos Officiaes da Saude.

(Alvará de 22 de janeiro de 1810 - Coleção das Leis do Brasil de 1810 - Rio de Janeiro: Imprensa) 
O que temos inicialmente é a demarcação de mais um equipamento urbano que se fazia necessário para a otimização das ações do comércio escravista no Valongo, a edificação de um Lazareto para a quarentena das mercadorias identificadas como infectadas ou mesmo suspeitas, pelos Oficiais da Saúde. Conforme consta no presente documento, o Lazareto seria mantido e administrado pelo cofre da Saúde com fundos recolhidos pela Alfândega através do acréscimo de valores específicos nas taxas recolhidas pelos navios que fossem direcionados para quarentena.

Seguindo adiante no texto do Regulamento encontramos outros dois parágrafos importantes para a compreensão desta nova função que instalava-se no Valongo. São eles:

$\S$ V. Os navios, que trouxerem carregação de escravos, esperarão no ancoradouro do Paço, ou no da Boaviagem, até que se faça a visita da Saude pelo Guarda-Mór e mais Officiaes; e feita ella, irão ancorar, e ter quarentena no ancoradouro da llha de Jesus.

$\S$ VI. No acto da visita se determinarão os dias que cada um destes navios deve ter de quarentena, conforme as molestias que trouxer, mortandade que tenha havido, e mais circumstancias que ocorrerem; porém nunca terão de quarentena menos de oito dias, em que os negros estejam desembarcados, e em terra na referida llha para ahi serem tratados, fazendo-os lavar, vestir de roupas novas, e sustentar de alimentos frescos; depois do que se Ihes dará o bilhete de Saude e poderão entrar na Cidade para se exporem à venda no sitio estabelecido do Valongo.

(Alvará de 22 de janeiro de 1810 - Coleção das Leis do Brasil de 1810 - Rio de Janeiro: Imprensa)

Como nos diz o §V os navios deveriam realizar duas ancoragens, uma para a inspeção sanitária e outra para a quarentena, sendo que qualquer navio identificado como infectado ficaria no mínimo oito dias de quarentena antes de poder distribuir sua carga no Valongo, conforme previsto no $\S$ VI. O Regulamento estende-se por mais vinte parágrafos definindo diretrizes para demais produtos e áreas específicas para o seu tratamento, até citar novamente o Lazareto,

$\S$ XXVII. Em cada uma das referidas terras [Cidade da Bahia, Pernambuco e demais portos onde se faz maior commercio] os Governadores, ouvindo ao Ouvidor da Comarca e ao GuardaMor respectivo, destinarão o sitio e logar proporcionado para servir de Lazareto para os negros, e mandarão fazer as accommodações precisas para o seu desembarque e agasalho em terra, onde se deverá praticar o que se ordena neste Regimento, antes de entrarem nas povoações, pagando-se as 
despezas pelo cofre das contribuições que ficam declaradas, cujas sommas se poderão adiantar pela minha Real Fazenda. $\mathrm{E}$ os Guardas-Mores assistirão no sitio conveniente que pelos sobreditos lhes for determinado, assim como os mais Officiaes da Saude, para com promptidão cumprirem com as suas obrigações; e executarão o que neste Regimento se Ihes determina, dando as partes, e remettendo ex-officio os processos ao Magistrado que servir de Provedor-Mor.

(Alvará de 22 de janeiro de 1810 - Coleção das Leis do Brasil de 1810 - Rio de Janeiro: Imprensa)

Além de definir os cargos de Delegado e Oficiais-Mores da Saúde para as cidades da Bahia, Pernambuco e demais portos, o Regulamento de 1810 também torna evidente a intenção da Coroa de replicar o padrão de organização espacial que estava sendo implantado no Valongo para outras partes do país. Porém, mesmo estando de acordo com as intenções das autoridades e com as preocupações com a saúde pública que tanto assolavam a população, a proposta do Lazareto, bem como outras diretrizes deste Regulamento não foram bem aceitas pelos comerciantes e traficantes cariocas.

O principal alvo das suas reclamações era 0 excesso de ancoragens, visto que julgavam desnecessária a primeira parada no Paço ou na Boa Viagem, sugerindo que fossem direto para a llha de Bom Jesus, pois afirmavam que a espera na primeira ancoragem deixava as embarcações expostas aos inconvenientes do tempo.

Outro ponto levantado pelos traficantes era a alegação de que a Provedoria da Saúde, no período de quarentena, acabava por misturar os cativos sadios com os infectados, tornando maiores os riscos de contágio. A solução apontada por eles era a liberação da obrigatoriedade da parada no Lazareto, sendo permitida a realização da quarentena dos cativos infectados no interior dos próprios navios - ou em casas particulares e a liberação dos sadios para o comércio no Valongo. Os traficantes julgavam excessivas as exigências de quarentena, como também não estavam dispostos a pagar ainda mais tributos ${ }^{10}$.

\footnotetext{
${ }^{10}$ Claudio Honorato acompanha todos os desdobramentos desta revolta dos traficantes, bem como os posicionamentos do Provedor-Mor de Saúde, que refutavam cada argumento levantado nas reivindicações em 'A quarentena na Ilha do Bom Jesus e a criação do Lazareto da Saúde' in. Honorato (2008).
} 
Após muitas discussões entre os comerciantes e o Provedor-Mor de Saúde, os traficantes não conseguiram ter toda as suas reivindicações atendidas, porém chegaram a um acordo sobre o fato de que a llha de Bom Jesus era imprópria para a função do Lazareto, sendo retificados os $\S$ V e § VI do Regulamento anterior, conforme texto abaixo:

Constatando das averiguações, a que procedeo o Provedor-
Mór da Saude, que a llha de Bom Jesus era mui distante desta
cidade, e com passagem de Mar, e por estas razões menos
própria para a quarentena, que devem fazer os Escravos
novos; e Attendendo, que não he esta rigorosamente
necessária para os que chegão sãos, e sem suspeita de
epidemia: Determino, em declaração dos $\S$ $\S$ V e VI. do
Regimento, que o lugar da quarentena seja adiante do Sitio da
Saude, designado pelo Provedor Mor; e que os que chegarem
sãos, sendo lavados, envoltos em roupas novas, se entregue
logo a seus donos para poderem vender nos seus armazéns,
ficando em quarentena os doentes, ou empestados pelo tempo,
que for julgado necessário.
(ANRJ - Série Saúde IS42 - Alvará de 28 de julho de 1810 in
HONORATO, 2008, p.105.) Isto posto, ficou delimitada a edificação do Lazareto atrás do Monte de Nossa Senhora da Saúde. Todavia, o Cofre da Saúde não possuía a quantia necessária para realizar a construção, nem a administração deste equipamento urbano, ficando então decidido que as despesas do Lazareto seriam custeadas pelos próprios negociantes, sendo que apenas três se responsabilizaram a cumprir a empreitada: João Gomes Valle, José Luiz Alvas e João Álvares de Souza Guimarães e Companhia. Conforme indica Claudio Honorato, as despesas de construção da edificação excederam cem mil cruzados, restituída posteriormente aos comerciantes,

(...) pelo pagamento de 400 réis por cada escravo recolhido, conforme ordenou S.A. R. (aviso de 6 de maio de 1810). O aviso determinava que todo o proprietário ou consignatórios das embarcações cujas arqueações entrassem no Lazareto as cumprisse fielmente, mas o que ocorreu foi justamente 0 contrário. Os negociantes recusaram-se a pagar a devida quantia por acharem-na abusiva, desobedecendo assim a Ordem Régia, e encaminharam um abaixo-assinado ao Príncipe Regente, pedindo a revogação do mesmo. (HONORATO, 2008, p.106)

O Lazareto passava então a ser um equipamento público urbano administrado de forma privada que, mesmo com as legislações e normativas impostas pela Provedoria da Saúde, foi acompanhado durante todo o seu período de funcionamento pela rebeldia dos negociantes que 
insistentemente burlavam as leis de vigilância, tornando prática comum o aluguel de casas particulares no entorno do Lazareto para que fossem feitos os tratamentos dos cativos em quarentena.

As questões que determinavam a instalação do Lazareto estavam presentes também em outra legislação muito importante para o período, a Lei de Arqueamento de 1813. Nela o Príncipe Regente determinava, novos parâmetros para a condução dos cativos que vinham dos portos da África para o Brasil. Apresentando preocupações com relação ao 'tratamento duro e inhumano' recebido pelos africanos, e ressaltando a 'barbaridade e sordida avareza de muitos dos Mestres das embarcações que os conduzem' em navios sobrecarregados 'faltando-Ihes com alimentos necessários para a subsistencia delles, não só na quantidade, mas até na qualidade, 11 .

Imbuído de todos os seus 'constantes e naturaes sentimentos de humanidade e beneficencia' o Príncipe reforça o Alvará de 18 de março de 1684 e a Carta de Lei de $1^{0}$ de julho de 1730, que já tratavam basicamente sobre os aspectos de sobrecarga dos navios, na tentativa de barrar a 'continuação de taes actos de barbaridade commetidos com manifesta transgressão dos direitos divino e natural' que podemos encontrar no em Alvará de 24 de novembro de 1813 (Soares, 2013).

Dentre as determinações relativas à higiene e alimentação, a lei limitava para cinco cativos por tonelada 0 total da carga das embarcações. Também fazia parte destas medidas o seguinte parágrafo:

$\S$ XII. Não sendo menos importante ocorrer e prevenir que não soffra a saude publica, por falta das necessarias cautelas no exame do estado em que chegam os negros ao porto do desembarque: e convindo que este se não permitta antes das competentes visitas da saude, e de se reconhecer que não há molestias a bordo que sejam contagiosas: ordeno que em todos os portos deste continente, e outros em que for permittido o desembarque de individuos esportados da Costa de Africa, haja de estabelerce-se um Lazareto separado da Cidade, escolhendo-se um logar elevado e sadio em que deva edificar-se, e naquelle Lazareto deverão ser recebidos os negros enfermos, para alli serem tratados e curados, até que os Facultativos a que forem commetidas as visitas do Lazareto, e o curativo dos doentes, os julguem em estado de poderem

\footnotetext{
${ }^{11}$ Manolo Florentino (1997, p.41) aponta que o caráter 'humanitário' das decisões vistas na Lei de Arqueamento estava vinculado as pressões britânicas para a abolição do tráfico.
} 
sahir para casa das pessoas, a quem vierem consignados. (SOARES, 2013)

Como ficou explícito nas palavras do Príncipe Regente, os Lazaretos deveriam ser instalados em todos os portos do continente que tivessem contato com o comércio negreiro. Afastados e elevados do nível da cidade, essas edificações seguiriam sua implantação conforme já estava sendo praticado no Valongo, demonstrando a preocupação já citada de replicar outros complexos como o do Rio de Janeiro em demais . Entretanto, neste período, o ‘complexo comercial' ainda não estava completo. O último equipamento urbano que finalizaria esse processo de aperfeiçoamento do mercado de cativos estava em construção: o Cais do Valongo. O primeiro registro sobre a determinação da construção do Cais é o atestado em que

(...) o regente Dom João demonstra publicamente que a obra não era um empenho isolado do Intendente, ou uma questão ordinária da gestão da cidade, mas um dos mais importantes benefícios que a presença do monarca e da família real trazia para seus súditos na América - como a Biblioteca Nacional, o Jardim Botânico, a Fábrica de Pólvora, entre outros magnânimos gestos da bondade real.

(SOARES, 2013, p.19)

Seguem as palavras do desembargador Paulo Fernandes Vianna no referido atestado:

'PAULO FERNANDES VIANNA do Conselho de Sua Majestade Real, Fidalgo Cavalheiro da Sua Real Casa, Comendador da Ordem de Cristo, Desembargador do Paço e Intendente Geral de Polícia da Corte e Estado do Brasil etc. Atesto que sendo ordem de Sua Alteza Real para mandar fazer uma rampa e cais correspondente a ele na praia do Valongo; e precisandose para esta obra de avultada porção de pedra, o tenentecoronel Julião José de Oliveira proprietário das pedreiras da Conceição a ofereceu gratuitamente toda a pedra que fosse necessária para aquela obra, ainda para outra qualquer que a polícia precisa fazer naquele sítio, tirada das suas pedreiras, cuja oferta foi aceita e se fez a mencionada rampa e cais com a pedra tirada das referidas pedreiras, no que a Intendência deixou de despender avultada quantia (...) Rio de Janeiro, 30 de maio de 1811.'

(AN, aforamentos, BR RJANRIO BI O D16 O O389. Folha 9. in SOARES, 2013, p.20)

Neste período 'o estado joanino já era sócio do comércio negreiro'. Os tributos cobrados, tanto na costa da África quanto nas cidades brasileiras iam para os cofres da Intendência Geral de Polícia da Corte do 
Rio de Janeiro, de onde saíram os valores necessários para a construção do Cais. Conforma destaca Soares,

\begin{abstract}
O cais do Valongo era a conclusão de um processo lento de modernização da área portuária da cidade do Rio, que teve lugar no século XVIII, quando o ouro das minas financiava o crescimento da urbe. O mais antigo cais de pedra do Rio foi o cais dos mineiros, ou cais de Brás de Pina, erguido nas proximidades do trapiche da cidade em 1736. Como o próprio nome indica, ele era voltado para o embarque do ouro quintado (tributado) para o Reino, como o cais do Ouro na Bahia. Depois dele somente em 1783 o estado ergueria um cais de pedra, desta vez na frente do Largo do Paço, obra do Vice-Rei Dom Luiz de Vasconcelos. E por fim o cais do Valongo. Três cais de pedra que simbolizavam os três níveis daquela sociedade. $\mathrm{Na}$ concepção do antigo regime, adaptado aos trópicos, cada um deles serviu a determinado estado (estamento social): o cais do Paço servia a aristocracia que assumia cargos no governo do vice-reinado; o dos Mineiros servia aos livres, pobres ou não, mas sem nobreza, que faziam o comércio com o interior da colônia; e, por fim, o Valongo era o cais de um certo terceiro estado, a escravatura, indispensável para a economia do país. (SOARES, 2013, p.20)
\end{abstract}

A construção de um cais específico para o recebimento de escravizados no Valongo reforçava o caráter segregacionista intrínseco à separação do comércio escravista do Centro da cidade. A presença deste espaço era a garantia de que ainda mais barreiras se construíram entre 0 soberano e o escravizado, aumentando o controle sobre os corpos africanos exportados para o Rio de Janeiro. Este desejo de dominação e restrição das ações dos cativos não era apenas evocado pelo tratamento que era destinados a eles, estava materializado no espaço, de modo que

(...) os africanos que desembarcaram no Valongo, desde a época de Dom João, logo na chegada eram alvo da vigilância da polícia, com um quartel construído pelo mesmo Intendente em frente ao ancoradouro, uma sombra que os perseguiria em qualquer parte da cidade.

(SOARES, 2013, p.22)

O referido desembarque começou a acontecer de forma parcial logo no primeiro ano da construção do cais que duraria mais cinco e custaria para os cofres públicos mais de 3 contos de réis, resultando em um espaço com extensão de '11 braças e meia da parte em terra e 10 braças e meia da parte do mar ou 24 metros e 22 metros respectivamente' (Soares, 2013, p.21). Este grande empreendimento, rapidamente refletiu seu impacto no comércio da região, sendo registrado um aumento de 
(...) 18.677 africanos desembarcados no ano de 1810 para cerca de 23.230 no ano de 1811, um aumento de $20 \%$. Somente em 1811 vemos a chegada de quase $10 \%$ de todos africanos tragados pelo Rio na era joanina.

(SOARES, 2013, p.22)

Este aumento significativo reforça a ideia de que a implementação de um 'complexo comercial' estruturado auxiliou na dinamização do comércio de escravizados, aumentando a produtividade e a velocidade com que se recebia, tratava e distribuía a mercadoria humana:

(...) a construção do cais do Valongo repercutiu um aumento considerável dos números de africanos escravos desembarcados no Rio. Somente nos três anos após o início de sua construção vieram mais $60 \%$ de africanos do que nos três anos anteriores. E podemos observar que até 1815 houve um aumento considerável da entrada de africanos na cidade, e justamente neste ano é publicada a lei que proibia o tráfico de navios do norte da linha do Equador e que deve ter tido um rápido impacto. Isto pode explicar a repentina e única queda nos números do tráfico até 1831 .

(SOARES, 2013, p.23)

Como também mostra Manolo Florentino (1997), o porto do Rio de Janeiro, já no século XVIII, 'desfrutava de um papel privilegiado no circuito Sul-Sul do tráfico Atlântico' sendo reforçada na centúria seguinte, consolidando-se como o 'principal centro de comércio de homens do Brasil'. Eram diversos os fatores que reservaram essa hegemonia ao Rio de Janeiro, sendo possível destacar que as abolições sucessivas no continente americano 'deixaram subsistir apenas dois grandes fluxos de africanos para a América: o tráfico para o Brasil e o que se destinava a Cuba'. Mesmo assim, o comércio de Cuba não superou o do Brasil, sendo possível afirmar que

(...) o tráfico carioca não encontrasse congênere mesmo em escala planetária, pois seu volume era superior aos 14.500 escravos que anualmente cruzavam o Sahara para os países árabes, o segundo maior fluxo de cativos do mundo no século XIX. Se o comércio negreiro se constituía como um mecanismo de produção econômica, então estes dados descartam categoricamente que a crise do chamado Antigo Sistema Colonial tenha assumido qualquer aspecto econômico. Ao contrário, a partir da emancipação de fato do Brasil, ocorrida em 1808 e reafirmada juridicamente em 1822, a secular economia escravista não só manteve intacto o seu mecanismo de reprodução, como também ampliou, mesmo tendo que entrar todo o tipo de pressão por parte da Inglaterra, a maior potência do Ocidente na época.

(FLORENTINO, 1997, p.68) 
Certamente dentro dessa ampliação apontada por Florentino, podemos incluir o desenvolvimento espacial do Valongo. Esse crescimento também ficou explícito no aumento dos armazéns de comércio de escravizados que praticamente triplicou durante esse período. Em 1817, havia pelo menos vinte grandes estabelecimentos no Valongo, mas cerca de nove anos depois, MacDouall calculou que havia cinquenta salas nas quais mais de 2 mil escravos estavam em exposição. (Karasch, 2000, p.75)

O depósitos onde armazenavam-se os cativos configuram mais uma tipologia de equipamento urbano encontrado no Valongo. Esses, por sua vez, eram geralmente grandes sobrados, que podiam ou não ser de propriedade do comerciante que o ocupava, dado que o aluguel de armazéns era muito comum nessa época.

Conforme o Valongo se consolidava como o local exclusivo para a venda de seres-humanos, os leilões públicos na porta da Alfândega foram paulatinamente proibidos, sendo que até 1821 ainda eram postados anúncios nos jornais divulgando tais atividades na região central da cidade. No entanto,

(...) quatro anos depois, o conselho municipal proibiu os leilões públicos de escravos naquele local, bem como sua exibição e vendo em mercados centrais e porta a porta. Continuou a permitir, porém, vendas públicas de escravos no Campo de Santana. Segundo Noronha Santos, um 'mercado branco' para a venda de todas as coisas e escravos ladinos existia ali desde 1821.

(KARASCH, 2000, p.89)

A proibição citada acima foi uma ordem da Câmara Municipal, emitida em 1824, tornando obrigatória a construção de armazéns para a comercialização de escravizados. Esta normativa conseguiu ser evitada pelos negociantes até 1847 quando foi inserido no Código de Posturas da cidade, no $§ 16$ na segunda seção a seguinte normativa:

$\S 16$. Ninguém poderá negociar em escravos sem ter para esse effeito armazém público em casa térrea ou loja, apresentando fiadores idoneos que se responsabilisem pelos prejuízos que ocasionar, assinando termo nesta Camara de não comprar escravos nem os receber para vender, senão de pessoas reconhecidas como seus legítimos senhores ou que apresentem pessoas estabelecidas como faes os afiancem. (Arquivo Geral da Cidade - Código de Posturas 1847. BR RJAGCRJ.CM.POM.2.2.001) 
É significativo que essa proibição vá aparecer somente em 1847, visto que nesse período o 'complexo comercial' do Valongo já estava desativado. $O$ que faz parecer que os negociantes, após perderem seu local específico de comércio, precisaram integrar-se novamente com a dinâmica da cidade. Porém, antes de sua desativação com a lei de 7 de novembro de 1831, o Valongo viveu seu maior pico de atividades. Segundo Soares (2013),

\begin{abstract}
No período de maior movimento, entre 1821 e 1831, mais de 250 mil africanos teriam galgado os degraus de granito do cais do Valongo, o que aponta que o cais de pedra do Valongo responde por metade do um milhão de escravos mandados para o Rio nos 50 anos entre 1779 e 1831 . Com a lei de 7 de novembro de 1831 o cais não mais recebeu navios vindos diretamente da África, se bem que ainda recebesse o tráfico de escravos de outras províncias do Império do Brasil (que muitas vezes disfarçava o tráfico Atlântico clandestino). O cais caiu no esquecimento até 1843 quando novo ancoradouro foi construído por cima daquele, para receber a Princesa de Nápoles, esposa do imperador Pedro II, em 1843.
\end{abstract}

(SOARES, 2013, p.24)

O fim do 'complexo comercial' do Valongo não levou consigo o comércio de escravizados no Rio de Janeiro, pelo contrário. As atividades comerciais foram transferidas para as praias mais distantes da cidade, o que significou também um tratamento ainda mais cruel dos comerciantes para com os cativos que agora eram negociados na ilegalidade, onde

\begin{abstract}
(...) não havia tempo nem lugar para que os novos africanos descansassem e se recuperassem da longa jornada, exceto se o lugar de desembarque tivesse um barracão cuidadosamente escondido no qual pudessem ser alimentados e vestidos antes da marcha forçada até as fazendas ou ao Rio. Suspeita-se que embarques rudes e apressados e longas marchas - talvez de trinta a oitenta quilômetros depois de atracar para evitar os cruzadores britânicos - aumentavam as agruras e as taxas de mortalidade dos novos africanos.
\end{abstract}

(KARASCH, 2000, p.75)

Com a proibição do tráfico e a inutilização do Valongo como mercado, a região começa a passar por sucessivos processos de soterramentos históricos, pontuados por demolições e remodelações no espaço físico. A primeira tentativa de sobreposição dos tempos obscuros do Valongo foi o já citado Cais da Imperatriz, em 1843, que teve pouco tempo de vida, encontrando-se em 1850 já considerado esquecido.

Posteriormente, no dia 15 de setembro de 1871, foi lançada a pedra fundamental do projeto Docas Predo II, concluída em 1875, sem a 
utilização de mão de obra de escravizada como assim definiu o engenheiro negro responsável André Rebouças. Mesmo sendo uma iniciativa privada, a proposta de criação da rede de docas que ocuparia todo o litoral até a Gamboa teve forte apoio do Estado. Entretanto a função original do projeto nunca foi alcançada, servindo principalmente como depósito do café que chegava na Estação do Campo de Santana ${ }^{12}$.

\begin{abstract}
Uma das funções mais importantes das docas planejadas por Rebouças era levar os trilhos da Estrada de Ferro Dom Pedro II para o mar, facilitando enormemente o embarque do café que vinha do interior nos vagões da Companhia, mas que tinha de ser transportada em lentas carroças para entrar na cidade e chegar aos vapores. Em algum lugar da Gamboa haveria um terminal marítimo onde o café fosse embarcado sem o uso das primitivas carroças.
\end{abstract}

(SOARES, 2013, p.35)

A modernização da região portuária, após o período escravista, sempre foi motivo de muita agitação, principalmente por parte dos donos de trapiches na região, como assinala Soares (2013),

As inúmeras tentativas de apagamento das narrativas que compõem a história do Valongo foram muitas e sistemáticas, incluindo a mudança de nomes de ruas, demolições, reconstruções e silêncios. O que nunca mudou na região, desde os tempos do comércio de escravizados, é a presença de corpos negros que permanecem contando suas histórias de luta e resistência, nem sempre ouvidas, mas intensamente vividas.

A Zona Portuária do Rio de Janeiro ganhou a alcunha de Pequena África, visto a concentração de negro-africanos que sempre povoaram seu território e arredores, mesmo depois da abolição. Já no século XX, o

\footnotetext{
12 "Todos os projetos de reforma portuária esbarravam no poder político dos donos de trapiches, cujos representantes ocupavam papéis chaves na Câmara Municipal. Por mais que o cais da Imperatriz cada vez mais ficasse para trás a medida que as precárias pontes de madeira estendiam, o entorno da Praça Municipal [construída em 1843 como parte do projeto de remodelação do antigo Valongo] não perdia sua importância no conjunto portuário do Rio. Em 1899, no limiar do novo século - e já com vários projetos ameaçando claramente sua existência um novo trapiche é erguido ao lado da praça: o trapiche Ipiranga. Era um trapiche incomum, pois boa parte era de alvenaria, com rebuscado estilo neoclássico na fachada, e longa ponte construída, colado na antiga praça Municipal. Nenhum trapiche privado do Rio, em toda história da rede portuária, teve tão grande área construída com alvenaria. Tudo isso reforça a ideia que o entorno da Praça Municipal, incluindo o Valongo, depois o cais da Imperatriz, a Doca Pedro II e o trapiche Ipiranga, formam a região mais importante de todo litoral norte do Rio no século XIX, como um imenso campo de provas das mais modernas tecnologias das suas respectivas épocas." (SOARES, 2013, p.28)
} 
pintor e sambista Heitor dos Prazeres cria este nome para contemplar também a forte presença de expressões religiosas e culturais de matriz africana $^{13}$.

Foi através das escavações realizadas na região para a execução de obras de infraestrutura urbana, em 2011, que retornaram das profundezas as antigas pedras do Cais do Valongo, causando espanto em alguns e satisfação em muitos. Após extenso trabalho de arqueologia urbana e recuperação histórica, o Cais do Valongo ganhou em 2017 o título de Patrimônio Mundial da Humanidade, concedido pela UNESCO.

Atualmente uma pequena janela arqueológica espremida no meio das ruas asfaltadas nos dá a oportunidade de encarar todos os dias esse assombroso momento da história e, acima de tudo, permite que os pés que antes sangravam acorrentados possam pisar as mesmas pedras em busca de novos caminhos, novas trajetórias, em busca do antigo sonho de liberdade.

\subsection{Programação da morte}

Conforme acompanhamos até o momento, o complexo comercial do Valongo era composto basicamente por quatro aparelhos que funcionavam de forma autônoma, porém interligados, eram eles: os depósitos e armazéns, espaços em que eram mantidas as 'mercadorias humanas' e que já se faziam presentes em grande número na região antes mesmo da transferência oficial do mercado; o Cemitério dos Pretos Novos, local em que era feito o descarte dos corpos dos cativos que não resistiam a viagem ou as violência praticadas nos armazéns; o Cais do Valongo, espaço de recebimento e distribuição dos cativos e de outras mercadorias que vinham pelo mar e, por fim, o Lazareto da Gamboa onde eram realizadas as quarentenas impostas pelas autoridades de saúde para garantir a vacinação e o tratamento médico dos africanos que poderiam 'trazer consigo' alguma doença de sua terra natal (Dossiê, 2017, p.21).

\footnotetext{
${ }^{13}$ Para um panorama abrangente das diversas realidades sociais na região no pós-abolição ver Dossiê Cais do Valongo (2017).
} 
Todos esses aparelhos funcionavam de forma ordenada, criando uma espécie de rede instalada diretamente no sistema escravista. O bom desempenho das atividades no Valongo dependia em grande parte da interface constante entre os diversos espaços que o constituíam, bem como com alguns pontos fora do complexo, tendo sempre o mesmo objetivo: produzir a 'morte social' do escravizado através da violência ao seu corpo e violação da sua subjetividade.

Nessa última parte do segundo capítulo serão analisadas as etapas desta 'programação da morte' e as especificidades que os principais tipos de transação comercial possuíam, para que com isso seja possível delinear os trânsitos e dinâmicas espaciais ocorridas no interior do complexo comercial do Valongo. Neste espaço cada passo dado pelo cativo significava mais uma etapa cumprida no processo de 'metamorfose' da sua vida em mercadoria.

Sobre tal, é possível afirmar como ponto de partida que os modos com que essa 'metamorfose' se desenrolava tinha um procedimento próprio que poderia ocorrer em um ou mais lugares diferentes. Essas diferenças davam-se em sua maioria pela natureza do escravizado, sua identidade e seu valor de mercado. Os espaços físicos, e o deslocamento por eles seguiam conforme o programa de morte específico de cada grupo de cativos, definindo quais mecanismos seriam acionados pelo seu negociador no processo de venda.

Ao falar da identidade de um escravizado, e de como esse fator poderia definir os seus caminhos no mercado, podemos destacar três aspectos importantes levantados por Mary Karasch (2000): sua condição de escravizado 'novo' ou 'usado', quem o comercializava e o complexo gênero-idade.

A identidade de um escravo afetava claramente a maneira pela
qual era vendido no mercado, que oferecia diferentes
mecanismos para a venda de escravos novos ou 'usados'.
Embora os meninos africanos tivessem de encarar exibições e
leilões públicos, mulheres brasileiras mais velhas podiam ser
vendidas na privacidade para um amigo ou parente de seu
senhor. Em reconhecimento das diferenças entre escravos, os
proprietários e negociantes arranjavam várias estruturas
comerciais informais, ilegais ou autorizadas para comprar e
vender escravos novos e ladinos na cidade do Rio e nas
províncias. (KARASCH, 2000, p.72) 
É importante salientar que a noção de identidade, conforme levantada por Karasch, está ligada aos aspectos que serviam como identificação do escravizado enquanto mercadoria e coisa vendável; fatores culturais ou subjetivos de autodefinição dos negro-africanos não são levantados como determinantes, mas sem dúvidas eram fundamentais no processo. As categorias apresentadas são todas atribuídas por esferas externas aos cativos e alheias à sua vontade ou poder de escolha, estabelecidas pelos seus comerciantes e senhores. Mesmo a idade que é uma característica biológica/orgânica do sujeito aparece nesse contexto como decisivo na relação custo-benefício de sua existência enquanto produto.

Desse modo, temos o primeiro critério de divisão dos escravizados para a comercialização: os que eram africanos 'novos', que haviam recém-chegado de sua terra de origem e os africanos ladinos, que já eram 'usados'. Uma das principais ressalvas sobre os dois grupos eram suas capacidades laborais. Enquanto os escravizados novos eram africanos recém-importados, os ladinos eram sujeitos assimilados no Rio de Janeiro ou até mesmo nascidos no Brasil. Essa característica conectava-se diretamente com o fato de que o africano recém-chegado poderia não estar 'treinado' ou não possuir as habilidades para o trabalho, diferente do ladino que muitas vezes representava uma mão de obra capacitada. Essa divisão não só identificava as características do produto a ser vendido como também abria diferentes métodos de comercialização.

Os documentos oficiais de licença para o comércio também se alteravam conforme a natureza da mercadoria vendida. Os proprietários poderiam ter licenças para o comércio de escravizados 'novos, ladinos ou para ambos os $\operatorname{casos}^{14}$. Cada tipo de mercadoria exigia uma modalidade de venda e possuía características próprias, tanto na sistematização como no seu desenvolvimento no espaço físico, demandando programações e estruturas específicas para cada caso.

\footnotetext{
14 "Como esclarecem os documentos, o uso pelos negociantes das palavras 'novo' e 'ladino' sugere que faziam distinção entre os novos na escravidão e os anteriormente escravizados." (KARASCH, 2000, p.68)
} 
O segundo fator era 'quem' estava realizando a transação, o que determinaria se a venda ocorreria dentro ou fora do Valongo. Nem todas as transações ocorriam nos espaços licenciados, alguns escravizados eram repassados entre senhores através de acordos que aconteciam entre eles de forma privada, esse tipo de acordo tornou-se ainda mais comum após 1830 quando o comércio transatlântico de seres-humanos foi proibido e a mercadoria passou a ser vendida de forma ilegal. Karasch (2000, p.68) afirma que "(...) os mais afortunados conseguiam evitar a venda pública", referindo-se a esses como os que tinham a sorte de escapar das mazelas e dos transtornos das exibições públicas e de todos os horrores do Valongo.

Por fim, temos o coeficiente gênero-idade. Esse aspecto interferia não só na forma como se daria a sua venda, mas também na maneira como o escravizado encarava a experiência no mercado. Segundo relato de viajantes e dados sobre a importação na época, os escravizados oferecidos, em sua maioria, constituíam um grupo homogêneo: pessoas do sexo masculino com idade entre 10 e 24 anos. Esta faixa etária indicada pelos relatos estava ligada ao desempenho de vendas no mercado, como é possível constatar a seguir:

\begin{abstract}
Um observador preciso, o alemão Freireyss, chegou a estimar que três quartos dos negros importados eram crianças (18141815). Outros estrangeiros eram menos específicos e apenas supunham que as crianças mais jovens no mercado tinham mais de cinco ou seis anos (...) No entendo, outros viajantes apontavam para uma idade um pouco maior, geralmente entre doze e catorze anos. Já em 1807, Vaux registrava que o melhor escravo para comprar era um jovem de quinze anos e ainda em 1848, Ellis observava que, em geral, vendiam-se melhor os meninos entre doze e catorze anos.

(KARASCH, 2000, p.69)
\end{abstract}

Obviamente existia uma oferta grande de pessoas de diversas idades, mas ou os meninos eram de fato uma preferência dos compradores ou existia alguma dificuldade com relação ao tráfico de mulheres. Os dados sobre importação apresentados por Karasch dizem respeito ao período de 1830 - 1841 e deixam clara a

(...) preferência por escravos masculinos, mas documenta principalmente que os negociantes tendiam a importar mais meninos do que homens, mulheres ou meninas. Nesse caso, quase $43 \%$ dos que estavam nos navios negreiros eram meninos. $\mathrm{O}$ grupo com menos probabilidade de importação era 
o das mulheres adultas, que compunham apenas $7 \%$ das cargas.

(KARASCH, 2000, p.70)

Seguindo o caminho aberto pelos estudos apresentados até 0 momento podemos encontrar pelo menos cinco métodos diferentes de venda, que incluíam locais e dispositivos específicos. O primeiro deles era o que, aparentemente, fazia o escravizado passar por mais estágios dentro do Valongo antes de chegar às mãos dos futuros proprietários era o comércio de 'pretos novos'.

Os navios negreiros que chegavam ao Rio de Janeiro com seus porões carregados passavam por inspeções e procedimentos de rotina antes de serem autorizados a colocar os africanos recém-chegados em barcos a remo menores e levá-los até a alfândega, localizada no distrito comercial $^{15}$. Para alguns essa primeira parada poderia significar a última, visto que muitos leilões aconteciam ali mesmo, logo após a contagem e o pagamento de impostos realizado pelo responsável da embarcação.

Porém, quando os agentes de saúde identificavam algum problema grave, como doenças ou epidemias, os escravizados eram encaminhados para a quarentena. Como visto anteriormente, a quarentena antes de 1810 acontecia fora do Valongo. Após a construção do Lazareto da Gamboa, os africanos já entravam no espaço do complexo comercial assim que passavam pela alfândega. Cumprido o período de quarentena, ou caso não fosse necessário, os cativos eram direcionados aos armazéns dos seus respectivos comerciantes.

Por meio dos relatos dos viajantes, é possível criar dois cenários sobre as condições com que os africanos eram mantidos nestes armazéns, bem como as próprias condições dos mesmos. Numa visão mais positiva, alguns estrangeiros descreviam as casas onde vendiam-se os escravizados como 'muito excelentes' e até mesmo 'verdadeiros palácios' (Karasch, 2000, p.75 e 76). Através de tais relatos, Mary Karasch descreve o que poderia ser essa visão otimista de alguns viajantes nas palavras a seguir,

\footnotetext{
15 "Na alfândega, cobrava-se imposto apenas sobre escravos com mais de três anos de idade, mas os menores que isso também eram registrados." (KARASCH, 2000, p.68)
} 
Enquanto a família do negociante de escravos morava nos andares superiores, o térreo do 'palácio' abrigava os novos africanos. Ali havia um grande vestíbulo que abria para pequenos pátios com bancos baixos. Em muitos casos, era o pátio que fazia as vezes do assim chamado armazém ou depósito de escravos. Abertos ao sol e à chuva, os pátios abrigavam os africanos enquanto se recuperavam e esperavam para serem vendidos. Uma vez que a família do negociante morava no segundo andar, os pátios eram mantidos 'muito limpos' e lavados várias vezes por dia. Devido à proximidade da baía, a brisa marinha refrescava os pátios e renovava o ar. (KARASCH, 2000, p.76)

Ao passo que alguns relatos descrevem as condições 'favoráveis' aos quais os africanos eram mantidos, outros apresentam uma visão um pouco mais condizente com o que a maioria dos vestígios nos mostra de forma ostensiva. Um desses contrapontos é o relato realizado pelo inglês C. Brand que segue,

A primeira loja de carne em que entramos continha cerca de trezentas crianças, de ambos os sexos; o mais velho poderia ter doze ou treze anos e o mais novo não mais de seis ou sete anos. Os coitadinhos estavam agachados em um imenso armazém, meninas de um lado, meninos do outro, para melhor inspeção dos compradores; tudo o que vestiam era um avental xadrez azul e branco amarrado na cintura; [...] O cheiro e o calor da sala eram muito opressivos e repugnantes. Tendo meu termômetro de bolso comigo, observei que atingia $33^{\circ} \mathrm{C}$. Era então inverno [junho]; como eles passam a noite no verão, quando ficam agachados, não sei, pois nessa sala vivem e dormem, no chão, como gado em todos os aspectos.

(BRAND, apud KARASCH, 2000, p.76)

A visão que consternou o viajante inglês, fazendo-o pensar em como seria a situação em períodos diferentes do ano, de fato não representava a pior das condições com que os negro-africanos eram mantidos nos armazéns. Como apontado por Brand, a sua visita deu-se no inverno, período este que normalmente registrava os menores índices de desembarque, sendo o alto verão o pico de movimentação de mercadorias no comércio negreiro como mostra Florentino (1997),

(...) o movimento de negreiros possuía um padrão geral: tendia a atingir o pico nos meses de dezembro/janeiro, decrescendo um pouco entre fevereiro e maio; com o inverno no hemisfério sul, as flutuações atingiam seu nível mais baixo, só se recuperando a partir de agosto, quando a tendência ascendente se impunha, para mais uma vez atingir o pico no alto verão.

(FLORENTINO, 1997, p.61)

Essa discrepância nas percepções sobre os armazéns e as condições de tratamento com relação aos escravizados devem-se, 
segundo Karasch (2000), a esses períodos de sazonalidade dos desembarques, que significavam uma diminuição na importação. Se um viajante passasse pelo Valongo em um período de baixa movimentação nos negócios possivelmente encontrariam os cativos sendo 'bem tratados' e vivendo em espaços sem excesso de lotação ${ }^{16}$.

As condições em que os escravizados africanos eram mantidos nos armazéns de fato era altamente violenta e desumana. Além da precariedade dos ambientes onde eram mantidos como mercadoria, a venda era também extremamente agressiva, incluindo maus tratos, péssima alimentação e constante violação física dos corpos encarcerados que "eram expostos muitas vezes completamente nus para melhor inspeção dos compradores" (Karasch, 2000, p.78).

Durante todo esse processo, visto que os cativos estavam constantemente expostos a morte, o Cemitério dos Pretos Novos poderia ser a última parada de um africano 'novo' dentro de sua passagem pelo Valongo. O cemitério era constantemente alimentado com cadáveres dos que não suportavam as inúmeras agressões que sofriam dentro e fora das 'lojas de carne'. O alto índice de mortalidade se reflete no número de enterramentos onde,

“(...) verificamos que de 1824 a 1830 foram sepultados 6.119 escravos no Cemitério dos Pretos Novos, o que daria o número de 1.019 sepultamentos por ano." (PEREIRA, 2007, p. 87)

O segundo método de venda era destinado aos escravizados 'usados', ou ladinos, que eram comercializados em caráter de revenda. Os senhores que quisessem, por qualquer razão, vender um escravizado de sua propriedade ou até mesmo alugar os seus serviços, poderia procurar um estabelecimento que desempenhasse essa função no mercado do Valongo. Dentre eles estavam "as casas de comissão ou

\footnotetext{
16 "Aparentemente, os abusos mais terríveis ocorriam nos períodos de importação pesada. Por exemplo, os registros da alfândega revelam que 786 africanos foram contados em maio de 1822, em comparação com 4401 em março. Além disso, os esforços do governo em confinar os novos africanos em armazéns fechados devem ter aumentado seu sofrimento, em especial durante os meses quentes, quando centenas deles eram encerrados em depósitos sem janelas."

(KARASCH, 2000, p.76)
} 
consignação, casas de leilão, lojas de varejo e os jornais, por meio de anúncios" (Karasch, 2000, p.85).

As possibilidades de negociação de um escravizado ladino eram inúmeras e por isso mesmo dificultavam a regulação, por parte, do governo da cidade, o que acarretava em diversos processos que aconteciam sem licença. Desta maneira, era muito comum que negociantes oferecessem escravizados ao lado de outros produtos em suas lojas ${ }^{17}$. Haja vista que também não possuíam armazéns e nem eram obrigados a fazê-los, não se consideravam comerciantes de escravizados e por isso operavam sem licença.

Em contrapartida as casas de comissão eram espaços licenciados e que trabalhavam com duas formas diferentes de autorização legal. Os pedidos de licença demonstram que

\begin{abstract}
(...) havia dois tipos dessas casas: as licenciadas para comprar e vender qualquer produto, inclusive escravos, em nome de seus clientes; e aquelas limitadas a artigos valiosos, como ouro, casas, terra e escravos. As últimas tinham permissão também para dar crédito contra objetos de valor, tais como escravos, recebidos em caução.

(KARASCH, 2000, p.86)
\end{abstract}

As casas licenciadas que comercializavam produtos diversos estavam conectadas ao comércio direto com fazendeiros e seus comissários, realizando compras e vendas de escravizados que estavam constantemente em trânsito interprovincial. Dessa forma, os escravizados eram expostos junto com outros produtos que também eram enviados pelos fazendeiros para o comércio no Valongo.

Em particular, os senhores do Nordeste utilizavam seus
comissários no Rio para vender escravos a fim de pagar
dívidas em épocas de seca e fracasso de colheitas. Quando
esses escravos chegavam à corte eram depositados com
outras mercadorias consignadas ao comissário. Assim, ficavam
muitas vezes junto com sacos de açúcar até que o comissário
encontrasse um comprador para eles. (KARASCH, 2000, p.86)

Já as casas com licença para comercializar produtos valiosos faziam a exposição dos cativos com outros objetos de valor e também realizavam leilões e aluguéis. Algumas dessas casas do segundo tipo,

\footnotetext{
17 "Os ladinos viam-se muitas vezes à venda ao lado de vasos de cerâmica, lamparinas de estanho e colheres de pau." (KARASCH, 2000, p. 85)
} 
inclusive, realizavam apenas o serviço de aluguel de escravizados, sendo contrários a exigência do conselho de que construíssem armazéns para abrigar a sua mercadoria ${ }^{18}$.

Ainda nessa variação de venda de escravizados ladinos, podem ser encontradas as casas de consignação licenciadas, que eram estabelecimentos com uma abrangência menor, mas que mantinham os escravizados alimentados e guardados em armazéns no Valongo. Esses estabelecimentos restringiam-se apenas ao comércio de escravizados e quando recebiam um número muito grande de mercadoria anunciavam o dia da venda em jornais. $\mathrm{Na}$ data marcada, os compradores iam até os armazéns e, provavelmente, prosseguiam a compra nos mesmos moldes que os compradores de pretos novos, através de exibição pública e inspeções físicas (Karasch, 2000, p.88).

Uma terceira modalidade de venda era a praticada pelas casas de leilões. Nesse procedimento eram comercializados tanto escravizados novos como ladinos. Enquanto as casas de comissão estavam mais relacionadas com as transações com fazendeiros, as casas de leilão concentravam-se em atender a qualquer um que se propusesse a arcar com as taxas ${ }^{19}$.

Inicialmente, os leilões eram realizados em locais públicos, como na porta da alfândega ou pelas ruas do distrito comercial. Porém, em 1825 o conselho municipal lançou uma proibição dessa prática restringindo sua atuação a locais confinados e armazéns, onde os escravizados eram negociados junto com outros objetos de valor. Eram catalogados, vendidos e descritos da mesma forma que cavalos, móveis e outros objetos de segunda mão. Separados por cercados e expostos a descrição e humilhação pública, os escravizados eram leiloados pelo menos uma vez por semana, mas também poderiam ser vendidos pelas casas diretamente com os compradores, fora do leilão.

\footnotetext{
18 "(...) apesar dos protestos sobre o regulamento de 1846 que exigia armazéns, a decisão final foi que todos que negociavam com escravos, inclusive os comissários deviam ter armazéns." (KARASCH, 2000, p.517)

19 "Uma vez que estavam limitados a realizar essas vendas em leilões públicos por uma comissão, os leiloeiros não estavam tão envolvidos no tráfico interprovincial quanto as casas de comissão." (Ibid. p, 88)
} 
Esse tipo de prática abre as portas para o quarto método de venda de cativos: as transações em lojas de varejo, anúncios e contatos pessoais. Alguns comerciantes compravam sua mercadoria humana direto dos armazéns ou utilizava os jornais para manter contato direto com proprietários interessados em repassar suas propriedades e depois revendiam os cativos com uma margem de lucro.

Os jornais também eram utilizados por senhores que queriam vender seus cativos, mas evitavam o Valongo. Esse método era muito utilizado para a venda de escravizados valiosos, que estavam a serviço de seus senhores por muito tempo e que tinham seu trabalho valorizado pelos mesmos. Geralmente, esses negócios através de contatos pessoais davam-se entre amigos, familiares e sócios, em ambientes privados. Alguns senhores também doavam seus escravizados. Esse método era muito utilizado para demonstrar riqueza, prestígio ou até mesmo para que um escravizado doente ou inválido fosse repassado como forma de caridade.

Sobre esses métodos, Mary Karasch (2000) afirma que eles eram uma forma de os escravizados 'escaparem' dos transtornos causados pela experiência do Valongo. Podemos encontrar em suas palavras a seguinte passagem sobre essa afirmação:

\begin{abstract}
Os escravos que eram vendidos ou doados por seus donos a amigos, parentes e contatos sociais escapavam da degradação do processo de compra. Por meio e transações informais e pessoais, mudavam de dono com menos trauma que os submetidos a leilões públicos ou vendas em lojas e armazéns lotados. Mas esses escravos eram os felizes favorecidos: crianças criadas nas famílias, criados domésticos e aqueles com habilidade especiais que aumentavam seu valor de mercado. Somente uma pequena elite e, portanto, uma porcentagem pequena dos escravos nascidos no rio evitava uma transação de sua pessoa. A vasta maioria dos escravos cariocas passava pelo trauma e a insegurança de ao menos uma venda em suas vidas. Poucos tinham qualquer garantia de que seus donos os manteriam em suas famílias e cuidariam deles pelo resto de suas vidas.
\end{abstract}

(KARASCH, 2000, p.92)

Se a 'sorte' estava ao lado dos que conseguiam evitar os traumas do Valongo, o mesmo não pode ser dito pelos escravizados que eram comercializados no último método levantado: o tráfico com o interior. Essa modalidade de comercialização de cativos era a mais temida entre os 
próprios escravizados. Esse medo pode ser explicado pelas condições com que os africanos eram conduzidos até o seu destino. Segundo o que os registros sugerem

(...) entre seus maiores medos estava o rapto e a venda fora da cidade (...) Parte da sua relutância em deixar a cidade talvez se devesse ao conhecimento da maneira árdua pela qual teriam de viajar ao interior. Embora os novos africanos não tivessem ninguém para Ihes contar sobre sua próxima jornada, os escravos cariocas de há muito observavam os comboios de negros caminhando para o interior ou haviam conversado com gente que chegada de outras províncias em navios apinhados. Em geral, o que esses escravos suportava no tráfico interno não era uma experiência uniforme, pois dependia de quem os comprava, de que modo eram transportados por terra ou por mar, para onde estavam indo e quem, entre uma 'multidão de intermediários', os conduziria.

(KARASCH, 2000, p.93)

Uma das práticas comuns era a organização de pequenas caravanas que partiam do Rio de Janeiro até as fazendas do interior. Alguns grupos tinham que suportar desgastantes caminhadas até Cuiabá e Mato Grosso. Era comum que aventureiros, como mascates e tropeiros largassem suas antigas profissões e comprassem escravizados a crédito no Valongo para organizar expedições como essa. Desse modo,

Tal como os que apregoavam escravos de porta em porta, saíam para vendê-los de fazenda em fazenda. Assim que vendiam todos, retornavam ao Rio para pagar suas dívidas, obter novo crédito e repetir o processo.

(KARASCH, 2000, p.98)

Essa condição ilegal dos escravizados traficados nesse método faz eco com o que ocorria após 1830, após a desativação do Valongo quando o comércio de escravizados já era ilegal no país, e a demanda ainda era muito grande, como descrito a seguir,

Durante a década de 1830, não havia tempo nem lugar para que os novos africanos descansassem e se recuperassem da longa jornada, exceto se o lugar de desembarque tivesse um barracão cuidadosamente escondido no qual pudessem ser alimentados e vestidos antes da macha forçada até as fazendas ou ao Rio. Suspeita-se que embarques rudes e apressados e longas marchas - talvez de trinta a oitenta quilômetros depois de atracadas para evitar os cruzados britânicos - aumentavam as agruras e as taxas de mortalidade dos novos africanos.

(KARASCH, 2000, p.75)

Com esse panorama realizado nesta etapa da pesquisa, é possível confirmar que as relações entre o espaço físico construído do Valongo e a 
organização social que ditava a dinâmica do complexo comercial estavam estritamente ligadas. Os espaços foram pensados e construídos de modo a otimizar as práticas de recebimento, manutenção, distribuição e descarte de milhares de vidas de negro-africanos que tinham como destino as transações comerciais escravistas. As necessidades dos comerciantes, bem como os anseios do Estado e das elites locais definiram os rumos e a velocidade com que se deu a consolidação urbana do espaço do Valongo. As informações levantadas até o momento permitiram a sistematização do percurso básico realizado pelos escravizados no interior do complexo comercial do Valongo (Figura 3, 4, 5 e 6). Além dos fluxos, o que também começa a se tornar latente é o papel preponderante da ação sobre o espaço, seja na constituição de edificações ou no ordenamento de atividades realizadas no território.

Assim como visto no capítulo inicial, a ocupação da cidade do Rio de Janeiro estava diretamente ligada às intenções definidas pela soberania escravista, que ao aplicarem seus padrões de controle construíam limites visíveis e invisíveis para delimitar os lugares físicos e sociais que dividiam os soberanos (branco-europeu) dos subalternos (negro-africanos). Nesse contexto, o mercado de escravizados do Valongo exprimia ao mesmo tempo um desejo de compartimentação do espaço, típico da ação escravista, com uma necessidade comercial e econômica, incentivada pelo Estado e pelas elites locais. Essa ação conjugada de forças acarretou diretamente na criação de espaços específicos que serviam como mecanismos de efetivação das estratégias de dominação que tinham como alvo o negro-africano escravizado, sendo o Valongo parte fundamental de todo esse processo. 


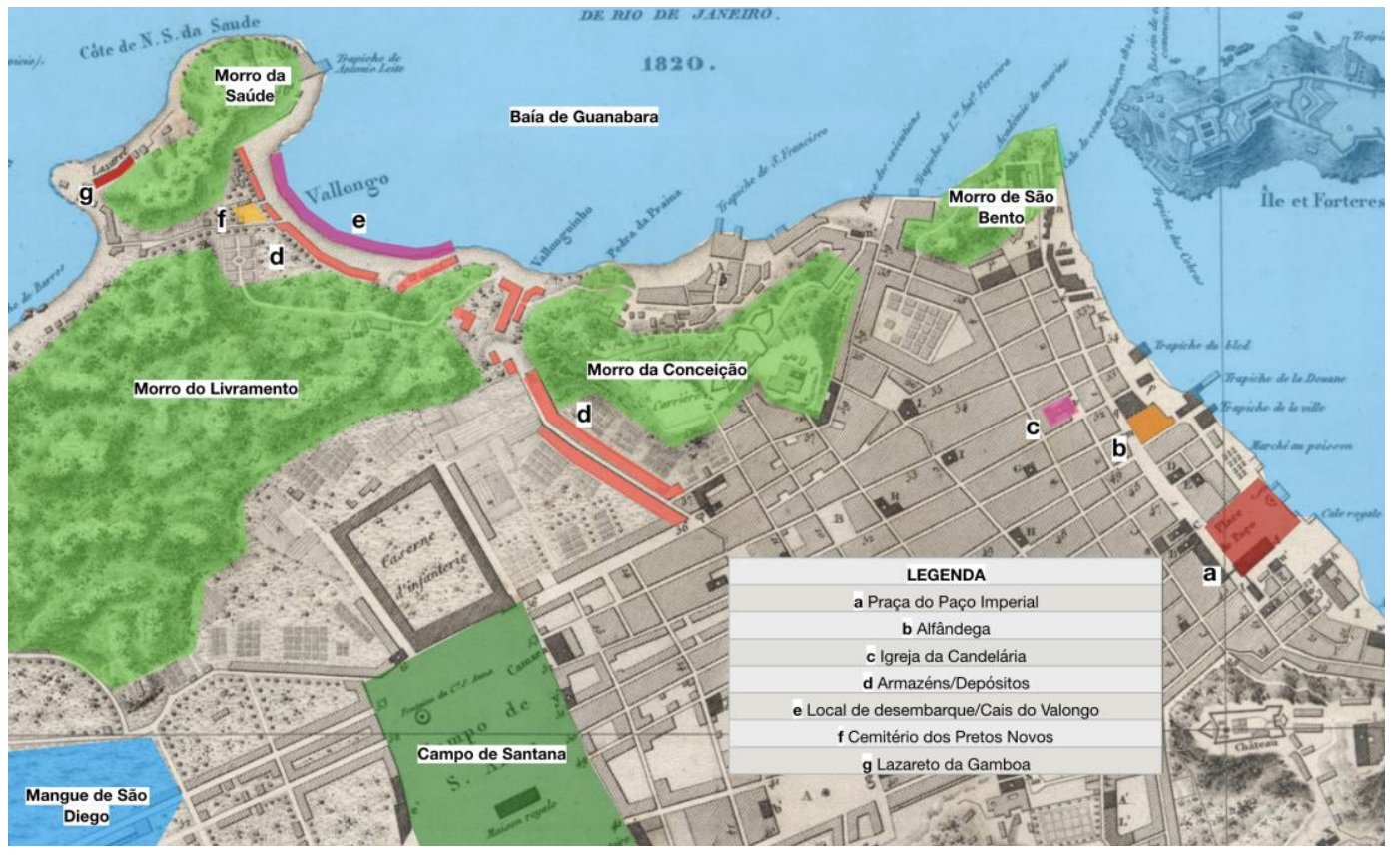

Figura 3. Valongo e os principais elementos do entorno.

Fonte: Do autor

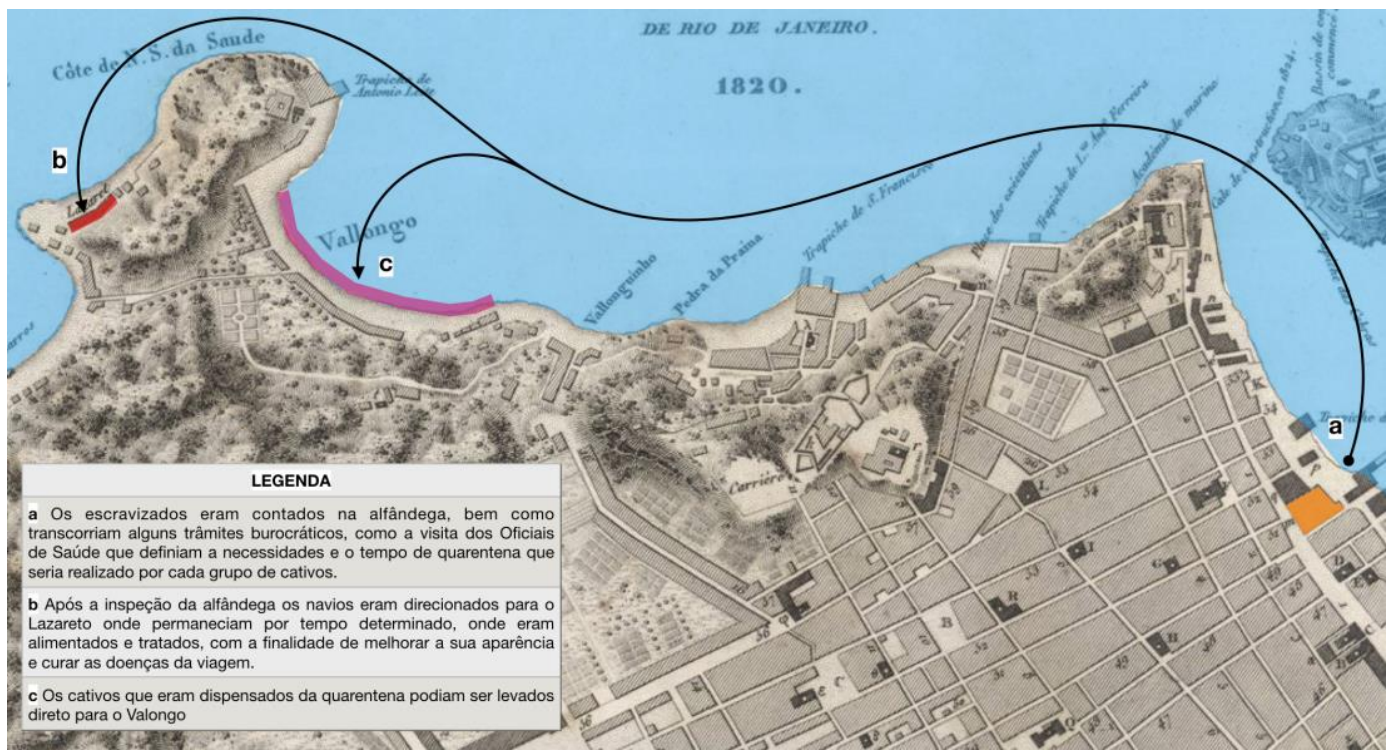

Figura 4. Trânsito dos cativos no Valongo - etapa 1

Fonte: Do autor 


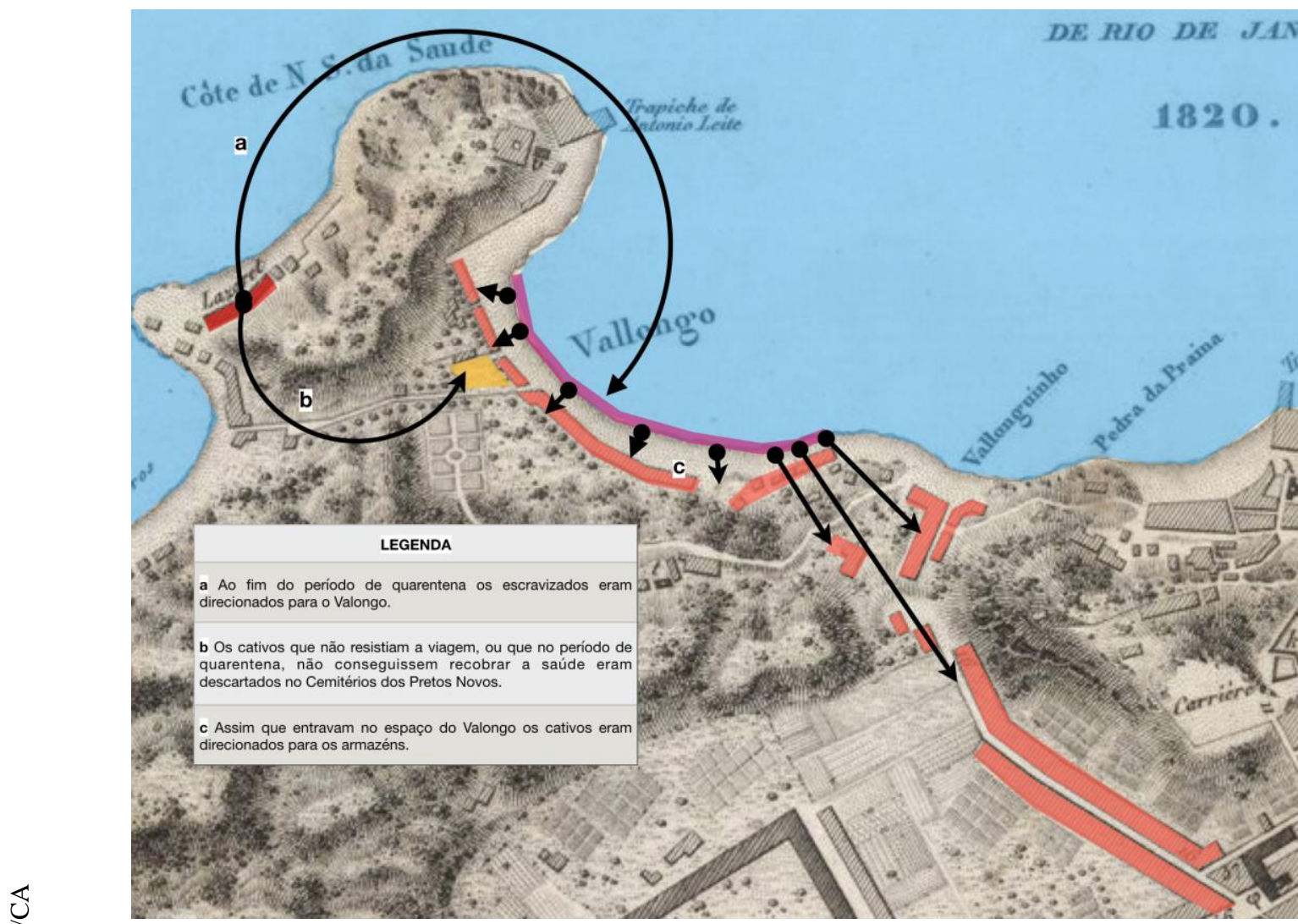

\section{Figura 5. Trânsito dos cativos no Valongo - etapa 2}

Fonte: Do autor

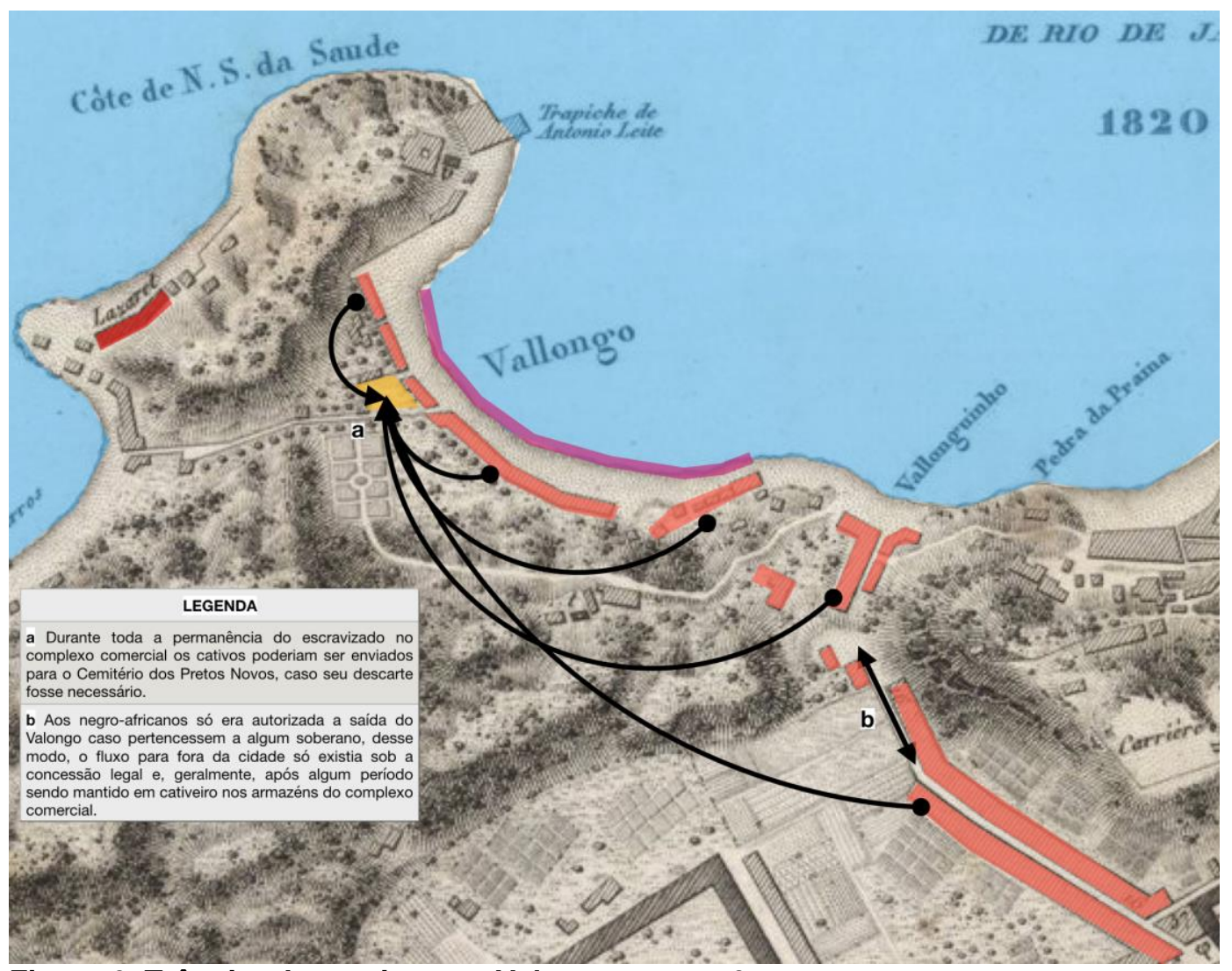

Figura 6. Trânsito dos cativos no Valongo - etapa 3

Fonte: Do autor 
O que se pretende compreender a partir de agora é como a materialidade e as formas de ocupação destes espaços dentro do complexo comercial do Valongo guardavam em sua dimensão mais tangível os elementos que definiam seu papel dentro das relações de poder. Porém, antes de seguir os caminhos que levam para o interior dos armazéns abarrotados ou às pilhas de corpos incinerados no Cemitério dos Pretos Novos, é preciso entender de que forma a violência e o terror viraram não só os meios, mas a própria finalidade de tais ações; tornando a governabilidade e a gestão da morte elementos centrais. 


\section{Necroarquitetura: o poder pela estrutura}

A existência de um espaço como o complexo comercial do Valongo está amparada em um programa de poder típico do sistema escravista conforme praticado pela Europa durante o seu projeto de colonização: a 'necropolítica'. Esse conjunto de técnicas e diagramas de poder, que tem como objetivo a morte, desenvolveu-se a partir de diversos processos de efabulação e autoficção do sujeito branco-europeu que, ao afirmar-se como superior ao negro-africano, sentiu-se autorizado a explorar de forma ostensiva os territórios ditos 'selvagens' em busca de mão de obra para efetivar seus planos de dominação econômica e territorial.

O pensador camaronês Achille Mbembe é quem apresenta 0 conceito de 'necropolítica', a partir de um deslocamento teórico com base nos estudos de Michel Foucault e sua biopolítica. É necessário ressaltar que a 'necropolítica', como apontada por Achille Mbembe, tem início com o projeto colonial europeu e estende-se até os dias de hoje nos espaços de guerra e luta contemporâneos. Aqui serão explorados os pontos onde o autor verifica as práticas de poder 'necropolítico' durante o processo de escravização, porém não ignorando sua continuidade que ultrapassa séculos e territórios.

Nesse desdobramento conceitual, Mbembe afirma que os horrores orquestrados pelos regimes totalitários no século $X X$ tiveram como precedente a experiência colonial de expansão - territorial e comercial europeia ao redor do mundo, que dependia especialmente da exploração de corpos de indivíduos, e até mesmo de sociedades inteiras provenientes do continente africano em suas diásporas.

Nesta tentativa de dissolução do eixo gravitacional imposto por um pensamento eurocêntrico, Mbembe toma as experiências que ocorreram fora do continente europeu como o ponto de partida para entender as relações de poder onde a eliminação do 'outro' caracteriza a essência da soberania. Ao iniciar o texto onde dedica-se exclusivamente a essas questões o autor escreve, 
Este ensaio pressupõe que a expressão máxima da soberania reside, em grande medida, no poder e na capacidade de ditar quem pode viver e quem deve morrer. Por isso, matar ou deixar viver constituem os limites da soberania, seus atributos fundamentais. Ser soberano é exercer controle sobre a mortalidade e definir a vida como a implantação e manifestação do poder.

(MBEMBE, 2018, p.5)

A necropolítica seria então uma relação de poder onde a morte ocuparia um lugar central. Assim como na ideia de 'biopolítica', teorizado por Foucault, é o exercício do 'cálculo' e a utilização de dispositivos que produzem o controle soberano, porém não é mais a vida o alvo preferencial das estratégias de disciplina e regulamentação dos corpos e das populações. Portanto, o pensamento de Mbembe não é uma antítese da 'biopolítica' de Foucault, porém demonstra-se como um desdobramento, em vias de uma complementação.

O controle sobre a vida, de modo disciplinar e regulamentador, foi o alvo dos estudos de Michel Foucault, que dedicou parte de sua produção à pesquisa dos mecanismos e técnicas de poder encontrados na modernidade. Para Foucault, existe uma mudança na forma como o poder moderno exerce seu poder sobre os sujeitos, essa alteração é definida pelo conceito de 'biopolítica'.

Essa transformação só pôde ser alcançada devido ao fenômeno do 'cálculo sobre a vida', que começa a fazer parte dos esforços para otimizar o seu controle, tornando-se um dos elementos fundamentais para compreender os seus processos de ação. Em suas próprias palavras o filósofo nos diz que

Parece-me que um dos fenômenos fundamentais do século XIX foi, é o que se poderia denominar a assunção da vida pelo poder: se vocês preferirem, uma tomada de poder sobre o homem enquanto ser vivo, uma espécie de estatização do biológico ou, pelo menos, uma certa inclinação que conduz ao que se poderia chamar de estatização do biológico.

(FOUCAULT, 2005, p. 287)

Essa modificação seria responsável pela transição do poder soberano, que se traduziria como o "direito de fazer morrer ou de deixar viver" (Foucault, 2005, p. 286) para um novo método. Essa mudança seria não a substituição do estatuto anterior, mas sim uma forma de completá- 
lo acrescido de uma nova capacidade, ou como descreve em suas palavras,

(...) um poder exatamente inverso: poder de 'fazer' viver e de 'deixar' morrer. O direito de soberania é, portanto, o de fazer morrer ou de deixar viver. E depois, este novo direito é que se instala: o direito de fazer viver e de deixar morrer.

(FOUCAULT, 2005, p. 287)

O que é de extrema importância para as questões aqui levantadas é a localização da pesquisa de Foucault. Seus esforços estão voltados para a identificação de tais transformações no nível dos mecanismos, nas técnicas e tecnologias de poder, que nos séculos XVII e XVIII empenhavam-se na dominação do corpo, em uma esfera individual. Separar, alinhar, serializar, vigiar, organizar, estes eram os objetivos desse método disciplinador, que tinha na visibilidade do corpo a sua principal articulação. Sobre esse estágio de controle individual, Foucault afirma que tais procedimentos,

Eram igualmente técnicas de racionalização e de economia estrita de um poder que devia se exercer, da maneira menos onerosa possível, mediante todo um sistema de vigilância, de hierarquias, de inspeções, de escrituração, de relatório: toda essa tecnologia, que podemos chamar de tecnologia disciplinar do trabalho. Ela se instala já no final do século XVII e no decorrer do século XVIII.

(FOUCAULT, 2005, p. 287)

Já na metade do século XVIII, o autor identifica o surgimento de algo novo. Uma nova tecnologia de poder que age não na exclusão da anterior, mas que amalgama os seus processos, modificando-os parcialmente e, utilizando sua efetividade, consegue alargar suas capacidades. A diferença entre a técnica disciplinar e este novo método de poder está centrada, principalmente, na sua escala de atuação. Sendo assim,

(...) depois de uma primeira tomada de poder sobre o corpo que se fez consoante o modo da individualização, temos uma segunda tomada de poder que, por sua vez, não é individualizaste, mas que é massificante, se vocês quiserem, que se faz em direção não do homem-corpo, mas do homemespécie. Depois da anátomo-política do corpo humano, instaurada no decorrer do século XVIII, vemos aparecer, no fim do mesmo século, algo que já não é uma anátomo-política do corpo humano, mas que eu chamaria de 'biopolítica' da espécie humana.

(FOUCAULT, 2005, p.289) 
A partir desses novos saberes, a biopolítica permite que a soberania amplie seu raio de atuação, passando a concentrar-se em fenômenos populacionais, como a natalidade, a mortalidade e a longevidade, ou seja, ações coletivas que manifestam-se em série e que podem ser aferidas através de estimativas, estatísticas e medições globais $^{20}$. Todas essas modificações colocam a biopolítica

(...) aquém, portanto, do grande poder absoluto, dramático, sombrio que era o poder da soberania, e que consistia em poder fazer morrer, eis que aparece agora, com essa tecnologia do biopoder, com essa tecnologia do poder sobre a 'população' enquanto tal, sobre o homem enquanto ser vivo, um poder contínuo, científico, que é o poder de 'fazer viver'. A soberania fazia morrer e deixava viver. $E$ eis que agora aparece um poder que eu chamaria de regulamentação e que consiste, ao contrário, em fazer viver e deixar morrer.

(FOUCAULT, 2005, p.294)

Visto que a abordagem dos estudos de Foucault localiza-se nas técnicas com que cada forma de poder age sobre o seu alvo, é possível encontrar em sua elaboração uma distinção muito importante entre as tecnologias disciplinares e regulamentadoras. Essa diferenciação é fundamental para a compreensão dos métodos acionados na aplicação dos mecanismos de poder biopolíticos. Sobre essa o autor diz,

\begin{abstract}
Eu gostaria agora de retomar a comparação entre a tecnologia regulamentadora da vida e a tecnologia disciplinar do corpo de que eu Ihes falava agora há pouco. Temos portanto, desde o século XVIII (ou em todo caso desde o fim do século XVIII), duas tecnologias de poder que são introduzidas com certa defasagem cronológica e que são sobrepostas. Uma técnica que é, pois, disciplinar: é centrada no corpo, produz efeitos individualizantes, manipula o corpo como foco de forças que é preciso tornar úteis e dóceis ao mesmo tempo. $\mathrm{E}$, de outro lado, temos uma tecnologia que, por sua vez, e centrada não no corpo, mas na vida; uma tecnologia que agrupa os efeitos de massas próprios de uma população, que procura controlar a série de eventos fortuitos que podem ocorrer numa massa viva; uma tecnologia que procura controlar (eventualmente modificar) a probabilidade desses eventos, em todo caso em compensar seus efeitos. É uma tecnologia que visa portanto não o treinamento individual, mas pelo equilíbrio global, algo como uma homeostase: a segurança do conjunto em relação aos seus perigos internos.
\end{abstract}

(FOUCAULT, 2005, p.297)

\footnotetext{
20 "Eu thes assinalo aqui, simplesmente, alguns dos pontos a partir dos quais se constituiu essa biopolítica, algumas de suas práticas e as primeira das suas áreas de intervenção, de saber e de poder ao mesmo tempo: é de natalidade, da morbidade, das incapacidade biológicas diversas, dos efeitos do meio, é disso tudo que a biopolítica vai extrair seu saber e definir o campo de intervenção de seu poder." (FOUCAULT, 2005, p.292)
} 
$\mathrm{Na}$ biopolítica as tecnologias regulamentadoras e disciplinadoras trabalham em conjunto. Foucault atribui essa capacidade de ação pelo fato de que ambas não ocupam o mesmo nível, são escalas diferentes de atuação. Como exemplo desse processo de ação conjunta, o autor apresenta a cidade operária, apontando que:

A cidade operária, tal como existe no século XIX, o que é? Vêse muito bem como ela articula, de certo modo perpendicularmente, mecanismos disciplinares de controle sobre o corpo, sobre os corpos, por sua quadrícula, pelo recorte mesmo da cidade, pela localização das famílias (cada uma numa casa) e dos indivíduos (cada um num cômodo). Recorte, pôr indivíduos em visibilidade, normalização dos comportamentos, espécie de controle policial espontâneo que se exerce assim pela própria disposição espacial da cidade: toda uma série de mecanismos disciplinares que é fácil encontrar na cidade operária. E depois vocês têm toda uma série de mecanismos que são, ao contrário, mecanismos regulamentadores, que incidem sobre a população enquanto tal e que permitem, que induzem comportamentos de poupança, por exemplo, que são vinculados ao habitat, à locação do habitat e, eventualmente, à sua compra. Sistemas de segurosaúde ou de seguro-velhice; regras de higiene que garantem a longevidade ótima da população; pressões que a própria organização da cidade exerce sobre a sexualidade, portanto sobre a procriação; as pressões que se exercem sobre a higiene das famílias; os cuidados dispensados às crianças; a escolaridade etc. Logo, vocês têm mecanismos disciplinares e mecanismos regulamentadores.

(FOUCAULT, 2005, p.300)

Aqui temos um ponto de contato fundamental entre o pensamento de Foucault e a discussão sobre o Valongo que já foi realizada até o momento. A cidade operária, que é calculada e planejada, tem sua disposição espacial organizada para melhor proveito da população, baseando-se na utilização da técnica de ordenamento urbano e espacial para a criação de um grande meio de efetivação de mecanismos disciplinares e regulamentadores. $O$ mesmo parece acontecer com o mercado do Valongo, visto que a sua constituição espacial dava-se na forma de um conjunto de espaços ordenadamente concebidos que, mesmo possuindo escalas de atuação individuais e coletivas, conectavam-se formando uma grande rede.

Nos capítulos anteriores ficou evidente o fato de que as ações que acarretaram na constituição espacial do Valongo foram ficando cada vez mais complexas com o passar do tempo, evidenciando uma presença 
cada vez maior do Estado, dos comerciantes envolvidos no tráfico negreiro e dos habitantes livres que participavam das decisões políticas e sociais. As inúmeras leis e resoluções que foram criadas para otimizar as atividades do comércio escravista, bem como as diferentes técnicas de comercialização encontradas no Valongo caracterizam uma ação calculada e programática aos quais os negro-africanos eram expostos no interior do mercado. Desde os armazéns, com suas técnicas de disciplina e domesticação dos escravizados até as legislações e normativas dos órgãos dirigentes serviam para efetivação desse modo de controle. Michel Foucault, ao usar o exemplo da cidade operária, nos mostra que esses mecanismos de poder também se manifestam na materialidade do espaço urbano construído.

No entanto, existe uma característica na elaboração de Foucault que dificulta a utilização de suas teorias de forma tão direta quando buscamos aplica-las à compreensão do espaço colonial e a experiência do corpo negro-africano escravizado inserido nele, como no caso do mercado do Valongo. Essa dificuldade refere-se ao fato de que os diagramas de poder, a partir do acionamento dos dispositivos 'biopolíticos', têm como objetivo "fazer viver e deixar morrer", em outras palavras, a vida e o cálculo sobre ela são os alvos do poder a partir dessa perspectiva.

Mesmo quando o direito de matar é evocado, como no exemplo do 'racismo de Estado', a ideia de 'eliminação do outro' está ligada ao fortalecimento de uma vida em detrimento da outra. O racismo para Foucault vai apresentar duas interpretações:

\footnotetext{
"É primeiro, o meio de introduzir, afinal nesse domínio da vida de que o poder se incumbiu, um corte: o corte entre o que deve viver e o que deve morrer (...)

[E logo em seguida]

De outro lado, o racismo terá sua segunda função: terá como papel permitir uma relação positiva, se vocês quiserem, do tipo: 'quanto mais você matar, mais você fará morrer', ou 'quanto mais você deixar morrer, mais, por isso mesmo, você viverá'." (Foucault, p.305)
}

Porém, o sistema escravista tinha como alvo a morte do cativo. 
Assim sendo, recorreremos ao pensamento de Achille Mbembe que, como já dito anteriormente, articula as ideias de Michel Foucault com os fenômenos da colonização e da escravização, apresentando o conceito de necropolítica como o resultado deste exercício teórico. Nesta nova perspectiva, produz-se um direcionamento do olhar que nos ajuda a vislumbrar como a 'morte' torna-se o alvo do controle e do poder que determinava as condições de existência dos negro-africanos escravizados no período colonial.

Dentro os inúmeros movimentos de reposicionamento histórico propostos pelo autor camaronês, um dos mais relevantes para o presente debate encontra-se na afirmação de que o regime totalitário imposto pelo nazismo teve como precedente histórico a colonização e o sistema escravista. $\mathrm{Na}$ ação colonial europeia podem ser visivelmente identificadas a fusão entre a lógica de criação ficcional de um inimigo, o estabelecimento do estado de exceção como norma e a instrumentalização generalizada da existência humana levando a uma destruição material de corpos e populações inteiras julgadas como supérfluas ou indesejadas, visto isso,

“(...) qualquer relato histórico do surgimento do terror moderno precisa tratar da escravidão, que pode ser considerada uma das primeiras instâncias da experimentação biopolítica."

(MBEMBE, 2016. p. 130)

Em sua teoria, Foucault (2005) coloca o Estado Nazista como "o mais completo exemplo de um Estado exercendo o direito de matar." Essa completude configura-se na presença da morte em três estratos, o racismo, o assassinato e o suicídio. Como vemos a seguir,

De sorte que se pode dizer isto: o Estado nazista tornou absolutamente co-extensivos o campo de uma vida que ele organiza, protege, garante, cultiva biologicamente ao mesmo tempo, o direito soberano de matar quem quer que seja - não só os outros, mas os seus próprios. Houve, entre os nazistas, uma coincidência de um biopoder generalizado com uma ditadura a um só tempo absoluta e retransmitida através de todo o corpo social pela formidável junção do direito de matar e da exposição à morte. Temos um Estado absolutamente racista, um Estado absolutamente assassino e um Estado absolutamente suicida. Estado racista, Estado assassino, Estado suicida.

(FOUCAULT, 2005, p.311) 
O que Mbembe afirma é que a Europa já realizava esse tipo de ação racista, assassina e suicida, em sua completude, muito antes do dito 'paroxismo do jogo entre o direito soberano de matar e os mecanismos do biopoder' (Foucault, 2005, p.312) nazista. Mbembe (2016) reitera que o que encontramos no Estado Nazi "(...) são as extensões dos métodos anteriormente reservados aos 'selvagens' pelos povos 'civilizados' da Europa." (Mbembe, 2016, p.132) Assim sendo, toda a história do terror do Estado moderno, como já mencionado, antes de encontrar seu auge na "solução final" e nos horrores vividos nos campos de concentração, havia se manifestado com plena eficiência nos espaços coloniais e o complexo do Valongo pode ser um exemplo disso

Se a cidade operária, apresentada por Foucault, fundia disciplina e regulamentação para controlar a vida da população, os mecanismos disciplinares e regulamentadores aparecem no espaço colonial necropolítico como uma maneira de relegar o escravizado a condição de 'morto-vivo' (Mbembe, 2012). Essa diferença é crucial para que se possam ficar destacadas as particularidades de cada pensamento e a relevância de ambas as abordagens. A eficiência do espaço colonial é garantida graças ao, já citado, processo de transformação do escravizado em uma 'sombra personificada'. Este novo estatuto tornava possível a terceirização da sua existência a um 'outro', sendo fundamental lembrar que,

(...) como estrutura político-jurídica, a fazenda [plantation] é o espaço em que o escravo pertence a um mestre. Não é uma comunidade porque, por definição, implicaria o exercício do poder de expressão e pensamento.

(MBEMBE, 2016, p.131)

Como podemos perceber, o espaço colonial, aqui exemplificado pelo autor como a fazenda (plantation), é o lugar onde acontece a desumanização ao qual o escravizado precisa ser submetido para que se garanta a total dominação do seu 'senhor'. É apenas na redução do seu ser em força de trabalho que é permitida a sua inclusão na sociedade, e essa necessidade de força laboral é a única justificativa para que o escravizado seja mantido vivo. Aqui identificamos uma particularidade na 
ideia de morte e na forma como ela é acionada por Mbembe na necropolítica.

Sendo a escravização colonial o momento onde a população de todo um continente foi identificada como 'o inimigo' e 'o corpo' passível de eliminação em que dada sua função como força laboral, nenhuma outra dimensão da sua existência valia ser considerada, o negro-africano estava condenado a uma 'morte social' (Mbembe, 2018, p.27).

Dentro dessa dimensão social da morte podemos incluir os esforços intelectuais, anteriormente citados, responsáveis por produzir uma ficção de soberania racial do branco-europeu com relação ao negroafricano que, através de um exercício de intensa produção fantástica, construiu um mundo onde a raça passou a definir características morais, éticas e estéticas. Esse processo de construção de discurso 'sobre' o negro-africano, que ocorreu até o século XVIII, Achille Mbembe (2014) chama de um 'primeiro momento da razão negra', que produziu discursos racistas em diversas áreas da existência humana servindo para legitimar práticas de segregação que podemos sentir até hoje. Nesse movimento o branco-europeu construiu a ideia de 'Humanidade' que a cada passo dado em direção ao 'Universal' mais distanciava-se do homem negroafricano, que findou como prisioneiro de sua própria pele e assim já se encontrava excluído de qualquer noção de ser-humano utilizada para fundar as bases do mundo moderno.

A segunda dimensão da morte era a destruição física do corpo do escravizado. Essa era a decisão extrema a ser tomada - mesmo quando era a primeira - não por levar em consideração a eliminação da vida do cativo, mas sim porque o seu descarte significava a perda de uma fonte de renda. A morte física de um escravizado, nesse contexto, era justamente o índice da insuficiência de todos os mecanismos de controle da soberania e a impossibilidade de retirar qualquer proveito da existência do corpo que fosse eliminado (Mbembe, 2014, p.26).

Ambas as experiências de morte pensadas por Mbembe são levadas a cabo através da violência. Enquanto a Europa concluía seu plano de elevar-se como a alta sociedade do planeta Terra, a violência foi sendo operada de forma desmedida nos territórios além-mar. Era essa 
violência que sustentava o projeto de civilidade europeu, como nos aponta Mbembe (2017),

Foi graças ao dinheiro acumulado pelos plantadores das Índias Ocidentais que a Inglaterra do século XVIII pôde financiar a cultura emergente do gosto, as galerias de arte e os cafés, lugares por excelência de aprendizagem da civilidade (...) Como a civilidade e o consumo de produtos de luxo vêm a par, o café, o açúcar e as especiarias tornaram-se ingredientes necessários à vida do homem civilizado.

(MBEMBE, 2017, p.36)

O que fica evidente é que as terras conquistadas no período colonial eram indispensáveis para a manutenção da 'civilização de costumes', onde a sociedade ascendia aos mais altos padrões de desenvolvimento econômico e intelectual, terceirizando a barbárie para os territórios habitados pelos 'selvagens'. Por essas vias sinuosas dá-se a construção do 'mundo colonial' separado pelas fronteiras raciais, onde o negro-africano é alçado ao posto de inimigo (visto que nem sequer detém uma humanidade acabada) e a sua eliminação é legitimada pelo discurso da soberania.

Este 'mundo colonial' era pensado e construído para garantir a tranquilidade do soberano, que significava a total subserviência do escravizado. Para isso, os espaços precisavam ser dominados através de técnicas que promovessem não só a conquista territorial, mas também o controle sobre o mesmo. Se por um lado, no contexto colonial, a necropolítica era o sistema de poder que manifestava nos corpos de negro-africanos a sua condição de 'morto-vivo' através da violência e da morte, também exigia a criação de aparelhos próprios para operar os seus programas de disciplina e regulamentação.

Seria possível citar uma imensa lista de técnicas e práticas de tortura que foram desenvolvidas dentro desse universo para marcar a carne e a mente, porém era na criação de arranjos espaciais específicos às suas necessidades que o necropoder conseguiu alargar sua ação assassina a níveis genocidas. Achille Mbembe (2018) já aponta esse caminho quando nos diz que,

A 'ocupação colonial' em si era uma questão de apreensão, demarcação e afirmação do controle físico e geográfico inscrever sobre o terreno um novo conjunto de relações sociais e espaciais. Essa inscrição de novas relações espaciais 
('territorialização') foi, enfim, equivalente à produção de fronteiras e hierarquias, zonas e enclaves; a subversão dos regimes de propriedade existentes; a classificação das pessoas de acordo com diferentes categorias; extração de recursos e, finalmente, a produção de uma ampla reserva de imaginários culturais.

(MBEMBE, 2018, p.38)

A divisão das pessoas por categorias e a hierarquização dos espaços, também favoreceu a instituição de direitos diferentes para cada categoria de pessoas inseridas no mesmo espaço. A ação espacial, no contexto colonial, era o próprio exercício da soberania. Ainda recorrendo a Mbembe podemos afirmar que:

"O espaço era, portanto, a matéria-prima da soberania e da
violência que ela carregava consigo. Soberania significa
ocupação, e ocupação significa relegar ao colonizado a uma
terceira zona, entre o estatuto de sujeito e objeto" (Mbembe,
2018, p.39).

A ação colonial, exigiu a criação de espaços específicos para operar sua ação violenta de dominação. O 'mundo colonial' era o lugar onde a fronteira entre o espaço do colonizador e do colonizado era visível e materialmente delimitada, como já dito no primeiro capítulo. Era possível tocar o limite onde começava a zona do 'ser' e terminava a do 'não-ser' (Fanon, 2008, p.28). Esse mundo maniqueísta, onde a divisão entre 'bem e mal' eram tangíveis e possuíam uma materialidade própria, demonstra que o pensamento sobre o espaço recebia uma função assassina ao ser conjugado com os interesses do poder necropolítico, passando a servir como meio de criação de aparelhos destinados a reproduzir programações genocidas. É possível afirmar, dando mais um passo na investigação aqui proposta, que não estamos mais falando de uma arquitetura, mas sim de uma necroarquitetura.

Se retornarmos aos processos que envolveram a concepção do espaço urbano do Valongo, torna-se perceptível na trajetória com que o 'mercado' se transforma em um 'complexo', que a necessidade de criação de novos equipamentos dentro da estrutura do Valongo era ditada pela necessidade de aperfeiçoamento do seu potencial de produção, distribuição e descarte de negro-africanos. Esses espaços, antes de serem a manifestação de um estilo arquitetônico ou elementos 
específicos que identificam as construções a uma categoria histórica da arquitetura eram a expressão arquitetônica do necropoder.

O Valongo manifestava-se espacialmente como a materialização de uma forma de controle de corpos e mentes de negro-africanos transformados em escravizados, que tinha como objetivo a sua total eliminação simbólica e/ou física. O que é possível identificar nas estruturas que nascem dentro desta mesma lógica é que a sua existência implica o exercício da violência como norma, estabelecendo um 'estado de exceção permanente', que do contrário do 'campo biopolítico', não estava lidando com a 'vida nua', mas sim com a 'morte-em-vida', categoria que por si só já expressa a condição de 'morte reiterada na vida' ao qual era subjugada toda a populança negro-africana (Mbembe, 2018).

Por agora, vamos nos valer dessa explicação para seguir com nossa reflexão. O complexo comercial do Valongo pode ser um exemplo de necroarquitetura, ou seja, era a expressão material dos interesses necropolíticos que o sustentavam. Os espaços funcionavam em interface visando exercer o máximo do seu potencial assassino, agindo na vida de milhares de corpos de homens e mulheres, que deveriam se resumir em uma forma de existência inferior e que por essa razão poderia ser explorada e eliminada a depender da vontade do seu soberano. Talvez por isso, na teoria de Mbembe, a 'morte' venha antes da 'vida'. A experiência do negro-africano tornado o 'morto-vivo' concentra-se na dimensão de 'morte' que sua 'vida' passou a carregar após o contato com o branco-europeu na figura do colonizador.

Não que a sua existência se resuma a isso, pelo contrário, são inúmeros os casos de fuga de cativos do Valongo, bem como é possível encontrar diversos pontos de resistência e luta da população negroafricana em toda a história do período colonial, e para além dela. Desde o período da escravização até os dias de hoje os corpos e mentes colonizados e violentados produzem experiências particulares de resistência e subjetivação que marcam as suas sobrevivências ao longo dos séculos, porém todas as 'mortes' que foram operadas até que um sopro de vida pudesse ser dado precisam ser lembradas e respeitadas. 
Como constelações que insistem em brilhar em meio a grande noite que ainda não se findou em alguns pedaços do céu.

\subsection{Materialidades necroarquitetônicas no Valongo}

É necessário reiterar: a 'ocupação colonial' produziu espaços voltados para a morte, impulsionados pela violação do corpo e da mente dos escravizados. O que será investigado a partir desse dado é como o complexo comercial do Valongo conecta-se a esse processo. Inicialmente, o que pode ser afirmado é que antes mesmo de chegar ao espaço privado da fazenda, o cativo já era profundamente violentado para alcançar o estatuto de objeto que garantia tanto a sua sobrevivência como seu alto valor de mercado. O sofrimento ao qual os escravizados eram submetidos estava presente em diversos espaços, que funcionavam conjuntamente para que toda a sua condição humana fosse afetada, física e simbolicamente.

Essa ação genocida (Nascimento, 2017) no Valongo, quando compreendida na chave da necropolítica, permite observar como o funcionamento dos espaços conjugava e articulava o duplo controle, como apontado por Foucault, que se manifestava na regulamentação da vida e na disciplina do cativo, que era também o alvo de todas as ações realizadas. Todavia, o caráter violento dos processos torna a morte o objeto dos esforços empreendidos e que os distanciam das finalidades biopolíticas. Sendo assim, o complexo comercial do Valongo materializava-se como a metáfora espacial do poder violento da soberania colonial escravista, que justificava e sustentava a sua existência. Esta violência se efetivava através da intensa ação calculada e programática, onde a 'morte em vida' do cativo era produzida dentro de todas as etapas e espaços que percorria em sua estadia no mercado de almas.

Nos capítulos anteriores foram abordados momentos mais burocráticos e de aspectos ligados aos arranjos sociais e políticos da relação entre a escravização e a cidade do Rio de Janeiro, tendo como figura paradigmática o Valongo. O que será apresentado a seguir é uma análise mais aprofundada dos aspectos formais e materiais de cada 
equipamento urbano que compunha o mercado de escravos (armazéns, Cemitério dos Pretos Novos, Lazareto da Gamboa, ruas e Cais do Valongo). O olhar sobre estes espaços é importante para que possamos compreender de forma palpável como a morte se fazia matéria, tornandose um elemento físico no espaço, indo muito além de uma categoria abstrata.

\subsubsection{Armazéns}

Os armazéns de escravizados que estavam localizados no Valongo eram em sua maioria sobrados de dois pavimentos onde o comerciante e sua família habitavam o andar superior enquanto os escravizados eram mantidos no térreo. Diversos viajantes descreveram esses espaços a partir de suas visitas à região em seu período de pleno funcionamento e estes relatos nos ajudam a compreender como era a organização de tais armazéns.

Do ponto de vista formal, cabe ressaltar dois modelos de estruturação do espaço que podem ser encontrados nessas descrições. $O$ primeiro deles são os armazéns descritos como áreas abertas onde os escravizados eram mantidos em pátios no interior das edificações. Já um segundo grupo de relatos - esses mais numerosos - apresentam os armazéns como ambientes fechados, verdadeiros depósitos, em que os cativos ficavam acondicionados até o momento da venda.

Seja como fosse a estrutura espacial da edificação, um elemento é comum em todas as narrativas, os comerciantes não proporcionavam conforto para a recuperação dos recém-chegados (Karasch, 2000, p.77). Como podemos ver nas palavras de Maria Graham (1956), que visitou o Valongo no primeiro dia do mês de maio no ano de 1823 e registrou a seguinte cena:

Vi hoje o Val Longo [Valongo]. É o mercado de escravos do Rio. Quase todas as casas desta longuíssima rua são um depósito de escravos. Passando pelas suas portas à noite, vi na maior parte delas bancos colocados rente às paredes, nos quais filas de jovens criaturas estavam sentadas, com as cabeças raspadas, os corpos macilentos, tendo na pele sinais de sarna recente. Em alguns lugares as pobres criaturas jazem sobre tapetes, evidentemente muito fracos para sentarem-se. Em uma casa as portas estavam fechadas até meia altura e um grupo de rapazes e moças, que não pareciam ter mais de 
quinze anos, e alguns muito menos, debruçavam-se sobre a meia porta e olhavam a rua com faces curiosas. Eram evidentemente negros bem novos.

(GRAHAM, 1956, p.254)

Através do relato de Graham é possível acessar algumas características dos espaços que eram utilizados como armazéns de cativos. Primeiramente é interessante o fato de que, conforme descrito, 'quase todas as casas' que estavam localizadas no Valongo eram depósitos de negro-africanos, esse dado fornece uma dimensão da intensa atividade comercial da região. Outro ponto muito importante é a forma como o ambiente no interior dos armazéns era organizado. A presença de 'bancos colocados rentes às paredes' é também uma imagem corrente em outros relatos, que deixa evidente a existência de uma lógica de ordenamento dos cativos como mercadorias expostas. Desse modo, era muito comum que os escravizados fossem dispostos de maneira a atender a conveniência dos compradores, dividindo-se por categorias como idade, sexo e nacionalidade. Ainda dentro desta divisão geral o espaço era ordenado seguindo outras determinações como por exemplo,

Quando organizados por idade, os menos valiosos, isto é, os mais velhos, entre trinta e quarenta anos, sentavam-se na fileira de trás; os mais qualificados, entre quinta e vinte anos, ocupavam assentos do meio; as crianças ficavam nos assentos mais baixos ou no chão. Quando organizados por sexo, os homens ficavam nos bancos dispostos ao longo das paredes; as mulheres acocoravam-se no chão e as crianças de ambos os sexos sentavam-se na frente.

(KARASCH, 2000, p.82)

Esse rigor na organização dos cativos era recorrente em armazéns com maiores recursos ou em negociações que ocorriam com um agendamento prévio. Os agendamentos davam-se por parte dos comerciantes, na forma de anúncios em jornais de carregamentos de pessoas recém-chegadas do continente africano, informando a data em que estariam prontas para serem comercializadas. Desse modo era possível que o negociante preparasse tanto os escravizados como o ambiente para criar a melhor experiência possível para seus clientes. Entre os preparativos que eram feitos dentro dos armazéns, e como bem observado por Graham, estava a raspagem dos cabelos e o tratamento 
das feridas de doenças de pele que costumeiramente assolavam os cativos.

Este processo geralmente era realizado por um outro escravizado, sendo que

\begin{abstract}
Negros de sua própria nação raspavam cabelos e barbas dos homens. Para esconder defeitos físicos e fazê-los mais jovens e de melhor aparência, os negociantes às vezes aplicavam cosméticos. Tendo em vista que os africanos estavam especialmente magros, os comerciantes cuidavam de alimentálos aumentando gradualmente a quantidade de comida, à medida que recuperavam a saúde.

(KARASCH, 2000, p.78)
\end{abstract}

Visto que o corpo de um cativo podia dar sinais de sua saúde e de suas condições físicas, as pessoas eram mantidas praticamente nuas durante todos os processos, mesmo em períodos mais frios do ano. Quando não eram expostos completamente nus, recebiam apenas um avental de tecido, que era constantemente posto de lado no momento da inspeção dos compradores, porém

(...) se estivessem morrendo ou muito doentes, os negociantes escondiam-nos dos compradores e designavam um negro ou mulato para cuidar deles. No máximo, tinham o cuidado 'médico' de um barbeiro-cirurgião negro ou de um africano especializado em curar.

(KARASCH, 2000, p.79)

Essas práticas demonstram que os armazéns não eram apenas espaços de depósito dos escravizados, como também tinham funções de manutenção e exposição da mercadoria humana que ali estava contida. Além do espaço do salão principal, era também necessário este outro lugar para a ocultação e o tratamento dos enfermos. Alguns espaços, visto essa demanda por ambientes específicos, apresentavam estruturas mais complexas que incluíam, por exemplo, cômodos para a divisão dos cativos por sexo. Porém, como observado por Graham, alguns armazéns eram mais simples e evidenciavam esta condição através de arranjos mais básicos. Esses espaços eram, em sua maioria, lojas menores em que

(...) os escravos eram dispostos mais informalmente sobre esteiras ou bancos ao longo das paredes e ficavam atentos aos feitores para obedecer a seus comandos. Se ainda não estavam divididos por idade, sexo e nacionalidade, o feitor negro ou português mandava que se organizassem quando se aproximava um comprador. 
(KARASCH, 2000, p.82)

A figura do feitor, no caso dos armazéns com estruturas menos rígidas, era o dispositivo que alterava instantemente a forma de ocupação do ambiente, acionando com seu comando um novo ordenamento dos corpos e dos elementos no interior destes espaços. Essa dimensão do feitor como um elemento preponderante no ordenamento espacial também é visível em outros relatos, como por exemplo

Em 1826, quando entrou numa loja, o viajante Temple viu 150 'seres miseráveis deitados no chão', mas assim que o negociante o viu, estalou um chicote e todos os escravos saltaram e se arrumaram em fileiras de homens, mulheres e crianças. (KARASCH, 2000, p.83)

O som do chicote, ou até mesmo a visão do feitor, eram o suficiente para disparar a programação pré-estabelecida entre os cativos e os seus soberanos. A simples menção da violência física movimentava os corpos, impondo quase que mecanicamente uma ordem já gravada nas mentes açoitadas. A palavra 'mecanicamente' aqui poderia ser substituída por 'ritualisticamente', visto que o processo de compra, davase quase que na forma de um ritual paulatinamente repetido infinitas vezes pelos corpos até que em, algum momento, fossem subtraídos do processo de venda.

Foi esse episódio o alvo da descrição do viajante Jean-Baptiste Debret, que é visto a seguir em texto e imagem (Figura 7):

É na rua do Valongo, no Rio de Janeiro, que se encontra especialmente a loja do mercador de negros, verdadeiro entreposto onde são depositados os escravos chegados da costa africana. Às vezes, pertencem a vários proprietários e são diferenciados pela cor do pedaço de pano ou sarja que os envolve; a forma de chumaço de cabelo poupado em sua cabeça inteiramente raspada.

Essa sala de venda, comumente silenciosa, está sempre infectada pelo miasma de óleo de rícino que exala dos poros enrugados desses esqueletos ambulantes, cujo olhar curioso, tímido, ou triste, lembra o interior de uma coleção de feras. Esse mercado, algumas vezes, entretanto, convertido em salão de baile, pela permissão do patrão, agora retumba os urros cadenciados de uma fila de negros girando sobre si próprios e batendo palmas para marcar o compasso; tipo de dança muito semelhante àquela dos índios do Brasil.

Os ciganos (boêmios vendedores de negros), verdadeiros traficantes de carne humana, não perdem em nada para seus confrades negociantes de cavalos; por isso, deve-se tomar a precaução de se acompanhar por um cirurgião, para escolher um negro nessas lojas, e submetê-lo às provas que devem seguir à visita de inspeção. 


\begin{abstract}
Reproduzi aqui uma cena de venda. Reconhece-se pelo arranjo da loja, a simplicidade do mobiliário de um cigano de pequena fortuna, vendedor de negros recém-chegados. Dois bancos de madeira, uma poltrona velha, uma moringa (pote para água) e o chicote (espécie de gravata de couro de cavalo) suspenso ao seu lado, formam o mobiliário de seu entreposto. Nesse momento, os negros aí depositados pertencem a dois proprietários diferentes. A diferença da cor dos panos que thes cobrem serve para distingui-los; um é amarelo e o outro vermelho escuro.
\end{abstract}

(DEBRET in BANDEIRA \& CORREIA DO LAGO, 2009, p.184)

Este relato rico em cores, cheiros e sons amplia a percepção sobre como poderia ser a experiência de um armazém de escravizados. É relevante começar pelo fato de que cativos de mais de um comerciante podiam ser vendidos no interior dos armazéns, necessitando a criação de marcadores de diferença entre as pessoas que ali estavam em exposição. Esse dado aumenta a complexidade já vista na composição interior dos armazéns, adicionado um item a mais de estruturação do uso do espaço.

Além do aspecto visual dos corpos maltratados, Debret menciona o odor do 'óleo de rícino' que era utilizado como cosmético para melhorar a aparência dos cativos. Assim como dito anteriormente, os vendedores preparavam as mercadorias com antecedência quando a venda era préagendada, como deveria ser o caso presenciado pelo viajante, e por isso o odor marcava presença de forma mais acentuada. 


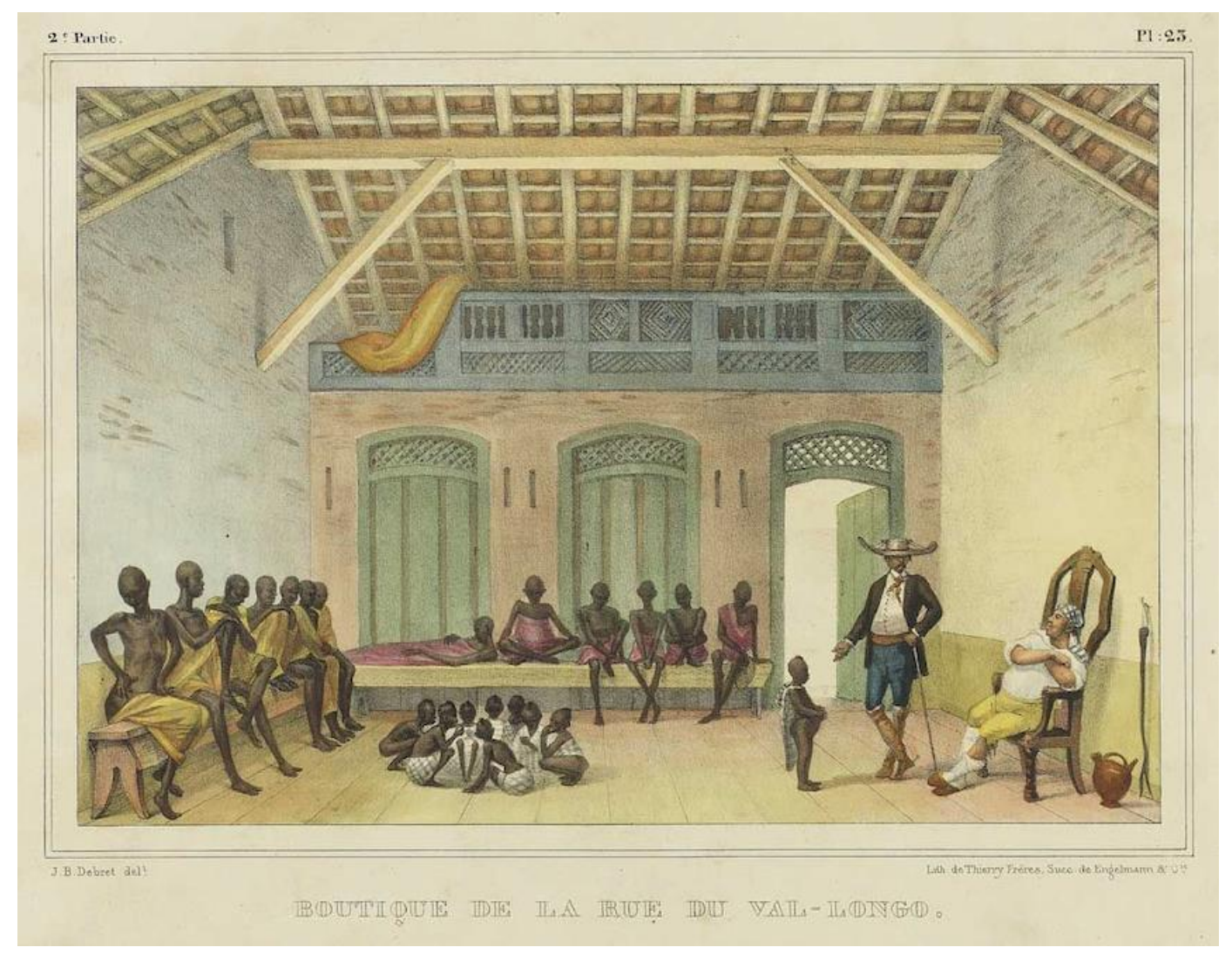

Figura 7. Mercado da Rua do Valongo - Jean-Baptiste Debret (1813-1831) Fonte: Domínio Público

O armazém visitado por Debret (entre 1816 e 1830) provavelmente se encaixaria como um estabelecimento de padrão mais simples. Essa condição se torna evidente pelo próprio 'arranjo da loja'. É curioso notar, como na visão do viajante, o espaço físico de caráter informal está conectado diretamente com a figura do 'cigano', demonstrando que este padrão de organização possuía um caráter indissociável da figura de poder do negociante no interior do ambiente e que este, por sua vez, visivelmente ocupa um lugar diferente de todos na cena.

A descrição do 'mobiliário' aqui é um fator que também salta aos olhos, uma vez que 'bancos de madeira, poltrona velha e moringa de água' figuram no mesmo conjunto que o 'chicote'. Esta particularidade torna perceptível como a violência era tratada de forma equivalente a outros elementos que integram o espaço, sem causar com isso qualquer distúrbio ou deslocamento. Era pelo movimento do chicote que os corpos esqueléticos entendiam que deviam organizar-se no espaço, reconfigurando seu interior e fazendo aparecer um novo arranjo. 
Até atividades que pareciam lúdicas, como a dança e a música citadas por Debret tinham uma finalidade comercial e meios violentos de efetivação. Esta movimentação fazia parte das estratégias utilizadas pelos negociantes visto que,

A fim de convencer os compradores de que os escravos não estavam deprimidos, os negociantes davam-lhes estimulantes para evitar a 'preguiça' e a depressão (...) Um segundo remédio para a nostalgia era 'estimular' os africanos a dançar e cantar a música de suas terras natais (...) Se alguns escravos se recusassem a tomar parte, então um feitor forçava-os a dançar, porque acreditavam que a falta de movimento estimularia a nostalgia e assim diminuiria os lucros. Além disso, exigia-se com frequência que os africanos dançassem 'de maneira alegre' durante seu exame físico, a fim de convencer os compradores de saúde excelente. Se expressassem seus verdadeiros sentimentos ou apatia e depressão eram açoitados.

(KARASCH, 2000, p.80)

Essa preocupação em demonstrar os corpos dos cativos com um aspecto saudável era também um fator decisivo para uma outra atividade de grande importância na dinâmica do armazém: a alimentação. Para que os negro-africanos fossem atraídos pela comida era comum que os cozinheiros (também escravizados) preparassem os pratos seguindo padrões de suas origens, sendo que

\footnotetext{
Os dois mais comuns eram o pirão de farinha de mandioca e o angu de fubá, encontrado também em Angola. Além desses pratos básicos, os escravos recebiam um pouco de proteína animal ou vegetal na forma de carne-seca, toucinho e feijãopreto. A fim de combater o mal-de-Luanda, ou escorbuto, os comerciantes davam-lhes também frutas frescas, como laranjas e bananas. Segundo James Holman, os escravos eram alimentados duas vezes ao dia. Por volta das nove da manhã, recebiam a primeira refeição de farinha e feijão. $A$ segunda, às três da tarde, era farinha de novo, com charque. Tabaco e rapé eram distribuídos aos de bom comportamento. (KARASCH, 2000, p.78)
}

Visto que a comida era algo imprescindível para o sustento, os armazéns necessitavam de espaços para o preparo e armazenamento de alimentos. Talvez as atividades que atendiam a alimentação dos cativos fossem realizadas no mesmo espaço utilizado para preparar a comida da família dos comerciantes, seja como fosse, esta era mais uma função que a estrutura espacial do armazém precisava comportar. A quantidade variada de atividades que compartilhavam espaços comuns (área de acondicionamento, espaço de venda, habitação do comerciante etc.) 
agregava um uso misto às edificações e impunha características flexíveis para cada um dos armazéns.

Por essa razão é difícil apontar elementos que caracterizem um modelo específico de armazém no Valongo, eram muitos os tipos de locais de comercialização, do mesmo modo como eram variadas as decisões tomadas por cada comerciante na hora de organizar o seu estabelecimento.

Era comum, por exemplo, que muitas casas de leilão e de consignação não mantivessem os cativos acondicionados em suas dependências, mantendo-os em depósitos separados onde eram alimentados e preparados para as vendas públicas (Karasch, 2000, p.85). Porém, se for preciso apontar um princípio comum entre as experiências até então levantadas, certamente podemos elencar a violência e por conseguinte suas materializações no espaço como o principal fator que unia todos esses ambientes dentro de uma mesma função: a produção e distribuição de centenas de vidas escravizadas dentro do complexo comercial do Valongo.

\subsubsection{Cemitério dos Pretos Novos}

O Cemitério dos Pretos Novos, local onde eram descartados os corpos dos cativos negro-africanos que sucumbiam durante sua estadia no Valongo, consistia em um terreno de aproximadamente 110 metros de comprimento onde eram formadas pilhas de cadáveres que, vez em quando, eram incinerados para abrir espaço aos outros vários corpos que chegavam ininterruptamente. O naturalista alemão G. W. Freireyss descreveu, em 1814, o espaço do cemitério bem como suas atividades com as seguintes palavras:

Próximo à rua Valongo está o cemitérios dos que escapam para sempre da escravidão. Em companhia do meu amigo dr. Schaeffer, que chegou aqui a bordo do russo Suvarow, em maior de 1814, em viagem ao redor do mundo, visitei este triste lugar. Na entrada daquele espaço, cercado por um muro de cerda de 50 braças em quadra, estava assentado um velho com vestes de padre, lendo um livro de rezas pelas almas dos infelizes que tinham sido arrancados da sua pátria por homens desalmados, e a uns 20 passos dele alguns pretos estavam ocupados em cobrir de terra seus patrícios mortos e, sem se darem ao trabalho de fazer uma cova, jogam apenas um pouco 
de terra sobre o cadáver, passando em seguida a sepultar outro. No meio deste espaço havia um monte de terra da qual, aqui e acolá, saíam restos de cadáveres descobertos pelas chuvas que tinham carregado a terra e ainda havia muitos cadáveres no chão que não tinham sido enterrados. Nus, estavam apenas envoltos numa esteira, amarrada por cima da cabeça e por baixo dos pés. Provavelmente procede ao seu enterramento apenas uma vez por semana e como os cadáveres facilmente se decompõem, o mau cheio é insuportável. Finalmente chegou-se a melhor compreensão, queimando de vez em quando um monte de cadáveres semidecompostos.

(FREIREYSS, 1982, p.134)

Dentro desse cenário, o único elemento construtivo descrito é um muro que demarcava os confrontantes do cemitério, delimitando o campo de atuação das atividades de sepultamento. Como visto, a imagem mais estarrecedora de todo o seu arranjo espacial era a pilha de cadáveres que se encontrava no centro do terreno. A presença dos corpos insepultos tornava a paisagem pouco agradável, além de gerar um 'mau cheiro insuportável', como dito por Freireyss.

O odor emanado pelo cemitério não incomodava apenas os visitantes que adentravam o local, era também alvo de inúmeras reclamações dos moradores do seu entorno. Tal incômodo manifestavase em inúmeras queixas oficiais registradas em nome dos moradores, principalmente a partir de 1820, onde pediam a extinção das atividades do cemitério, alegando principalmente complicações de saúde por conta das más condições com que as atividades de enterramento eram realizadas, de acordo com Pereira (2007).

Por serem inúmeras as reclamações acerca do Cemitério dos Pretos Novos, o superintendente de polícia João Ignácio da Cunha foi pessoalmente até o referido local para averiguar qual era a situação real e, com isso, constatou o que já era veementemente reforçado pelos moradores. Da sua visita, realizada em 1822, resultou um parecer que junto com o relato de Freireyss auxilia na compreensão de como se dava a estruturação do espaço do cemitério. Suas palavras nos dizem que:

O espaço que constitui o cemitério é muito pequeno para nele enterrarem tantos corpos de pretos novos, como os que ordinariamente para ali são mandados, além disso são mal enterrados porque esse trabalho está confiado a um ou dois escravos, que não se cansam de fazerem covas fundas, porém sobre tudo me admirou a nenhuma decência do lugar. Pelo lado do fundo está tudo aberto, dividido do quintal de uma 
propriedade vizinha por uma cerca de esteiras, e pelos outros dois lados com mui baixo muro de tijolos, e no meio uma pequena cruz de paus toscos mui velhos, e a terra do campo revolvida, e juncada de ossos mal queimados.

(BN. Ofício de João Inácio da Cunha Op. Cit., (doc 9). Apud: PEREIRA, 2007)

Como é possível perceber, entre o relato de 1814 e o de 1822 ocorreram algumas mudanças com relação às organizações do espaço. $\mathrm{Na}$ visita do superintendente os fundos do terreno encontrava-se todo aberto, com apenas uma cerca de esteiras separando-o do logradouro vizinho. A figura do religioso que fazia as rezas na porta do cemitério também havia sido substituída por uma simples cruz de madeira no centro do terreno onde estavam ao redor desta os 'ossos mal queimados'. O superintende continua dizendo:

Se aquele espaço de terreno, e local, era suficiente, e próprio para cemitério dos pretos novos no tempo em que foi para isso destinado, não se pode dizer, que o é presentemente, porque naquele tempo era muito menor o número de pretos novos que se introduziam nesse porto, e por consequência muito menos morriam, naquele tempo o lugar do cemitério era despovoado, hoje está rodeado de prédios habitados de moradores: não é fácil porém achar-se terreno (...) as circunstâncias (...) para servir de cemitério; porque perto não o há, e longe é um tanto incômodo para a condução dos cadáveres; e então pertencia a outra freguesia, em prejuízo dos rendimentos e (...) do atual vigário.

(BN. Ofício de João Inácio da Cunha Op. Cit., (doc 9). Apud: PEREIRA, 2007.)

O parecer de João Ignácio deixa visível que o espaço do Cemitério dos Pretos Novos recebeu um dimensionamento defasado - visto que as atividades do tráfico negreiro tiveram um impulso após 1810 - do mesmo modo que a sua localização se tornou um empecilho a partir do momento que a região deixou de ser um local isolado da cidade como antes, e estava agora 'rodeado de prédios habitados de moradores'.

O adensamento populacional na região também era obstáculo na busca por um novo terreno para o cemitério, como fica claro no parecer, porém é levantada uma questão de nível operacional que inviabilizaria a mudança: o transporte dos cadáveres entre os armazéns e o cemitério. O fluxo entre estes equipamentos já estava consolidado, alterar esse arranjo significaria mexer na conformação espacial do complexo comercial, o que poderia colocar em risco também o seu funcionamento. Assim sendo, a 
solução dada para que fosse possível melhorar as condições do local foram a sua ampliação, conforme a seguinte determinação:

Que se ordene ao vigário da freguesia da Santa Rita, a cujo distrito pertence o cemitério, que contrate o terreno que lhe fica contíguo para aumentar o cemitério existente, que o cerque todo de muro alto pelos quatro lados; que ponha pessoa capaz, que cuida em fazer enterrar bem os corpos; e finalmente que olhe para a decência, e decoro do cemitério como deve, e é de esperar do seu caráter, conhecimentos e probidade.

(BN. Ofício de João Inácio da Cunha Op. Cit., (doc 9). Apud: PEREIRA, 2007)

Se de fato as ordens de ampliação do cemitério foram atendidas não é possível afirmar, porém as reclamações dos moradores da região não cessaram com a visita feita por João Ignácio. Segundo Pereira (2007, p.88), os protestos alcançaram a Provedoria-Mor de Saúde, fazendo com que em 1824 fosse expedida uma portaria que ordenava ao provedor-mor da Saúde Francisco Manoel de Paula que averiguasse pessoalmente a situação do Cemitério dos Pretos Novos. O relato que resultou dessa averiguação acrescenta mais algumas camadas na descrição do espaço físico do cemitério, como é possível ver a seguir:

O dito cemitério no lugar em que se acha causa prejuízo à saúde, e comodidade geral dos moradores do mesmo bairro [...] pela sua situação local ser muito baixa, e receberem os vizinhos próximos imediatamente a evaporação emanada do cemitério, o que deve atacar muito a saúde dos mesmos vizinhos; por ser muito pequena a superfície do cemitério relativamente ao número de cadáveres, que ali se enterram anualmente; por ser muito baixa a situação do terreno, e cercada de casas, que embaraçam a corrente do ar necessária para conduzir as emanações do cemitério para fora da povoação; por ter o terreno muito pouca altura de terra sobre o pântano, de maneira que a pouca profundidade ficam os cadáveres mergulhados em água, sendo um terreno desta natureza não só impróprio para consumir os corpos, mas muito apto para aumentar a putrefação dos mesmos, e finalmente por se achar cercado de casas habitadas por todos os lados; sendo além disso de crer, que haja descuido do modo de fazer as sepulturas por ser isso entregue a um negro coveiro, e que portanto deve ser removido para lugar competente.

(Relatório de Francisco Manoel de Paula a João Severino Maciel da Costa, 10 de outubro de 1824, Arquivo Nacional, maço Is 4.2. Apud: RODRIGUES, Jaime. De costa a costa. p. 303. Apud: PEREIRA, 2007)

A situação não havia mudando muito entre a visita de João Ignácio e a de Francisco Manoel. A superfície do cemitério ainda era encarada como muito inferior ao necessário, mesmo com o alto índice de 
enterramentos - aproximadamente 1.019 por ano (PEREIRA, 2007, p. 87).

Além disso, o parecer do provedor-mor da Saúde nos diz que era 'muito baixa a situação do terreno' e que os cadáveres ficavam 'mergulhados em água', dada a pouca porção de terra que cobria o pântano. Esses dois fatores faziam com que o cemitério virasse um alagadiço, não sendo possível que os corpos fossem 'consumidos', tornando o local ainda mais impróprio para as atividades de sepultamento.

No que tange as disputas de interesses entre os moradores e o Estado, com relação a situação insalubre do Cemitério dos Pretos Novos, ainda houve outros episódios que acompanharam essa história. Porém, do ponto de vista espacial, a situação manteve-se a mesma até 1830 , quando

(...) em 4 de março de 1830, o cemitério foi fechado, pois nesta data se deu o último sepultamento. Um escravo novo do qual não sabemos nem nome nem origem, muito menos o navio que o transportou, foi lançado à flor da terra da mesma sorte que todos os seus antecessores. Sem nenhum outro documento localizado, nem nenhuma menção ao fato nos jornais da época, nem gazetas, nem ofícios, o Cemitério dos Pretos Novos cessou os seus trabalhos de inumação e os moradores do entorno enfim se viram livres do indesejado local de sepultamentos.

(PEREIRA, 2007, p.96)

que podemos concluir com esse panorama acerca do arranjo espacial do Cemitério dos Pretos Novos é a quase inexistência de elementos construtivos ou arquitetônicos ao longo do seu período de funcionamento, sendo unicamente notada a presença de muros ou cercas nas fronteiras com os logradouros vizinhos. Contudo, esta ausência não fazia com que o espaço deixasse de ser tão complexo como qualquer outro no território do Valongo. A pilha de corpos e o estado decadente com que eram realizados os sepultamentos não só compunham características que adjetivavam a região, como influenciava a ocupação do seu entorno. Uma das reclamações constantes dos moradores vizinhos ao cemitério era o fato de terem que manter as janelas das suas casas constantemente fechadas por conta dos odores que dali exalavam, como foi mencionado por Pereira (2007, p.83). 
Se para os habitantes a preocupação era com a sua saúde e a manutenção de seus comércios e estabelecimentos na região, provavelmente para os negro-africanos a visão de dezena de corpos constantemente incinerados, gerava outro tipo de incômodo - é preciso considerar também o fato de que, devido a localização ser próxima aos armazéns e estabelecimentos comerciais, os cadáveres empilhados certamente eram uma imagem visível do interior de inúmeros armazéns do Valongo (Karasch, 2000, p.77).

Desse modo, o Cemitério dos Pretos Novos era ele mesmo a materialização da morte dentro do complexo comercial, não só por sua função cemiterial, mas por deixar evidente o destino de qualquer um que cruzasse as barreiras, que sucumbisse aos castigos ou que desse cabo da sua própria vida.

\subsubsection{Lazareto}

De todos os equipamentos que faziam parte do complexo comercial do Valongo talvez o que tenha deixado menos rastros que nos ajudem a compreender seu ordenamento espacial, sua materialidade e as dinâmicas que estavam envolvidas nas suas operações seja o Lazareto da Gamboa. É sabido que a sua existência fez parte de uma estratégia de otimização das ações do tráfico negreiro, visto a legislação que previa a sua instalação, sendo a incorporação do Lazareto um passo significativo para a estruturação espacial do Valongo. Como abordado no capítulo anterior, a ideia era implantar um espaço para o tratamento dos cativos recém-chegados do continente africano em cada porto onde houvesse desembarques desta natureza, além disso estes estabelecimentos deveriam responder a critérios básicos de localização espacial.

No caso do Valongo, não fora encontrado nenhuma edificação que estivesse em local 'separado da cidade', e que fosse 'elevado e sadio' para cumprir as definições do Alvará de $1810^{21}$ o que tornou necessária a construção de um novo edifício seguindo tais condições. Com isso,

\footnotetext{
${ }^{21}$ (Alvará de 24 de novembro de 1813 in Coleção das Leis do Brazil do ano de 1812, Rio de Janeiro, 1890 in Soares, 2013),
} 
(...) ficou decidido que o Lazareto seria construído atrás do monte de Nossa Senhora da Saúde, custeado pelos negociantes, mas dentre eles apenas três tomaram para si esse encargo: João Gomes Valle, Jose Luiz Alves, e João Álvares de Souza Guimarães e Companhia. A planta do prédio foi aprovada por Sua Alteza Real, que o tornou público através do aviso régio de 23 de setembro de 1810, e autorizou o Provedor-Mor da Saúde a arbitrar quanto os negociantes deveriam receber por cada escravo recolhido no Lazareto.

(HONORATO, 2008, p.106)

A existência de uma planta do referido Lazareto da Gamboa é um dado importante, uma vez que suas instalações respondiam a uma demanda muito específica no que dizia respeito a seus usos e que por isso foram previamente calculadas e planificadas. O Provedor-mor de Saúde, Manoel Vieira da Silva, acompanhou diretamente os desdobramentos acerca da construção e dos subsequentes imbróglios envolvendo os negociantes menos favorecidos que não ficaram satisfeitos com as novas taxas referentes a quarentena. Acompanhar essas disputas é uma maneira frutífera de compreender como os diferentes interesses estavam manifestados no decorrer das ações, mas além disso, as tramas dessas disputas tecem outros cenários.

Um bom exemplo são os argumentos que Manoel Vieira utilizou para defender a importância das taxas cobradas no Lazareto. Dentre eles estava o fato de que as despesas com o reparo e a conservação do edifício eram muito altas, o que justificaria os valores cobrados. Aliado a essa justificativa, o Provedor-mor apontava que

(...) os proprietários do Lazareto eram responsáveis por toda a
despesa de administração que abrange tanto a edifício como
os seus utensílios, como tinas, caldeiras grandes e outros
materiais importados que não são poucos, pois além do seu
custo tem ainda as despesas de seu conserto e manutenção.
Cabe ainda aos proprietários do Lazareto as despesas com
água, lenha e azeite para luzes. Empregam-se ali também
pessoas de diferentes ministérios. (HONORATO, 2008, p.107)

Do ponto de vista da espacialidade, é possível perceber que eram utilizados vários equipamentos de grande porte no interior do edifício, demandando não só espaço físico para a sua operação, como também manutenção e cuidados constantes. Além disso, atividades administrativas de diferentes ministérios eram realizadas no Lazareto, provavelmente em espaços diferentes dos que eram destinados ao 
tratamento dos cativos. Outro ponto importante é a necessidade de uma segurança constante para controlar os africanos recém-chegados, já que

(...) a coisa mais fácil de acontecer em uma casa onde se recolhem quinhentos, oitocentos e mil escravos sem grilhões, de uma ou mais arqueações simultaneamente, sem a devida segurança, é que se extraviem ou roubem. Basta que se perca um escravo de uma arqueação que os proprietários do lazareto têm que arcar com a despesa de sua reposição, para que percam 0 interesse de recolherem no Lazareto essa arqueação. Pois se não tomassem o administrador e os guardas do Lazareto as providências necessárias para vigilância sobre as arqueações que nele se encontram especialmente à noite, podem os escravos levantarem-se, abrirem ou arrombarem as portas, fugindo e extraviando-se, isso causaria o roubo ou descaminho de muitos, e ainda podiam fugir para matar todos os empregados do Lazareto. Não são estes os fatos que ocorrerem a bordo de muitos navios?

(HONORATO, 2008, p.108)

O risco inevitável de um levante no interior do Lazareto, aliado à presença de outros funcionários ministeriais no interior do edifício tornava necessária uma constante segurança. Além de abrigar os cativos, servir de posto de trabalho para dirigentes e administradores, o edifício também era pensado para possibilitar o controle e a vigilância dos que ali estavam sendo mantidos. Ainda que seja difícil precisar o ordenamento espacial do Lazareto, é dado que ele possuía uma condição específica para cumprir a sua função. O que reforça ainda mais esse ponto de vista é o fato de que os negociantes, ao tentarem livrar-se das taxas, apontavam que os trapiches ofereciam serviços semelhantes por um preço mais baixo. Quanto a isso,

(...) o Provedor responde que, esses trapiches não eram locais apropriados para serem usados como lazareto e não tinha sido aprovados por Sua Alteza Real, pelo fato de não serem construídos com essa finalidade, não possuindo instalações nem a comodidade necessárias. Por outro lado, os donos de trapiches não tinham o conhecimento necessário para administrar um Lazareto, e ainda que alegassem ter, um trapiche não tem a segurança e nem o espaço necessário de que requer um lazareto.

(HONORATO, 2008, p.109)

Se os trapiches eram inapropriados por não terem sido construídos para essa finalidade é por que o Lazareto da Gamboa possuía um arranjo específico, que não poderia ser encontrado em outros espaços. Infelizmente não resta muito além de conjecturas que ajudam a remontar 
como era o seu ordenamento espacial, uma vez que o prédio do antigo Lazareto foi demolido. Porém, a existência de um projeto é inegável, — as plantas que nortearam a construção do espaço são provas disso - além do esforço das autoridades em salientar a especificidade do Lazareto frente a outros espaços que funcionavam como substituto. Esses fatores demonstram que a sua importância estava atrelada ao fato de ter sido concebido espacialmente dentro de uma dimensão calculada, aliando sua forma e função, que concediam a ele um aspecto singular.

\subsubsection{Cais e Ruas do Valongo}

O complexo comercial do Valongo era muito movimentado. As atividades do tráfico negreiro não atraíam somente compradores, mas também os viajantes estrangeiros e curiosos de todos os lugares, tornando o local 'parte do circuito turístico do Rio de Janeiro no século XIX' (Karasch, 2000, p.75). Esta região que no final do século XVIII era considerada periférica estava totalmente integrada a cidade já em 1820 , sendo o próprio Cais do Valongo uma referência importante, aparecendo como ponto de localização em documentos cartoriais, comprovando seu status relevante no tecido urbano e um 'marco na história da urbanização da face norte da antiga cidade' (Soares, 2013, p.21).

Sobre a estrutura do Cais em si é possível defini-lo como um

$$
\begin{aligned}
& \text { (...) calçamento de pedras talhadas de modo irregular e } \\
& \text { assentadas diretamente sobre o terreno arenoso e regularizado } \\
& \text { da Praia do Valongo. Este tipo de pavimentação é denominado } \\
& \text { no Brasil de pé de moleque e foi largamente utilizado em obras } \\
& \text { públicas dos séculos XVIII e XIX. } \\
& \text { (DOSSIE, 2017, p.32) }
\end{aligned}
$$

A estrutura do Cais parece muito simples, no seu caráter construtivo, no entanto o mesmo não é possível dizer sobre tudo o que estava ao seu redor. Este movimento de expansão ligado ao Valongo concentrou na freguesia de Santa Rita outras atividades que serviam de suporte para o comércio de escravizados, fazendo surgir na região

(...) uma complexa infraestrutura urbana. Havia o cais, onde atracavam fumaças, patachos e bergantins do tráfico africano e outras embarcações do sistema de transporte que ligava o Valongo aos outros bairros litorâneos da Corte. Havia mais construções civis, como os depósitos de armadores, de 
traficantes de escravos, de importadores de outras mercadorias e de pescadores, além dos alojamentos dos embarcadiços.

(RODRIGUES, 2000, p.367)

Mesmo com o acréscimo de outros estabelecimentos comerciais e atividades que se amalgamavam na freguesia é o comércio de escravizados que se mostra o principal polo de atração da região. O trânsito de clientes e interessados que buscavam o serviço dos armazéns de cativos fazia com que as ruas estivessem sempre movimentadas. Os anúncios de jornais são um bom exemplo deste fenômeno gerado pelo comércio de escravizados, como vemos a seguir:

\begin{abstract}
Anúncio de 12 de fevereiro de 1823, publicado no Diário do Rio de Janeiro, informava, a quem quisesse comprar, que "duas crioulinhas de 11 para 12 anos, com bons princípios de costura e mui habeis para todo serviço de huma casa (sic)" estavam à venda e que os interessados deviam procurar "no fim da praia do Valongo antes de chegar à Saúde, à rua do Prepozito, que nas segundas lojas do sobrado n. 10, se lhe dirá quem as pretende vender". (DOSSIE, 2017, p.91)
\end{abstract}

Como apresentado anteriormente, os anúncios eram utilizados pelos donos de armazéns, mas também podiam ser postados por qualquer um que possuísse um escravizado e estivesse interessado em vendê-lo. Além do movimento gerado pelos armazéns, as ruas do Valongo tinham um trânsito rotineiro de vendedores que faziam suas transações de porta em porta, visto que

\begin{abstract}
No início do século [XIX], alguns dispensavam a casa ou pátio e simplesmente acorrentavam junto um grupo de novos escravos, conduzindo-os pelas ruas e anunciando-os de porta em porta. Outros, até mesmo mulheres, levavam-nos a uma praça popular ou mercado e exibiam os escravos ao lado de animais, frutas e verduras. (...) Em 1816, Ellis escreveu que encontrava com frequência 'dois ou três jovens interessantes, levemente vestidos e com um lenço novo de algodão vermelho em torno da cabeça, sendo conduzidos pelas ruas por um vendedor de escravos que, encontrando nas diferentes casas e oficinas por onde passava, oferecia os jovens negros para venda. (KARASCH, 2000, p.81)
\end{abstract}

Este tipo de comercialização é encontrado em gravuras de viajantes como Augustus Earle, que segue abaixo, onde é possível ver o processo de venda de cativos sendo realizado na via pública. É visível também, em segundo plano, a presença de trabalhadores escravizados e da vigilância policial. 


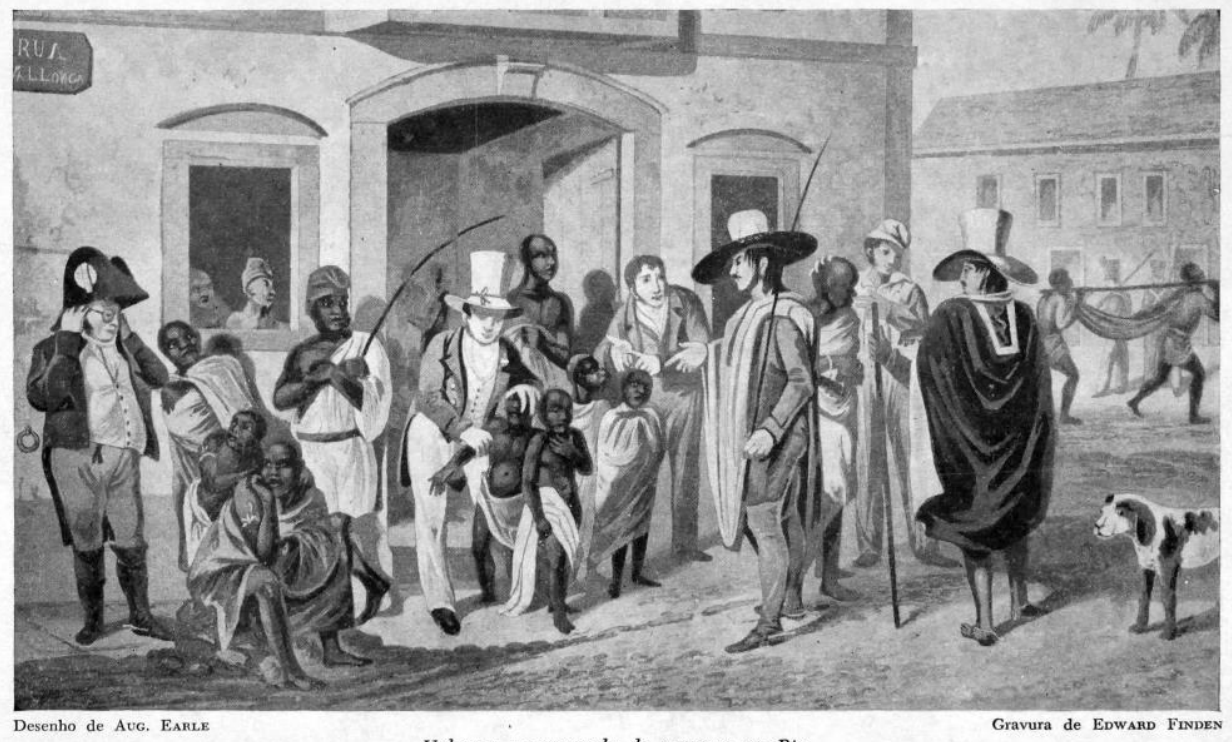

Valongo, ou mercado de escravos no Rio

Londres, publ, por Longmam \& Cia e J. Murray, 5 de abril de 182

Figura 8. Valongo, ou mercado de escravos no Rio - Edward Finden (1824)

Fonte: Domínio Público

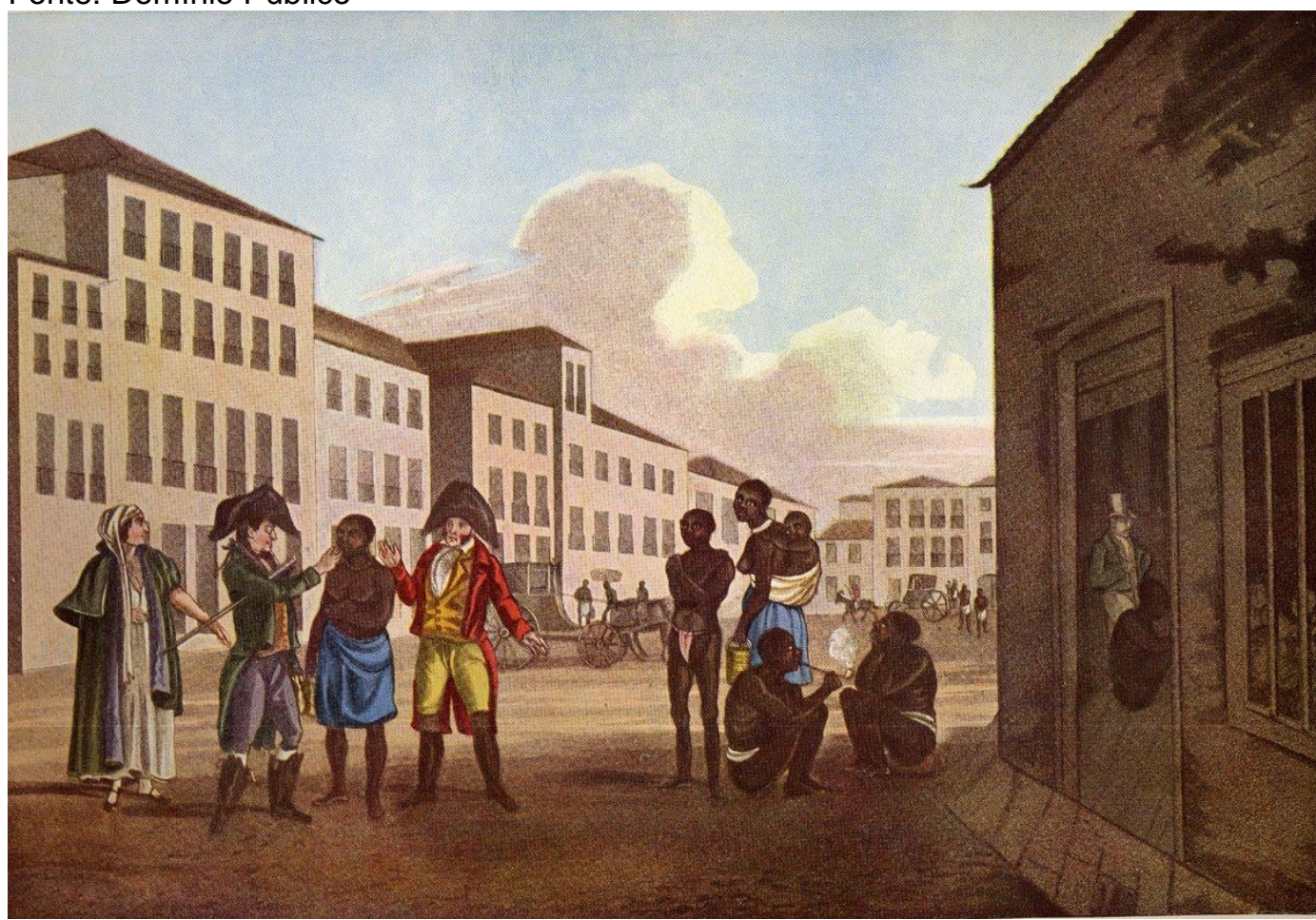

Figura 9. 0 mercado de escravos - Henry Chamberlain (1820)

Fonte: Domínio Público

Do mesmo modo, Henry Chamberlain descreve, em texto e imagem (Figura 9), esse processo de compra como uma peregrinação por parte dos compradores que,

(...) andavam de casa em casa, fazendo um minucioso exame de cada um para evitar os truques utilizados pelos comerciantes para vender escravos doentes ou com defeito 
físico, dai a importância de ouvir a opinião de um cirurgião de confiança que muitas vezes acompanhava o comprador.

(HONORATO, 2008, p.85)

É importante notar que em ambas as imagens, além das cenas de venda retratadas, estão presentes elementos que indicam movimento e trânsito no plano de fundo. Também é notável a predominância de edificações com mais de um pavimento, sendo apenas na imagem de Chamberlain visto uma casa térrea que, por sua vez, difere em seus aspectos estéticos das demais estando visivelmente deteriorada e possuindo barras nas janelas, o que também serve de índice do caráter ‘selvagem' acrescido aos cativos.

Um outro relato que traz um apontamento muito semelhante sobre a ambiência do Valongo é o de Johann Moritz Rugendas (1835), que frisa a semelhança entre o espaço dos cativos com o dos animais, além de outras descrições acerca da experiência de visitar a região:

\begin{abstract}
Da alfândega os negros são conduzidos para os mercados, verdadeiras cocheiras. Aí ficam até encontrar comprador. A maioria dessas cocheiras de escravos se acha situada no bairro do Valongo, perto da praia. Para o europeu, o espetáculo é chocante e quase insuportável. Durante o dia inteiro esses miseráveis, homens, mulheres, crianças, se mantêm sentados ou deitados perto das paredes desses imensos edifícios e misturados uns aos outros; e, fazendo bom tempo saem à rua. Seu aspecto tem algo horrível, principalmente quando não se refizeram da travessia. $O$ cheiro que se exala dessa multidão de negros é tão forte, tão desagradável, que se faz difícil permanecer na vizinhança quando ainda não se está acostumado. Os homens e mulheres andam nus, com apenas um pequeno pedaço de pano grosseiro em volta das ancas. São alimentados com farinha de mandioca, feijão e carne-seca. Não lhes faltam frutas refrescantes.

(RUGENDAS, 1979, p.175)
\end{abstract}

Ao passar pelo Valongo entre 1822 e 1825, Rugendas percebeu a mesma movimentação de cativos nas ruas, ressaltando o quão característico era o cheiro da 'multidão de negros' sendo 'tão desagradável, que se faz difícil permanecer na vizinhança quando não se está acostumado'. Considerando a forma como os cativos eram mantidos no interior dos armazéns é totalmente compreensível que o cheiro desses lugares causasse esse tipo de reação a um passante 'não acostumado'. Além dos armazéns, as águas que ficavam próximas ao Cais do Valongo eram consideradas verdadeiras 'valas fétidas', ao passo que 


\begin{abstract}
À sua direita, corria a vala de escoamento natural das águas oriundas dos morros e do interior, que desciam até o mar. À sua esquerda, foi feita uma canaleta principal, no sentido longitudinal, que drenava as águas que desciam de enxurrada pela ladeira do Livramento, também até o mar; e pelo menos uma valeta secundária, que, no sentido transversal, desaguava na canaleta principal. Um excelente caimento voltado para ambas as direções assegurava o escoamento.
\end{abstract}

(DOSSIE, 2017, p.33)

Certamente a junção destes odores com os do já citado Cemitério dos Pretos Novos deveria causar um extremo desconforto para os que não estavam habituados em transitar pela região. Além disso, é preciso considerar o grande trânsito de cadáveres e doentes, provenientes do Lazareto e dos próprios armazéns, que combinados tornavam o complexo comercial do Valongo 'uma das áreas mais insalubres da cidade', como mencionado por Karasch (2000, p.77).

Junto ao movimento das ruas e o mal cheiro, outro dado marcante na atmosfera da região eram os sons de tambores, palmas e canções africanas entoadas pelos escravizados nos armazéns. Como já salientado por Debret, o mercado algumas vezes era 'convertido em salão de baile, pela permissão do patrão'. Porém, como visto, nem sempre o que motivava a dança entre os cativos era o prazer de estar em contato com tradições que remetiam às suas terras natais, pelo contrário,

Se alguns escravos se recusassem a tomar parte [na dança],
então um feitor forçava-os a dançar, porque acreditavam que a
falta de movimento estimularia a nostalgia [nos cativos] e assim
diminuiriam os lucros. Além disso, exigia-se com frequência
que os africanos dançassem 'de modo alegre' durante seu
exame físico, a fim de convencer os compradores de sua
saúde excelente. Se expressassem seus verdadeiros
sentimentos ou apatia e depressão, eram açoitados. (KARASCH, 2000, p.80)

Em um outro relato de Freireyss também está presente a dança no interior dos armazéns, onde presenciou a 'alegria barulhenta' dos cativos, descrevendo a cena da seguinte forma:

Encontramos aí alguns centos de negros nus e raspados, diversos tanto na idade como no sexo, que formavam uma grande roda, batendo palmas com toda a força, acompanhadas com os pés e com um canto gritado e de 3 notas apenas.

Da roda saem de repente um deles, pula para o centro onde dura sobre si mesmo, movendo o corpo em todas as direções, parecendo destroncar todas as articulações, e aponta para um outro qualquer, que por sua vez pula para dentro, fazendo o mesmo que 0 anterior e assim, sem mudança nenhuma, 
continuam até serem vencidos pelo cansaço. Esta dança às vezes dura horas, com grande descontentamento dos vizinhos. (FREIREYSS, 1982, p.134)

Unindo todos esses elementos encontrados na narrativa dos viajantes, seja através de texto ou de imagens, é possível perceber que o Valongo mesmo sendo a região mais insalubre e abarcando a atividade mais infame de toda a cidade era altamente movimentado e dinâmico, repleto de cheiros, imagens e sons. Ao contrário do que pode ser imaginado, a freguesia teve um aumento no número de habitações após a transferência do mercado de escravizados, bem como obras de melhoramentos da sua infraestrutura urbana (Honorato, 2008). Contudo, é notável o quanto a presença dos armazéns, bem como das atividades ligadas ao comércio negreiro, marcava profundamente a paisagem e a ambiência do Valongo. As inúmeras sensações, as formas de organização e as funções que estes espaços desempenhavam eram elementos indissociáveis, dando à 'morte' uma forma física e geograficamente delimitada.

A experiência do Valongo demonstra que a cidade do Rio de Janeiro foi estruturada de modo a conceder espaços e tratamentos específicos para pessoas pertencentes a grupos étnicos distintos, o que gerou uma setorização dos espaços, em diversas nuances, tendo como critério principal a condição de soberania da classe branca-europeia em detrimento dos subalternos negro-africanos. Esta separação impulsionou transformações na forma da cidade, construindo física e simbolicamente os limites que determinavam a zona destinada a cada grupo, sendo o Valongo um lugar paradigmático nesta estrutura.

Como ressaltado nas análises aqui apresentadas, a materialidade e a forma do ambiente construído do mercado de escravizados estava totalmente ligada à sua função assassina, deste modo o que percebemos é a arquitetura - enquanto este conjunto de saberes e técnicas de construção espacial - sendo utilizada para fins necropolíticos, caracterizando o que é chamado aqui de necroarquitetura. 


\subsection{Necroarquitetura: uma máquina de matar}

O Mercado do Valongo, e a ideia de necroarquitetura, não são um exemplo isolado de como a arquitetura pode ser usada como ferramenta de controle. Michel Foucault já havia identificado uma 'arquitetura operativa na transformação dos indivíduos' ao produzir suas reflexões sobre o poder moderno; da mesma forma, o também francês Georges Bataille, vislumbrava na arquitetura uma 'fisionomia de personagens oficiais' que produzia um sentimento de opressão na população. Ambos os filósofos partem das suas experiências com as instituições europeias para elaborar tais concepções sobre o poder na modernidade. Porém, não teria a ação colonial, através da necroarquitetura, unido o uso da arquitetura na sua função operativa de 'transformação de indivíduos' com a capacidade de opressão simbólica da arquitetura? Não seria essa a principal característica do complexo comercial do Valongo, ser ao mesmo tempo instrumento e símbolo da morte materializada no espaço físico?

Comecemos com a perspectiva de Michel Foucault. As técnicas de planejamento espacial estão no centro das suas concepções sobre a produção de um 'sujeito útil e dócil', que era também o objetivo das técnicas de disciplina e regulamentação 'biopolíticas'. Como símbolo desse tipo de relação de poder temos a estrutura do 'Panóptico de Bentham', um modelo arquitetônico que a partir de seu arranjo espacial cria um mecanismo de visibilidade ininterrupta, impossibilitando a formação de zonas de obscuridade. Vejamos a descrição de Foucault do modelo arquitetônico 'panóptico'

(...) na periferia, uma construção em anel; no centro, uma torre;
esta possui grandes janelas que se abrem para a parte interior
do anel. A construção periférica é dividida em celas, cada uma
ocupando toda a largura da construção. Estas celas têm duas
janelas: uma abrindo-se para o interior, correspondendo às
janelas da torre; outra, dando para o exterior, permite que a luz
atravesse a cela de um lado a outro. Basta então colocar um
vigia na torre central e em cada cela trancafiar um louco, um
doente, um condenado, um operário ou um estudante.
(FOUCAULT, 1987, p.210)

No panóptico, o espaço é pensado para produzir a experiência disciplinar necessária para a docilização do corpo, ou seja, a possibilidade de vigilância intermitente inibe ações ilícitas ou que rompem com o 
padrão de normalidade instituído pelo poder soberano. Nessa estrutura, o poder desenvolve-se no interior, os ambientes são arranjados de modo a permitir a recondução dos seus efeitos, modificando e controlando comportamentos (Foucault, 1987, p.194). O controle é total, não há saída.

Retornemos à descrição de Jean-Baptiste Debret sobre 0 funcionamento de um armazém de venda de escravizados no Valongo:

\begin{abstract}
Reproduzi aqui uma cena de venda. Reconhece-se pelo arranjo da loja, a simplicidade do mobiliário de um cigano de pequena fortuna, vendedor de negros recém-chegados. Dois bancos de madeira, uma poltrona velha, uma moringa (pote para água) e o chicote (espécie de gravata de couro de cavalo) suspenso ao seu lado formam o mobiliário de seu entreposto. Nesse momento, os negros aí depositados pertencem a dois proprietários diferentes. A diferença da cor dos panos que thes cobrem serve para distingui-los; um é amarelo e o outro vermelho escuro.

(DEBRET, Jean-Baptiste apud IPHAN, Op. cit., p.89)
\end{abstract}

A vigilância era um elemento fundamental para o funcionamento do armazém de cativos. Tal faz-se presente não só na figura do próprio vendedor de escravizados e seu cliente, mas também no chicote, instrumento de tortura, que funciona como o indício da violência que instaurava o terror necessário para a efetivação da necropolítica. Eram muitos os inibidores de conduta utilizados no interior desses espaços para modificar o comportamento dos cativos. Na verdade, toda a cidade era organizada de modo a produzir a vigilância e o controle do negro-africano escravizado e, por consequência, dar a sensação de conforto e a segurança do soberano, como podemos ver em Karasch (2000. Op. cit., p.100). Vamos agora à imagem.

O que podemos alcançar com a aquarela de Debret (Figura 7) é uma dimensão muito maior do que a simples experiência de controle sendo operada no interior de um armazém do Valongo. O movimento que o olho faz ao percorrer a imagem constrói a própria narrativa que descreve a hierarquização da sociedade que se dividia entre a zona do 'não-ser' e o espaço soberano.

É possível notar o aspecto de clausura com que eram mantidos os cativos. Vemos somente uma fonte de contato com o 'fora', com o que está além das paredes e possivelmente com a própria liberdade. A porta, por onde entra a luz natural no ambiente, é o único elemento que nos 
leva para além da cena. A presença desta saída nos dá fôlego para imaginar um mundo que vá além dessa situação deplorável, mas quando encaramos o 'fora' nada podemos ver além da luz. Uma luz que ofusca e faz arder o olhar de quem é obrigada a acostumar-se com a escuridão do cárcere. A luz pode ser a liberdade, mas também a dor.

A cegueira causada pelo ofuscamento impede que identifiquemos qual é a forma do 'mundo' fora do armazém, da mesma maneira que deveria ser ainda mais incerto e difuso para qualquer cativo que atravessasse a soleira. $\mathrm{Na}$ imagem, o cativo que encontra a mão estendida do seu algoz tem também à sua frente uma ponte entre o dentro e o fora, uma possibilidade de alcançar o que está além. Mas sair do armazém dessa maneira significava deslocar-se da categoria temporária de mercadoria e tornar-se 'propriedade de alguém'.

Deixar o armazém como escravizado não era o mesmo que liberdade ou segurança, pelo contrário, significava ser inserido em novos aparelhos de controle, agora com uma nova programação de violência e morte. Debret nos dá a ver a própria noção da divisão maniqueísta do mundo colonial que, deixava evidente os limites entre o espaço habitado pelos 'selvagens' e instaurava a soberania na posição privilegiada de onde conseguia realizar o controle total. Muitas são as possibilidades que essa imagem nos apresenta, mas fiquemos com estas observações por enquanto. Partiremos agora para as concepções de Bataille.

Diferente de Foucault, George Bataille (1970) identifica na arquitetura a capacidade de expressar 'a fisionomia de personagens oficiais', ou seja, reproduzem em sua superfície o poder. São elas mesmas a cara do poder. A arquitetura, o corpo do edifício, e sua forma são a representação da soberania que ao erguerem-se no espaço passa a servir de inspiração às boas condutas e inibir o comportamento social. $A$ opressão simbólica exercida dá-se no campo do temor, que ameaça simbolicamente a vida do indivíduo. Bataille nos diz com suas próprias palavras que,

De fato, apenas o ser ideal da sociedade, aquele que ordena e proíbe com autoridade, se expressa nas composições arquitetônicas propriamente ditas. Assim, grandes monumentos se levantam como diques, contrapondo a lógica da majestade e 
da autoridade a todos os elementos turvos: é sob a forma de catedrais e palácios que a Igreja e o Estado se dirigem e impõem silêncio às multidões.

(BATAILLE, 1970, p.171)

É na dimensão simbólica que a arquitetura funciona como um elemento repressivo, na perspectiva de Bataille. A exterioridade monumental faz cessar as vozes e intimida a movimentação, garantindo ao soberano a segurança e a contenção das ondas que possam levantarse contra os seus interesses: uma forma de coerção absoluta. Isso explica, para o filósofo, os ataques que sempre são realizados a tais monumentos quando ambiciona-se atingir as estruturas de poder.

Atacar o monumento é atingir o homem, pois eles são como se o próprio homem fosse. Os espaços pensados dentro dessa lógica são os responsáveis por produzir a 'admiração e o espanto', a 'ordem e a restrição'; elementos que auxiliam a criação de 'multidões sombrias', subalternas (Bataille, 1970).

Façamos então nossa última incursão ao 'mercado de almas'. A morte, sendo o objeto principal dos esforços de controle do soberano, na necropolítica, vira também o emblema máximo de um poder que silencia definitivamente os que não estiverem devidamente inseridos nos padrões de conduta e materializa essa inibição no espaço. Retornemos ao relato viajante alemão G. W. Freireyss sobre o Cemitério dos Pretos Novos, em 1814 ,

\footnotetext{
Próximo à rua do Valongo está o cemitério dos que escapam para sempre da escravidão... na entrada daquele espaço cercado por um muro de 50 braças em quadra (...) alguns pretos estavam ocupados em cobrir de terra os seus patrícios mortos e, sem se darem ao trabalho de fazer uma cova, jogam apenas um pouco de terra sobre o cadáver, passando em seguida a sepultar outro.

No meio deste espaço havia um monte de terra da qual, aqui e acolá, saíam restos de cadáveres descobertos pela chuva que tinham carregado a terra e ainda havia muitos cadáveres no chão que não tinham sido ainda enterrados.

Nus, estavam apenas envoltos numa esteira, amarrados por cima da cabeça e por baixo dos pés. Provavelmente procedese o enterramento apenas uma vez por semana, como os cadáveres facilmente se decompõem, o mau cheiro é insuportável. Finalmente chegou-se a melhor compreensão, queima de vez em quando um monte de cadáveres semidecompostos.

(FREIREYSS, 1982, p.134)
} 
O que é nomeado por cemitério, na verdade, era um grande local de desova de corpos de negro-africanos descartados pelos armazéns e outros aparelhos do complexo comercial. A falta de dignidade com que se dava o enterramento, a visão do 'monte de cadáveres semidecompostos', 'o mau cheiro insuportável' - diversos são os elementos dados pelo relato de Freireyss que nos aproximam do que deveria ser a morte materializada em seu estado mais bruto dentro do Valongo.

Qualquer negro-africano que ultrapasse os limites ou ao menos pensasse em alguma tomada de posição contra a sua situação de cativo tinha em seu campo de visão a pilha de mortos ao qual poderia vir a fazer parte caso transgredisse as normas de conduta. Se não fosse com a visão dos cadáveres, poderia ser através do cheiro dos corpos queimando, se não fosse a partir do olfato, poderia ser ouvindo o som da carne crepitando nas fogueiras. Eram inúmeras as possibilidades de produzir a opressão através da superexposição da morte no Valongo, os arranjos espaciais eram pensados para deixar a morte na superfície, porém, nenhum deles parece ter trabalhado tão ‘à flor da terra' quanto no Cemitérios dos Pretos Novos (Pereira, 2007).

Muitos outros passos ainda podem ser dados nas trilhas abertas pelas análises aqui empreendidas, porém o que fica latente é o fato de que a necroarquitetura conjuga os dois tipos de controle, operativo e simbólico, apontados pelos autores em suas concepções. Os diversos dispositivos que compunham o Valongo estavam arranjados de modo a expor em suas estruturas físicas quais eram as restrições impostas a cada um que adentrasse por seus interiores. Seja na esfera política e social, ou na experiência sensível dos corpos no espaço, a morte era o eixo estruturador, o elemento presente em todas as esquinas e no interior de todas os edifícios em que negro-africanos eram mantidos como mercadoria ou como mão de obra escravizada. Em alguns casos estas estruturas não eram fixas e os arranjos davam-se de modo flexível afim de atender as demandas de cada comerciante ou proprietário de armazém, porém muitos espaços estavam fortemente presos ao solo, como era o caso do Lazareto e do Cemitério dos Pretos Novos. 


\section{Considerações Finais}

Silêncio.

A história que acabamos de acompanhar provoca este silêncio aterrador. Mas não é como um vazio, apenas um buraco ou uma coisa oca. De fato, a exposição extenuante a tantas mortes causa um certo torpor. Porém é preciso superar o horror. Isso também não significa que todo esse percurso tenha sido um exorcismo, como se agora estivéssemos livres dos fantasmas, já que decidimos encarar a sua face assustadora.

O silêncio é um desejo de luto.

Repassar estes momentos atrozes da história é uma tentativa de fazer com que todas as mortes operadas neste processo não tenham sido em vão. Olhar para o Valongo e suas memórias de sofrimento pode ser uma experiência de cura e emancipação a partir do momento que tais narrativas não sirvam para reproduzir estereótipos ou subalternidades, mas sim para realizar denúncias que ajudem a desmantelar as ficções racistas e os projetos genocidas que ainda estão presentes no nosso cotidiano.

Este silêncio também não presume uma quietude, muito menos uma tranquilidade. Ele é diferente do silenciamento que tenta calar as diversas vozes que gritam a plenos pulmões suas revoltas, seus clamores de justiça e reparação. Não estamos falando de mudez, ou da ausência de barulho. As covas sempre estiveram ocupadas, o fundo dos oceanos está repleto de ossadas, as prisões permanecem superlotadas. Os corpos negros continuam encadeados no poço da marginalidade, porém nunca foram completamente calados. É para que possamos ouvir estes chamados que o silêncio é tão importante.

Através deste trabalho tentamos ouvir algumas destas vozes que falam nas pedras do Cais do Valongo, hoje uma pequena janela arqueológica do que ontem era um imenso vazio de perigos e incertezas na vida de tantos que por ali passaram. E se é possível dizer que concluímos alguma coisa deste processo, certamente estamos falando 
mais de elementos que precisam ser evidenciados, não por serem desconhecidos, mas porque precisam ser reforçados.

Grande parte da história do Valongo é pública. Está nos documentos oficiais, periódicos, relatos de viajantes e na memória dos que habitam a região. Não são histórias perdidas, nem mesmo mortas. Diariamente a memória da escravização, na forma de inúmeros preconceitos e racismos, são reiterados nas vidas negras que permanecem lutando. Estamos falando de uma memória viva. Por isso o silêncio é também um desejo de vida. Vontade que a vida jorre. O sonho por uma existência que ultrapasse as barreiras que se erguem constantemente sustentadas por séculos de opressão e violências.

Como vimos em um primeiro momento, a cidade do Rio de Janeiro sempre foi palco destas violências, que se manifestavam em segregações espaciais e divisões raciais. A estratificação social do espaço da cidade estava diretamente ligada à ideia de superioridade racial que reservava para o branco-europeu o lugar privilegiado da soberania enquanto para o negro-africano, escravizado ou não, restavam os espaços do cárcere ou da paralisia social. Mesmo livre, o negro-africano estava imobilizado no interior das estruturas em que ocupava, relegado sempre a permanecer na zona do 'não-ser', condenado a preparar um banquete ao qual não era convidado a compartilhar, mesmo que provasse a sua capacidade perante os demais. Era assim nas estruturas militares, religiosas e do trabalho subalterno no comércio e nos portos. Mesmo desempenhando funções semelhantes as dos branco-europeus menos favorecidos, ainda permanecia em um lugar inferior pela sua condição étnico-social. Porém, as vozes soterradas no tempo e no espaço nos falam de um outro lado da cidade, tecendo as tramas de outra história.

Nele os escravizados se quilombavam e produziam suas próprias redes paralelas de comércio e trocas sociais. As irmandades negras, mesmo que com uma ação limitada, atuavam na conquista financeira de alforrias. As quitandeiras e os escravizados de ganho lutavam por sua emancipação e a dos que conseguiam alcançar com seu trabalho. No Valongo as casas de zungú serviam ao mesmo tempo como ponto de 
proteção e combate, favorecendo as interações sociais e culturais entre os negro-africanos de diversos lugares do Brasil e da África.

Muitas vezes os espaços de dor e de liberdade compartilhavam o mesmo ambiente, divididos por uma linha muito fina. Esta cisão deveria estar sempre visível aos olhos do escravizado que não podia cruzar as fronteiras definidas pelo soberano, visto a possibilidade de pagar com a sua própria vida o preço desta atitude.

Se estas vidas tinham nome, infelizmente não são possíveis de identificar de modo tão particular, poucos foram os que ficaram conhecidos por eles, reais ou não. Os nomes eram quase todos genéricos. Tão supérfluos, aos olhos dos soberanos, quanto os corpos que os carregavam. Marias, Franciscas, Antônios, Pedros. São palavras que nos levam a poucos lugares quando tentamos seguir o rastro destes personagens subterrâneos. Mas se milhares de mortos são anônimos alguns assassinos podem ser nomeados.

Atenção para a chamada.

Amaro Velho da Silva. Antônio da Cunha. Antônio Fernandes da Torre. Antônio Ferreira da Rocha. Antônio Gomes Barroso. Antônio Joaquim Maia. Antônio José da Costa Barbosa. Antônio S. da Rocha. Bento Antonio Muniz. Bernardo Loureiro Viana. Carlos José Moreira. Custódio de Souza Guimarães. Domingos Gonçalves de Azevedo. Fernando Carneiro Leão. Francisco Antonio de Barros. Francisco Gonçalves da Silva Campos. Francisco Joaquim Ferreira. Francisco Joaquim de Matos. Francisco José Fernandes Barbosa. Francisco José Fernandes Salazar. Francisco José Guimarães. Francisco José da Rocha. Francisco Luiz de Almeida. Francisco Pereira de Mesquita. Francisco José Xavier Dantas Moreira. Frutuoso José da Cruz. Jerônimo José de Oliveira Guimarães. João Alberto de Almeida Vidal. João Alves de Souza Guimarães. Joao Araújo Silva. João Fernandes Lopes. João Gomes Barroso. João Gomes do Vale. João Inácio Tavares. João Lopes Batista. João Luiz Figueiredo. João Mota de Almeida Vidal. João Ribeiro da Silva. João Soares de Almeida. Joaquim Antônio Jusseis. Joaquim José Cardoso Guimarães. Joaquim José da Rocha. Joaquim Ribeiro de Almeida. José Antonio Fernandes de Sá. José Domingues. José Francisco do Amaral. José Gomes Pupe Correia. José Inácio Vaz. José Luiz Alves. José Luiz da Mota. José Marcelino Gonçalves. José Pereira Guimarães. José Rodrigues Borges. Luiz Antonio Fernandes Barbosa. Luiz Souza Dias. Manoel Antonio Coelho. Manoel Caetano Pinto. Manoel Gomes. Manoel Gomes Cardoso. Manoel Gonçalves de Carvalho. Manoel Guedes Pinto. Manoel Joaquim de Azevedo. Manoel José Ribeiro de Oliveira. Manoel José da Silva. Manoel M. de Azevedo. Manoel Simões Batista. Manoel Teixeira de Carvalho. Marcos Martins. Narcizo Luiz Alves Pereira. 
Estes são apenas alguns dos comerciantes donos de armazéns no Valongo, que assinaram em 1810 um abaixo-assinado contra as novas taxas que seriam empregadas no tráfico a partir daquele período. Nomes que estão diretamente ligados ao processo de desenvolvimento do complexo comercial do Valongo. Estes não eram os únicos. E se prolongarmos nosso período de silêncio provavelmente ouviremos outros. Vindos dos monumentos em praças, dos livros de história, dos nomes das ruas e das escolas que estudamos.

Precisamos encontrar outros lugares para estes nomes nas narrativas oficiais. Como também precisamos encontrar outras formas de contar a história da cidade. Por isso percorremos o Valongo ao longo de todas estas páginas. A cidade do Rio de Janeiro possuía, no mercado de escravizados, um centro comercial ativo e extremamente importante não só para a economia do país, como do continente e, principalmente, de Portugal.

O complexo comercial do Valongo, sendo responsável por redirecionar grande parte da carga humana recebida pelo tráfico escravista mundial, sustentava as bases econômicas de grande parte dos territórios coloniais e mesmo assim não figura de forma central as narrativas históricas sobre o desenvolvimento da cidade. Esta memória indesejável tem se tornado cada vez mais inescapável.

Não conseguir escapar dos horrores suscitados pelo cais do Valongo não significa que devemos ficar presos nele. Já tivemos muitas histórias de cárcere. Basta. Precisamos descobrir novas formas de escapar das antigas prisões, produzindo os alargamentos e rompimentos necessários, gerando os reposicionamentos que vão desestabilizar os velhos centros de gravidade do mundo.

Este é convite que Achille Mbembe faz ao apresentar o conceito de necropolítica. Ao produzir seu pensamento a partir de outra experiência que não a europeia, aponta de partida a insuficiência da ideia de biopolítica para compreender o que se passou em África e nos outros espaços a partir do processo de colonização. Assim como o Valongo, a 
plantation, a casa-grande e a senzala, o apartheid e os movimentos de imigração contemporâneos, todas são experiências que provocam o desafio de entender os desdobramentos dos mecanismos de controle que tem a raça como principal marcador de diferença e a morte enquanto expressão máxima do poder soberano.

O desafio que é colocado à nossa frente, além de tudo que já foi posto, é continuar produzindo deslocamentos. Um convite para que sejam feitas novas questões perante as verdades universais, para que deste movimento surjam as bases para uma nova forma de existência no mundo.

Por isto o silêncio é também um chamamento.

É na tentativa de responder a este chamado que o conceito de necroarquitetura é aqui forjado. Pensar esta ideia aparece como uma maneira de implicar uma disciplina que, até então, se manteve afastada dos debates acerca da raça e dos processos de exploração colonial. Existe uma lacuna no discurso da arquitetura. Porém como vimos, são incontáveis os exemplos que demonstram o quanto os saberes e as práticas que tangem a ação e criação de ordenamentos espaciais estão implicados nos processos necropolíticos.

Aqui nos detivemos ao caso do Valongo, porém podemos olhar para outros territórios e encontrar ecos desta forma de produzir espaços. Espalhados ao longo do tempo e do globo terrestre, vemos emergir diversas estruturas espaciais dedicadas ao controle e a segregação de grupos racialmente subalternizados. Passando pelos bantustões em África, os bidonvilles franceses, não esquecendo o apartheid e as leis Jim Crow nos Estados Unidos e chegando nos campos de refugiados ao redor do planeta. A raça sempre foi utilizada como meio de produzir espaços distintos, carregados de elementos simbólicos e materiais, reproduzindo em todos os momentos as estratégias do necropoder.

Preocupados com a construção do mundo civilizado, os arquitetos deixaram do lado de fora de suas projeções uma infinidade de outros modos de vida que não se encaixam em seus padrões estéticos e morais. Sobre este assunto não vemos nada escrito na historiografia da arquitetura, inclusive nos debates mais críticos e engajados a questionar 
o status quo. Mesmo quando ainda não existiam arquitetos, exercendo a disciplina aos moldes do que temos hoje, no caso do período em que o Valongo foi produzido, já é possível perceber a técnica de construção e pensamento de espaços a serviço da morte.

É nesta fissura que a necroarquitetura se instala. Não para caracterizar uma antítese da Arquitetura, mas para revelar que somente a partir da criação de espaços de normatização da violência e gestão da morte é que tornou-se possível alimentar os ideais de uma arquitetura pretensamente humanista e universalista. A história da Arquitetura pode ser contada a partir de outros fenômenos, para que seja possível alcançar estes lugares menos iluminados. É preciso deflagrar o racismo existente na Arquitetura que, se não se manifesta enquanto ação, está presente na omissão. Esta necessidade de mudança é o que motiva o surgimento de novos conceitos, como o que aqui foi apresentado. Ideias que venham dar força a esses processos de construção e demolição de narrativas e práticas.

Precisamos criar um abrigo temporário em meio as ruínas deste mundo que se despedaça.

Por isso a urgência do silêncio.

Para tomar o fôlego necessário, e seguir contando novas histórias. 


\section{Referências bibliográficas}

ABREU, Maurício de Almeida. A evolução urbana no Rio de Janeiro. Rio de Janeiro: Iplanrio/Zahar, 1987.

ACOSTA-LEYVA, Pedro. Modalidades tradicionais africanas de captura para o tráfico negreiro. Revista África(s), v. 04, n. 08, p. 91-103, jul./dez. 2017.

As famílias nobres africanas no tráfico (1500-1850): O mito da captura. Revista África(s), v. 02, n. 03, p. 07-21, jan./jun. 2015.

ALGRANTI, Leila Mezan. O feitor ausente: estudo sobre a escravidão urbana no Rio de Janeiro, 1808 - 1821. Petrópolis, RJ: Editora Vozes, 1988.

ANDREATTA, Verena. Cidades quadradas, paraísos circulares: os planos urbanísticos do Rio de Janeiro no século XIX. Rio de Janeiro: Mauad, 2006.

AZEVEDO, Célia M. M. de. Onda negra, medo branco: o negro no imaginário das elites (século XIX). Rio de Janeiro: Paz e terra, 1987.

BANDEIRA, Julio \& CORRÊA DO LAGO. Pedro Debret e o Brasil Obra Completa - 1816 - 1831. Rio de Janeiro: Capivara, 2009.

BARREIRO, José C. Imaginário e viajantes no Brasil do século XIX: cultura e cotidiano, tradição e resistência. São Paulo: UNESP, 2002.

BATAILLE, Georges. Architecture. In Oeuvres complètes. Tomo I. Paris: Gallimard, 1970.

BERNARDES, Lysia Maria Cavalcanti. Evolução da Paisagem Urbana do Rio de Janeiro até o início do século $\mathbf{X X}$. Boletim Carioca de Geografia. Rio de Janeiro, no 1 e 2, 1959.

BICALHO, Maria Fernanda. A cidade e o Império: O Rio de Janeiro no século XVIII. Rio de Janeiro: Civilização Brasileira, 2003.

BRITO, Danilo Lopes. O Rio de Janeiro do século XVIII no olhar dos viajantes ingleses. 2006 Disponível em: <https://www.bn.gov.br/producao-intelectual/documentos/rio-janeiroseculo-xviii-olhar-viajantes>. Acesso em 16 mar. 2018. 
CAVALCANTI, Nireu Oliveira. A cidade de São Sebastião do Rio de Janeiro: As muralhas, sua gente, os construtores (1710 - 1810). Tese de Doutorado - Rio de Janeiro: UFRJ, 1997.

O Rio de Janeiro dos setecentos: A vida e a Construção da cidade da invasão francesa até a chegada da Corte. Rio de Janeiro: Jorge Zahar editor, 2004.

COARACY, Vivaldo. Memórias da cidade do Rio de Janeiro. Rio de Janeiro: José Olympio, 1955.

CONCEIÇÃO, Lívia Beatriz da. Soberania no Mundo Atlântico: Tráfico de escravos e a construção do Estado nacional no Brasil monárquico (1831 - 1850). Dissertação de Mestrado - Niterói - UFF, 2004.

CONRAD, Robert E. Tumbeiros - O tráfico escravista para o Brasil. São Paulo: Brasiliense, 1985.

Os últimos anos da escravatura no Brasil. Rio de Janeiro: Civilização Brasileira, 1978.

COSTA E SILVA, A. (1994). O Brasil, a África e o Atlântico no século XIX. Estudos Avançados, 8(21), 21-42.

Dossiê da candidatura do Cais do Valongo. 2016. Disponível em $<$ http://portal.iphan.gov.br/uploads/ckfinder/arquivos/Dossie_Cais_do_Val ongo_versao_Portugues.pdf>

FANON, Frantz. Os condenados da terra. Rio de Janeiro: Civilização Brasileira,1968.

Pele negra, máscaras brancas. Salvador: Edufba, 2008. 194

p.

FLORENTINO, Manolo. Em costas negras: uma história do tráfico de escravos entre a África e o Rio de Janeiro - séculos XVIII e XIX. São Paulo: Companhia das Letras, 1997.

FOUCAULT, Michel. "Aula de 17 de março de 1976" In:_. Em defesa da sociedade. São Paulo: Martins Fontes, 2005. p. 285-315.

. Ética, Sexualidade, Política. 2.ed. (Coleção Ditos e Escritos V). Rio de Janeiro: Forense Universitária, 2006b.

História da Sexualidade I: A Vontade de Saber. Rio de Janeiro, Edições Graal, 1977. 
História da Sexualidade 2: O Uso dos Prazeres. 5.ed. Rio de Janeiro, Edições Graal, 1984a.

. História da Sexualidade 3: O Cuidado de Si. Rio de Janeiro, Edições Graal, 1985.

Microfísica do Poder. 24.ed. São Paulo: Edições Graal, 2007a.

. Vigiar e Punir: Nascimento da Prisão. Petrópolis: Editora Vozes, 1987.

Segurança, Território, População. Curso dado no Collège de France, 1977-1978. São Paulo: Martins Fontes: 2008b.

O corpo utópico, as heterotopias. São Paulo: n-1 Edições, 2013.

HONORATO, Claudio de Paula. Valongo: O mercado de escravos do Rio de Janeiro, 1758-1831. 2008. 166 f. Dissertação (Mestrado) - Curso de História, Instituto de Ciências Humanas e Filosofia, Universidade Federal Fluminense, Niterói, 2008.

KARASCH, Mary C. A vida dos escravos no Rio de Janeiro (18081850). São Paulo: Companhia das Letras, 2000.

KILOMBA, Grada. The Mask. In: Plantation Memories: Episodes of Everyday Racism. Münster: Unrast Verlag, 2. Edição 2010.

KLEIN, Herbert S. O comércio Atlântico de Escravos: quatro séculos de comércio esclavagista. Lisboa: Editora Replicação Ltda., 2002.

LAMARÃO, Sérgio Tadeu de Niemeyer. Dos trapiches ao porto. Rio de Janeiro: Biblioteca Carioca, 1991.

LARA, Silvia Hunold. Campos da violência: escravos e senhores na capitania do Rio de Janeiro (1750-1808). Rio de Janeiro: Paz e Terra, 1988.

MBEMBE, Achille. Necropolítica, una revisión crítica. In GREGOR, Helena Chávez Mac (Org.). Estética y violencia: necropolítica, militarización y vidas Iloradas. Cidade do México: MUAC, 2012.

. Crítica da razão negra. 2. ed. Lisboa: Antígona, 2014.

Sair da grande noite: Ensaio sobre a África descolonizada.

Mangualde: Pedago, 2014. 
. Necropolítica. Arte \& Ensaios: Revista do Programa de PósGraduação em Artes Visuais EBA da UFRJ, Rio de Janeiro, n. 32, p.122151, dez. 2016. Semestral.

Políticas da inimizade. Lisboa: Antígona, 2017, p. 36. . Necropolítica. São Paulo, n-1, 2018.

NASCIMENTO, Abdias do. 0 genocídio do negro brasileiro: Processo de um Racismo Mascarado. 2. ed. São Paulo: Perspectiva, 2017. RODRIGUES, Jaime. 0 infame comércio - proposta e experiências no final do tráfico de africanos para o Brasil (1808 - 1850). Campinas: Unicamp, 2000.

. Os traficantes e seu 'infame comércio' (1827-1860). Revista Brasileira de História.15 (29), pp. 139-55. 1995.

. De costa a costa: escravos e tripulantes no tráfico negreiro (Angola - Rio de Janeiro, 1780-1860). Campinas, IFCH-UNICAMP, 2000. Tese de doutorado.

De Costa a Costa: Escravos, marinheiros e intermediários do tráfico negreiro de Angola ao Rio de Janeiro (1780-1860). São Paulo: Companhia das Letras, 2005.

. Festa na chegada: O tráfico e o mercado de escravos do Rio de Janeiro. In SCHUARCZ, Lilia Moritz e REIS, Letícia Vidor de Sousa. Negras Imagens: Ensaios sobre cultura e escravidão no Brasil. São Paulo: Edusp, 1996.

SANTOS, Francisco Noronha. As freguesias do Rio antigo. Rio de Janeiro: Ed. O Cruzeiro, 1965.

SANTOS, Renato Emerson dos (Org.). Questões urbanas e racismo. Petrópolis, RJ: DP et Alii; Brasília, DF: ABPN, 2012.

SOARES, C. E. L. A copeira escrava e ouras tradições rebeldes no Rio de Janeiro (1808-1850). Editora Unicamp: Campinas SP: 2001. Zungú: rumor de muitas vozes. Rio de Janeiro: Arquivo Público do Estado do Rio de Janeiro, 1998. 


\section{Relatos de Viagem}

DEBRET. J. B. Viagem Pitoresca e histórica ao Brasil. São Paulo. Círculo do Livro S.A. Tradução cedida para o Circulo do Livro S.A. por cortesia da Livraria Martins Editora S.A.

ENDER, Thomas. Viagem ao Brasil nas aquarelas de Thomas Ender. Apresentada por Robert Wagner e Julio Bandeira. Petrópolis/RJ: Kapa, 2000.

FREIRYSS, Georg W. Viagem ao interior do Brasil nos anos de 18141815. Trad. Alberto Löfren. São Paulo: 1906.

GRAHAM, Maria D. Diário de uma viagem ao Brasil e de uma estada nesse país durante os anos de 1821, 1822 e 1823. São Paulo: Cia Ed. Nacional, 1956.

LUCCOCK, John. Notas sobre o Rio de Janeiro e partes meridionais do Brasil. São Paulo/Edusp; Belo Horizonte: Itatiaia, 1975.

RIBEYROLLES, Charles. Brasil Pitoresco. Trad. Gastão Penalva. Belo Horizonte/São Paulo: Itatiaia/Edusp, 1975, vol. 1.

RUGENDAS, Johann M. Viagem pitoresca através do Brasil. São Paulo: Edusp/Martins, 1972.

SCHICHTHORST, C. O Rio de Janeiro como é (1824-1825). Senado Federal - Brasília - 2000.

SPIX. Johann Baptist von \& MARTIUS, Carl Friedrich Philip von. Viagem pelo Brasil, 2 volumes. Primeira edição em alemão - 1823 - tradução de Lucia Furquim. 